Portland State University

PDXScholar

$1-1-1973$

\title{
Aspects of the physiology and diseases of the North American elk
}

Yvonne Bernard Weber

Portland State University

Follow this and additional works at: https://pdxscholar.library.pdx.edu/open_access_etds

\section{Let us know how access to this document benefits you.}

\section{Recommended Citation}

Weber, Yvonne Bernard, "Aspects of the physiology and diseases of the North American elk" (1973). Dissertations and Theses. Paper 860.

https://doi.org/10.15760/etd.860

This Dissertation is brought to you for free and open access. It has been accepted for inclusion in Dissertations and Theses by an authorized administrator of PDXScholar. Please contact us if we can make this document more accessible: pdxscholar@pdx.edu. 


\title{
ASPECTS OF THE PHYSIOLOGY AND DISEASES \\ OF THE NORTH AMERICAN ELK
}

by

YVONNE BERNARD WEBER

\author{
A thesis submitted in partial fulfillment of the \\ requirements for the degree of \\ DOCTOR OF PHILOSOPHY \\ in \\ ENVIRONMENTAL SCIENCES AND RESOURCES - BIOLOGY
}

Portland State University

1973 
TO THE OFFICE OF GRADUATE STUDIES AND RESEARCH:

The members of the Committee approve the thesis of

Yvonne B. Weber presented May 31, 1973.

Defvid T. Clark, Chairmain

Richard Forbes

Denzel Fergetso

Elaine Spencer

APPROVED:

Earl Fishor, Jr., Head, Department of Blology

Bavid I. Clark, Dean of Graduate Studies 
AN ABSTRACT OF THE THESIS OF Yvonne B. Veber for the Doctor of Philosophy in Environmental Sciences and Resources - Biology presented on May 31, 1973.

Title: Aspects of the Physiology and Diseases of the North American E1k

APPROVED BY MEMBERS OF THE THESIS COMMETTEE:

Daffd T. Clark, Chairman

Richard Forbes

Denzel Ferguson c

Elaine Spencer

Ex-officio:

Dr. Earl Fisher, Biology Iepartment 
Several aspects of the physiology and diseases of the North American elk (Cervus canadensis) were investigated, toward the goal of uncovering Influences responsible for declining productivity among some elk herds in Oregon.

A newly developed drug, Etorphine, together with its antagonistic companion, Diprenorphine, was used to immobilize elk. Substantial differences were found in the amounts required and animal responses dependent upon age, physical condition and life history.

Whole blood samples were obtained from 60 living elk for hematological studies. The parameters examined included hemoglobin levels, packed cell volume, erythrocyte and leukocyte counts, mean corpuscular hemoglobin, mean corpuscular hemoglobin concentration, mean corpuscular volume, and the percentage distribution of neutrophils, band cells, lymphocytes, monocytes, eosinophils, and basophils. Respiration rate, heart rate, and body temperature were measured for nine drugged elk. Sickling of erythrouytes was found in the blood of two female elk. Serum was separated from the blood of 72 living elk and 22 recently shot eik oí mixed ages and sexes. Seruim protefns were differentiated by electrophoretic analysis. Values obtained for total protein, albumin, total globulin, albumin/globulin ratio, and for the alpha alpha 2 , beta and gamma globulins, were grouped and summarized to facilitate comparisons based on age and sex, as well as between living and dead, and captive and free-living elk. Total serum protein concentrations were markedly higher in the older age groups of both captive and freeliving elk. An apparent tendency to higher albumin levels was found 
among males of this species.

Values for serum concentrations of sodium, potassium, calcium, inorganic phosphorus, blood urea nitrogen, chlorides, cholesterol, glucose, direct bilirubin, total bilirubin, creatinine, and uric acid, as well as activity levels of alkaline phosphatase, lactic dehydrogenase, and serum glutamic oxalacetic transaminase were obtained. Sodium/ potassium and calcium/phosphorus ratios were calculated. Urine speciments were obtained from seven elk and analyzed for the presence of glucose. Young elk, both captive and free-living, had higher serum values for sodium, calcium, inorganic phosphorus, glucose and alkaline phosphatase than did the older age group. Mature elk, both captive and free-living, had higher serum values for calcium/phosphorus ratio, blood urea nitrogen, creatinine, uric acid and serum glutamic oxalacetic transaminase than did those under two years of age. Differences in serum chemistry were also found between captive and free-living elk. Serological tests on sera from $67 \mathrm{elk}$ tested were negative for brucellosis and bluetongue virus. Tests for leptospirosis on sera from 29 elk by the macroscopic agglutination method were all negative. of 38 free-living elk tested for leptospirosis by the microscopic agglutination test, 16 showed positive reactions to one or more serotypes at a significant titer of 1:100 or greater. Another eight showed positive reactions at the 1:50 level. This is believed to the first report of serological reactivity to leptospirosis reported for elk.

Internal organs from 39 elk were examined for the presence of adult helminths, and fecal pellets from 82 elk were examined for the presence of parasite eggs. Lethal numbers of Dictyocaulus viviparus 
were recovered from the respizistory organs of two yearling male elk. Two nematodes of the infian, Trichostrongylus axei and Ostertagia circumcincta, were foum that have not been previously reported from Roosevelt elk. Fascic oideg magna and Desoptagostomum venulosum were also found.

The common winter tick, Dermacentor albipictus and Ixodes pacificus were collected fren $Y a s s e v e l t$ elk. This latter epecies has not been previously reported in elk. Increased gamma globulin values and concomitant decreases in albumin were observed in tick-infested elk. 


\section{ACKNOWLEDGEMENTS}

With gratitude, I acknowledge my indebtedness to the many people who helped with this study; however, space does not permit me to name them al1. Dr. David Clark, my thesis advisor, and Dr. Richard Forbes, my major field advisor, were a never-failing source of counsel and encouragement. Dr. Elaine Spencer gave invaluable guidance with biochemistry, as did Dr. Quentin Clarkson with statistics. Experience in wildlife investigational techniques was provided by. Dr. Richard Knight, University of Idaho, and Dr. Robert Ream, University of Montana.

Access to free-living elk was made possible through the cooperation of the Oregon State Game Commission. I particularly wish to thank Messrs. Victor Coggins, Paul Ebert, William Hall, James Harper, Robert Mace, and Richard Pedersen for their assistance. Access to captive elk was made possible by the management and personnel of the Portland Zoological Gardens, Point Defiance Zoological Park, and Woodland Park Zoological Gardens, whose interest and help are appreciated.

Direct financial support was given by the National Wildlife Federation, the College of Science, Portland State University, and the Oregon Zoological Research Center. The latter institution, directed by Dr. Luigi Giacometti, also provided research facilities, 1aboratory equipment, and technical aid.

The patience and understanding of my husband and children has been a never-ending source of inspiration. 
TABLE OF CONTENTS

PAGE

ACKNOWLEDGMENTS $\ldots \ldots \ldots \ldots \ldots \ldots \ldots \ldots \ldots \ldots \ldots \ldots \ldots \ldots \ldots \ldots \ldots \ldots$ ii

LIST OF TABLES $\ldots \ldots \ldots \ldots \ldots \ldots \ldots \ldots \ldots \ldots \ldots \ldots \ldots \ldots \ldots \ldots \ldots \ldots$ v

LIST OF FIGURES $\ldots \ldots \ldots \ldots \ldots \ldots \ldots \ldots \ldots \ldots \ldots \ldots \ldots \ldots \ldots \ldots \ldots \ldots$

CHAPTER

I INTRODUCTION............................. 1

II IMMOBILIZING TECHNIQUES..................... 14

III HEMATOLOGY............................. 25

IV SICKLING IN ELK........................ 45

V SERUM PROTEINS.......................... 50

VI SERUM CHEMISTRY......................... 71

VII VIRAL AND BACTERIAL DISEASES................ 107

VIII HELMINTHIC DISEASES..................... 118

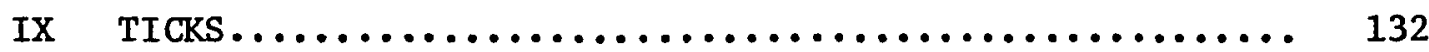

REFERENCES..................................... 139

APPENDIX A. .................................. 159

APPENDIX в................................... 160

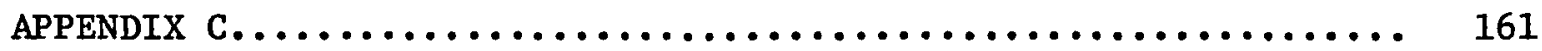




\section{LIST OF TABLES}

TABLE

I Basic Diet of Captive Elk.................... 11

II The Origin of Eighty-two Living Elk Studied.......... 13

III Dosage, Induction and Recovery Data for Free-Living

Female Adult Elk........................... 18

IV Dosage, Induction and Recovery Data for Free-Living

Female Yearling Elk........................... 19

V Dosage, Induction and Recovery Data for Free-Living

Male Yearling Elk........................... 20

VI Comparison of Use Characteristics of Etorphine and

Succinylcholine Chloride...................... 22

VII Whole Blood Values for Free-Living and Captive Elk

With Statistical Description................... 28

VIII Some Physiological Responses of Captive Elk (Drugged)

and Free-Living Elk (Squeeze Chute)................ 30

IX Hematological Values for Elk from Three Areas of the

Western United States........................... 33

X Summary of Hematological Values for Two Age Groups

of Captive Elk............................. 34

XI Summary of Hematological Values for Two Age Groups

of Free-Living E1k.......................... 35

XII Summary of Serum Protein Values for Dead and Living

E1k.................................. 57

XIII Summary of Serum Globulin Values for Dead and Living

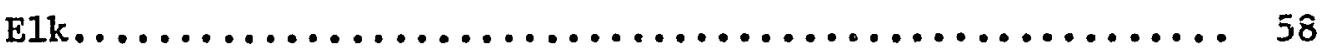


XIV Albumin (g\%) Concentrations for Male and Female Elk.....

XV Summary of Serum Protein Values for Two Age Groups

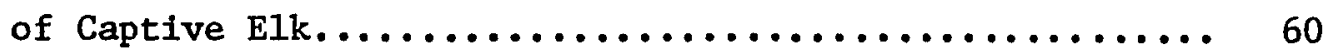

XVI Summary of Serum Protein Values for Two Age Groups of Free-Living Elk.......................... 61

XVII Mean Values for Serum Proteins for Six Categories of

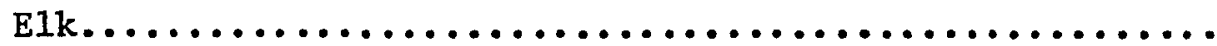

XVIII Summary of Values for Three Serum Minerals in Dead and Living Elk...........................

XVIX Summary of Values for Three Serum Minerals in Dead and Living Elk........................... 76

XX Summary of Values for Four Serum Components in Dead

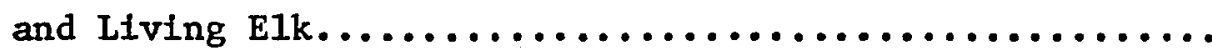

XXI Summary of Values for Four Serum Metabolic By-products in Dead and Living Elk..................... 78

XXII Summary of Activity Levels for Three Serum Enzymes in Dead and Living Elk....................... 79

XXIII Influence of Lactation on Serum Glucose (mg\%)

Concentrations............................ 80

XXIV Summary of Serum Mineral Values for Two Age Groups

of Captive Elk...........................

XXV Summary of Serum Mineral Values for Two Age Groups of Captive Elk.............................

XXVI Summary of Values for Serum Components for Two Age Groups of Captive Elk....................... 
XXVII Summary of Values for Serum Metabolic By-products

for Two Age Groups of Captive Elk................. 84

XXVIII Summary of Levels of Serum Enzyme Activity for Two

Age Groups of Captive Elk................... 85

XXIX Summary of Serum Mineral Values for Two Age Groups of

Free-living Elk.......................... 86

XXX Summary of Serum Mineral Values for Two Age Groups of

Free-living Elk...........................

XXXI Summary of Values for Serum Components for Two Age

Groups of Free-living Elk.................... 88

XXXII Summary of Values for Serum Metabolic By-products for

Two Age Groups of Free-living Elk................ 89

XXXIII Summary of Levels of Serum Enzyme Activity for Two Age

Groups of Free-11ving E1k.................... 90

XXXIV Means of Al1 Seventeen Parameters for Six Categories

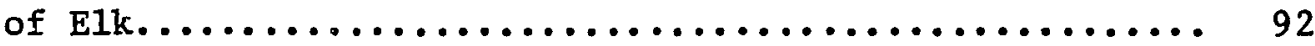

XXXV Summary of Antibody Titers to Specific Leptospiral

Serotypes Among 38 Samples of Elk Serum............ 113

XXXVI Serotype, Sex and Age Data for E1k with Positive

Agglutination Titers of $1: 100$ or Higher........... 116

XXXVII Total numbers of Abomasal Parasites Recovered from

37 Roosevelt Elk Examined........................... 124

XXXVIII Species and Percentages of Abomasal Nematodes found

in 37 Roosevelt E1k.......................... 125 
viii

TABLE

PAGE

XXXIX Ticks from Free-living Roosevelt Elk.............. 135

XL Serum Protein Values of Tick-infested Roosevelt

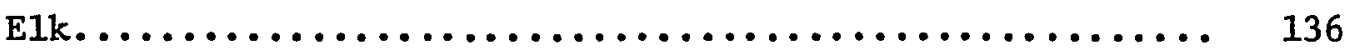




\section{LIST OF FIGURES}

FIGURE

PAGE

1 Counties in Oregon from which Samples were Obtained

from Free-living Elk....................... 4

2 Sites of Elk Traps in Southwestern Oregon............ 6

3 Clatsop County, Oregon, with Site of Jewell Wildiffe

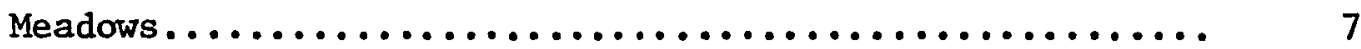

4 Sites of E1k Traps in Wallowa County, Oregon........... 8

5 Sites of Elk Traps in Umat11la County, Oregon.......... 9

6 Familial Relationships of the Three Captive Elk Herds... 10

6A Frequency Distribution Plots of Hemoglobin Values....... 29

6B Frequency Distribution Plots of Mean Corpuscular

Hemoglobin Values..........................

6C Frequency Distribution Plots of Mean Corpuscular

Volume Values.............................

6D Frequency Distribution Plots of Physiological

Responses of Drugged Elk...................... 32

бEE Frequency Distribution Plots of Hematological Values

for Two Age Groups of Captive Elk................ 36

6F Frequency Distribution Plots of Hematological Values

for Two Age Groups of Free-l1ving E1k..............

7 Photomicrographs of Blood from Two Elk Showing Sickled

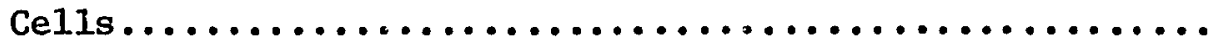




\section{CHAPTER I}

\section{INTRODUCTION}

A remarkable evolution in human attitudes toward wild animals has occurred during the past half century. A new environmental ethic is emerging which acknowledges the importance of maintaining a rich and varied fauna of wild creatures in wild habitats. This growing concern for wildife conservation manifests itself in management intended to provide sufficient numbers of animals for three major purposes: to serve as a crop to be harvested by hunting; to provide visual enjoyment for a society with increasing time for travel and outdoor recreation; and, to prevent the extinction of a species or subspecies having habitat needs that bring it into conflict with man. The North American elk, Cervus canadensis, in different parts of its present range, is included in each of these categories.

According to a recent census conducted by the Oregon State Game Commission (personal communication of 8 March 1973 from R. R. Mabin, Game Management Brach, Portland, Oregon), Oregon has an estimated 82,000 elk, of which 37,000 are the west coast or Roosevelt subspecies, Cervus canadensis roosevelti Merriam 1897, and 45,000 are the inland or Rocky Mountain form, Cervus canadensis nelsoni Bailey 1935.

Roosevelt elk, the largest and darkest subspecies, are distributed discontinuously from Humboldt and Del Norte countles in northwestern California northward, through western Oregon, western Washington and British Columbia. Major population centers occur on the 0lympic Peninsula and on Vancouver Island. Ari iuiroduced herd is thriving on 
Afognak Island, Alaska, where males welghing 1,400 pounds have been reported (Troyer 1960). Scattered herds of Roosevelt $\in 1 k$ are found throughout Oregon's Coast and Cascade Mountains. The largest concentrations sre found in Tillamook, Clatsop and Coos counties (Mace 1971).

E1k of the Rocky Mountain subspecies are distributed in Oregon throughout the Blue and Wallowa Mountains, ranging southward into Malheur and Harney counties and westward into Jefferson and Crook counties. Elevations above 5,000 feet are preferred during the summer months. Niviement to such range begins as soon as weather conditions permit in the spring. Mountain meadows with conventent access to water and cover are favored areas of summertime concentration (Mace 1971). Along the crest of the Cascade Range in Washington, members of the Roosevelt and Rocky Mountains subspecies meet and probably intergrade. Before Rocky Mountain elk were introduced into the Yakima Valley, the two subspecies were separated by a sizeable expanse of unoccupied territory (Murie 1951b). E1k are less numerous in the Cascade Mountains and little natural population increase is evident there. Scattered herds are found on the east slopes of Mount Hood and in the upper drainages of the Breitenbush, McKenzle, Clackamas, Rogue and Willamette rivers. Summer distribution extends to the crest of the Cascades. During winter, both slopes are occupied by Roosevelt elk, with the west side of the Cascades being preferred (Mace 1971).

Human settlement encroaching on original elk range, accompanied by unrestricted hunting, severely reduced Oregon's elk numbers by the turn of the century (Mace 1971). Between 1905 and 1933, elk hunting 
was prohibited in Oregon to allow remant bands to rebuild their numbers. Estimates of total numbers of elk in Oregon increased from 7,351 in 1932 to 23,345 in 1933 (Bailey 1936:79). In recent years, considerable trapping and transplanting of elk has been done by the Oregon State Game Commission. Trapping and transplanting are especially satisfactory management techniques wherever elk numbers exceed habitat limitations or create conflicts on agricultural lands (Mace 1971).

Management of wild species has, in the past, relied on various kinds of gross and empirical knowledge. The time has arrived for more sophisticated techniques of field and laboratory study to supplement the procedures of the past. This study employs some recent techniques as tools for the investigation of some aspects of the physiology and diseases of North American elk. Greater knowledge of these features of elk life history should benefit those who have responsibility for the management of either captive or free-living elk.

Chapters II through IX of this thesis deal with different aspects of the physiology and diseases of Cervus canadensis. For each area of investigation, it has been necessary to become familiar with a different field of literature and to follow spectalized methods applicable to the work. Therefore, the findings of others, the specific procedures followed, results, and conclusions will be discussed within appropriate chapters. Some general procedures, however, may conveniently be stated here.

With the help of the Oregon State Game Commission (OSGC), material used in this study was obtained from elk in the counties indicated in Figure 1. The management practice of live-trapping elk for transplant 


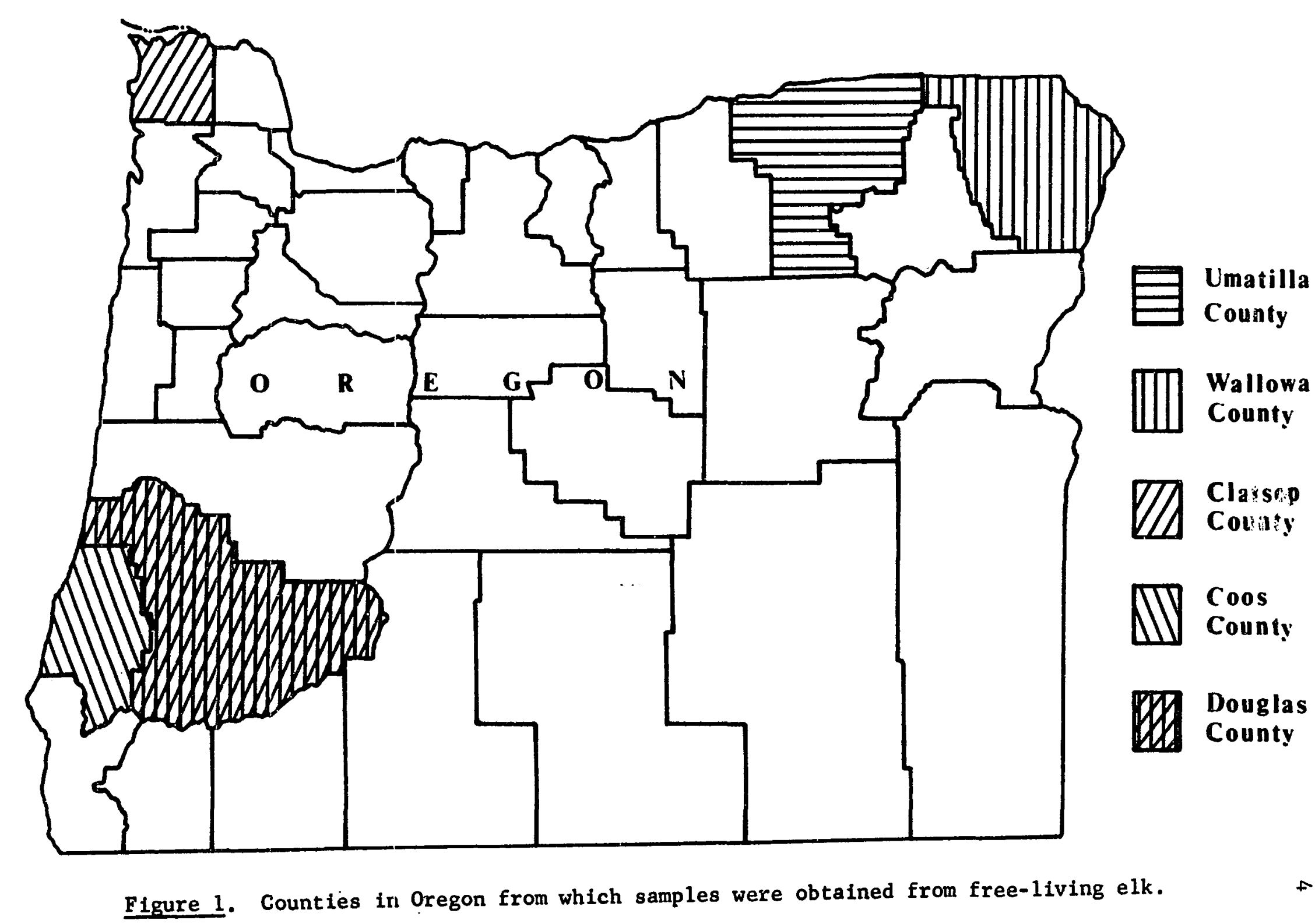


provided the opportunity to obtain blood and fecal samples and other data from free-living animals. The Roosevelt elk used in this study were live-trapped by OSGC in Douglas and Coos counties during January, February and March, 1971, at the sites indicated in Figure 2. The Rocky Mountain elk used in this study were live-trapped by OSGC in Umatilla and Wallowa counties during the summer months of 1971 and 1972 at the sites shown in Figures 4 and 5. Supplies and Instruction sheets were provided to the personnel who assisted me with this project. Appendix $A$ describes the procedure to be followed in drawing blood from live elk.

Samples from hunter-killed Roosevelt elk were obtained in Clatsop county through the assistance of the manager of the Jewell Wildlife Meadows, the location of which is snown in Figure 3. Appendix B outlines the recommended steps for obtaining internal organs from hunterkilled Roosevelt elk in Coos and Clatsop countles.

Blood was obtained and serum prepared by OSGC personnel from 22 hunter-killed Roosevelt elk.

Through the assistance of the officials and personnel involved, captive elk in zoological gardens of Washington and Oregon were made available for this study. The familial relationships are diagrammed in Figure 6 for the eleven elk of the Portland Zoological Gardens, the nine elk of the Woodland Park Zoological Gardens, Seattle, Washington, and the five elk of the Point Defiance Zoological Park, Tacoma, Washington. In accordance with preferred practices in zoo husbandry, captive elk are maintained on a diet as close as is practicable to that given in Table I, with water available ad libitum. 


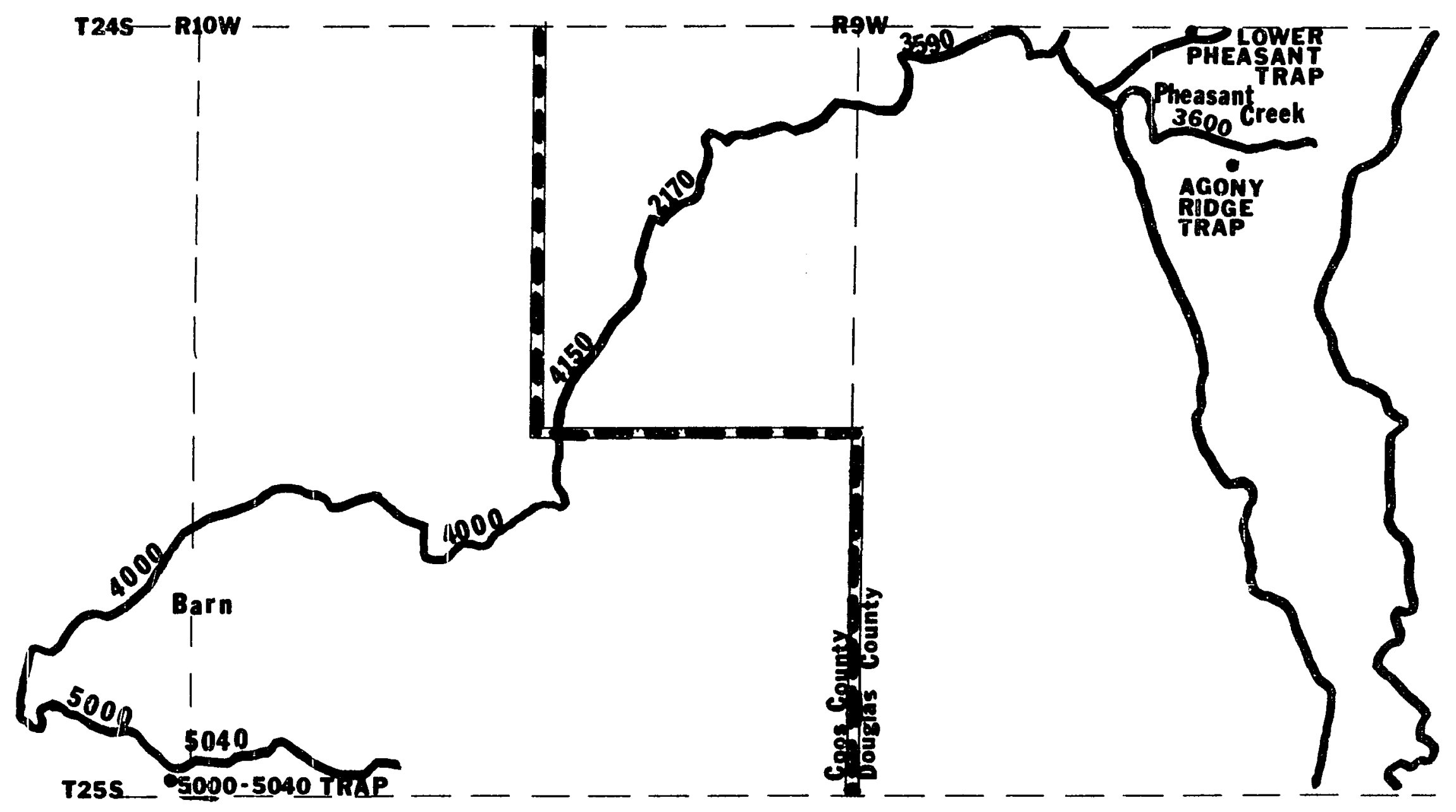

Figure 2. Sites of elk traps in southwestern Oregon. 


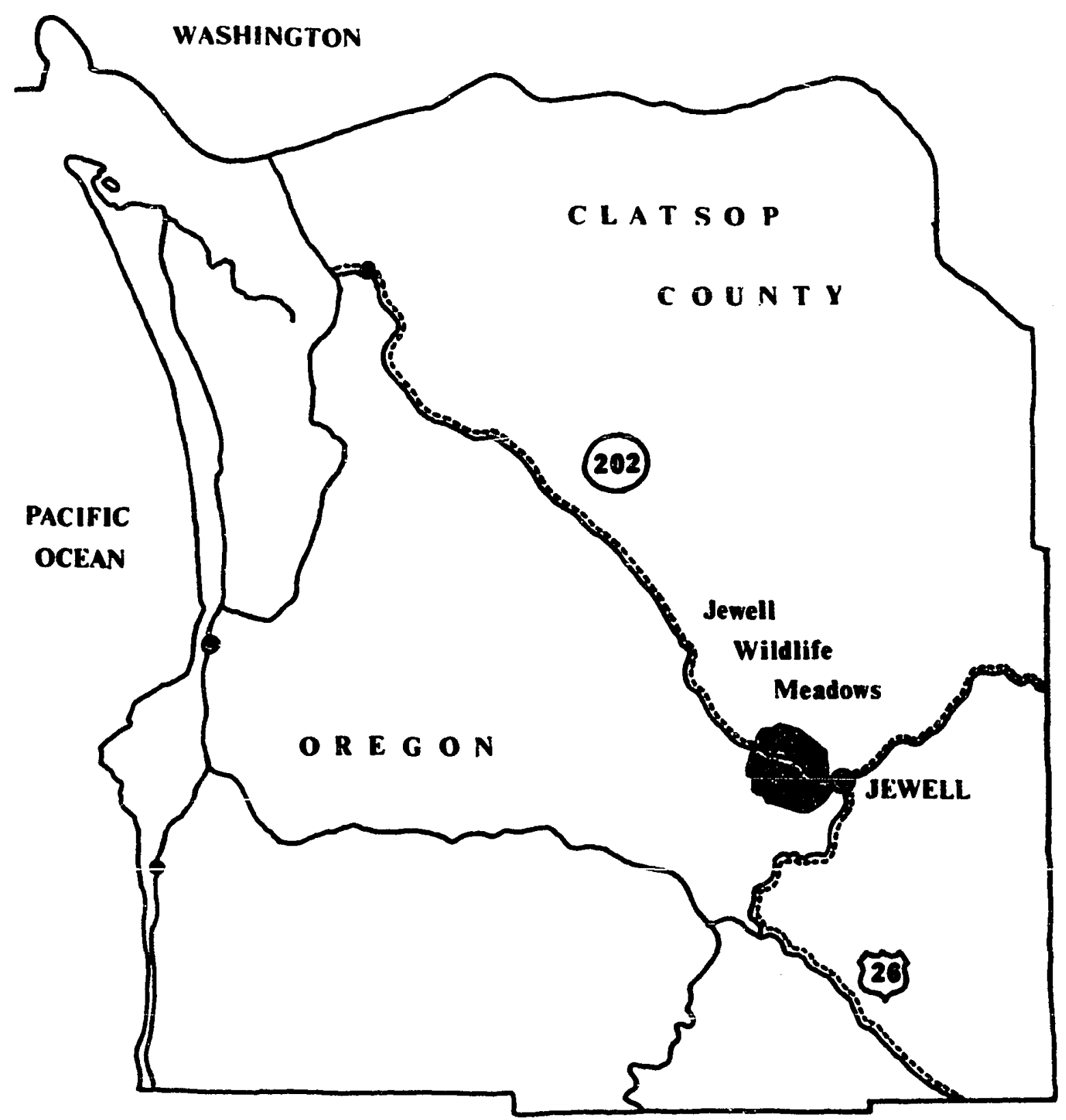

Pigure 3. Clatsop County, Oregon, with site of Jewell Wildilfe Meadows. 


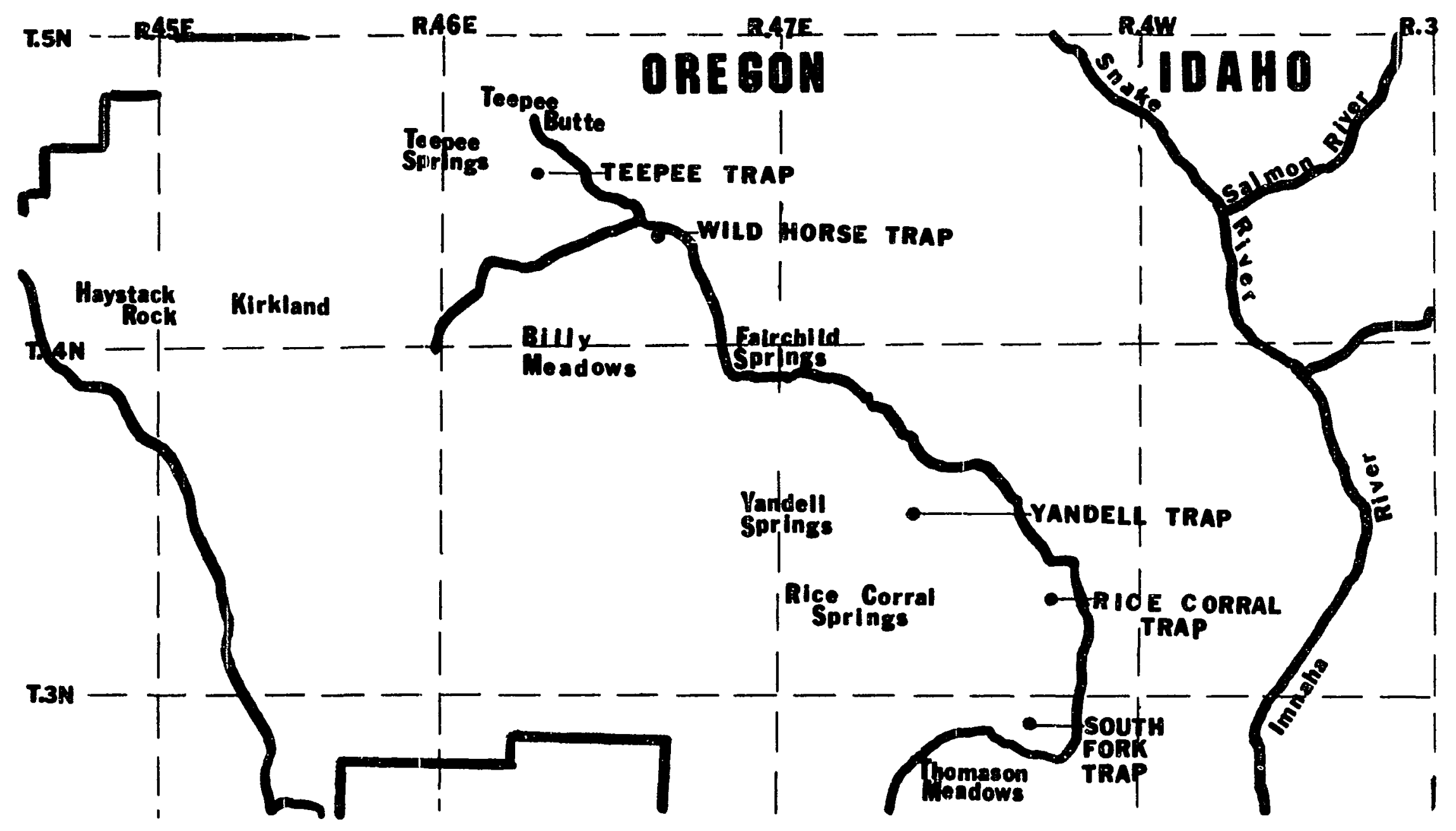

Figure 4. Sites of elk traps in Wallowa County, Oregon. 

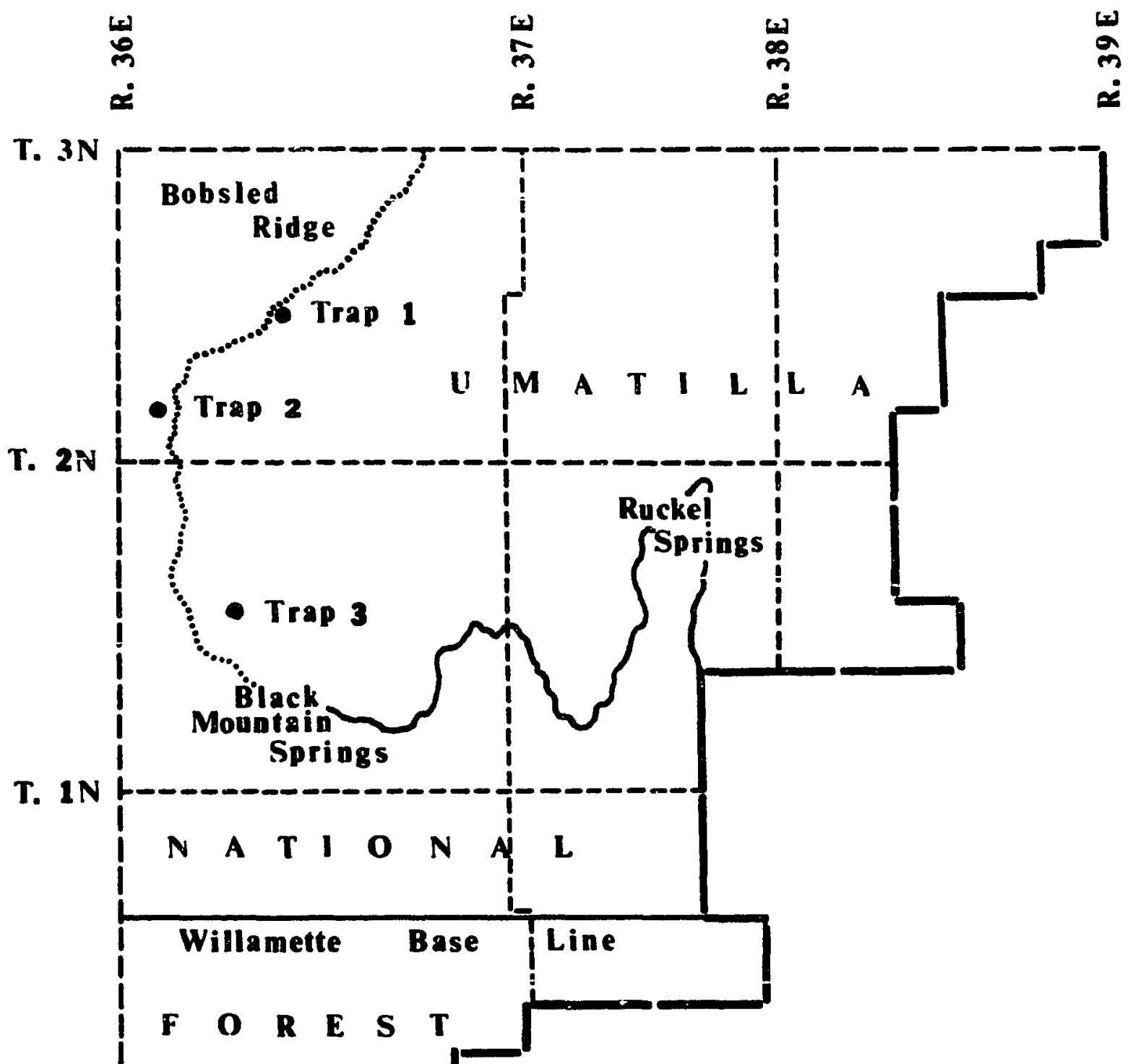

T. 15

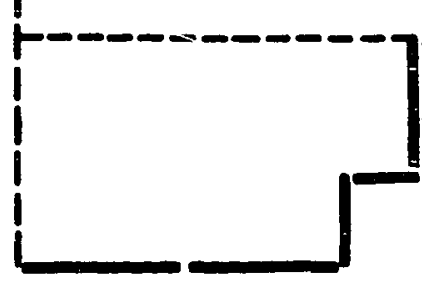

Figure 5. Sites of elk traps in Umatilla County, Oregon. 


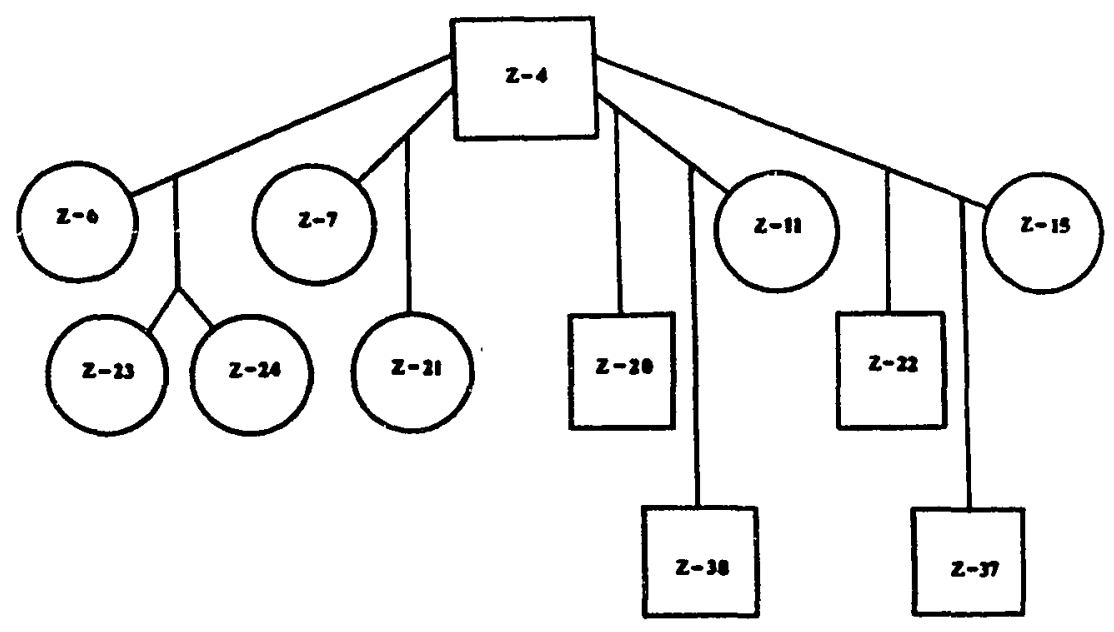

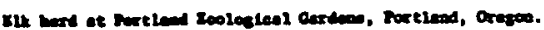
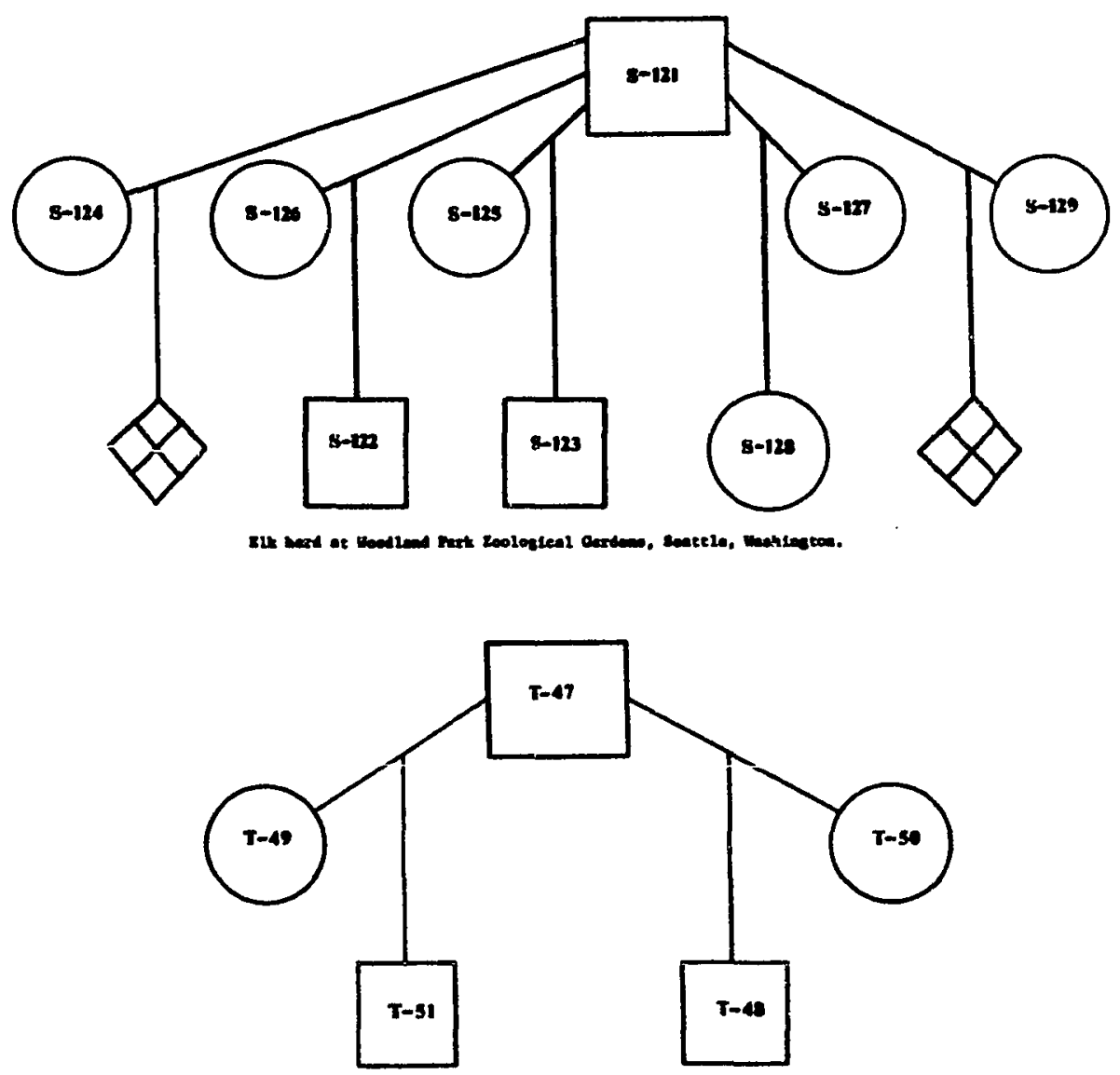

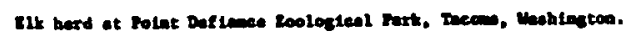

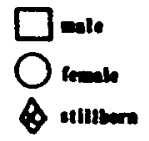

Figure 6. Familial relationships of the three captive elk herds. 
TABLE I

BASIC DIET OF CAPTIVE ELK

\section{Alfalfa}

Browse, when available

clippings, trimmings from trees, etc.

\section{Carrots}

\section{Dairy Chow*}

Guaranteed analysis :

crude protein, not less than ..... $12.50 \%$

crude fat . . . . . . . . . . $3.00 \%$

crude fiber, not more than ...... $10.00 \%$

ash, not more than .......... $9.00 \%$

moisture, not more than . . . . . . $12.00 \%$

Ingredients:

$$
\begin{aligned}
& \text { steam rolled corn } \\
& \text { steam rolled barley } \\
& \text { steam rolled oats } \\
& \text { cottonseed meal } \\
& \text { linseed oil meal } \\
& \text { beet pulp } \\
& \text { molasses }
\end{aligned}
$$

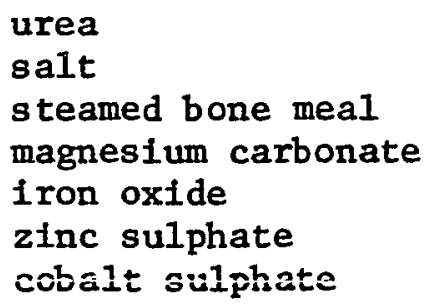

Greens, when available

* Manufactured by Burdic Feed Mil1, Rallroad \& E. Smith Streets, Kent, Washington 
The numbers and sources of all living elk from which samples were obtained for this study are summarized in Table II. The majority of the data obtained from this study, and presented in Chapters II through IX, were grouped for statistical description and the following statistics calculated: mean, variance, standard deviation (SD), standard error of the mean (SE), range, and size of sample ( $n$ ). In those cases where it is of aid in making a comparison with another author's work, the $95 \%$ confidence interval is given. Investigators who wish access to the original data of this study may contact the author through Portland State University. 
THE ORIGIN OF EIGHTY-TWO LIVING

ELK STUDIED

Captive $(\mathrm{n}=26)$

Point Defiance Zoological Park

Tacoma, Washington

February and March, 1972

Adults 3

Calves 2

Sub total

Portland Zoological Gardens

Portland, Oregon

Adults 5

All times of the year; 1970 through 1972

Calves 7

Subtotal

12

Woodland Park Zoological Gardens

Seattle, Washington

Adults 6

September, 1972

Calves $\underline{3}$

Sub total

9

Free-ranging $(n=56)$

Chesnimnus Unit

Wallowa County, Oregon

Yearlings 20

Adults 18

June and July, 1972

Sub total

促IIfcoma Tree Tasm

Yearlings 2

Adults $\underline{5}$

January, February and March, 1971

Subtotal

Umatilla County

Oregon

Yearlings $\quad 4$

Adults 7

July, August and September, 1971

Sub total

$\underline{11}$

TOTAL 
CHAPTER II

IMMOBILIZING TECHNIQUES

Techniques and products to tranquilize and immobilize wild animals have been the subject of extensive recent research. Lanphear (1962) summarized the effects of various immobilizing agents on wild ruminants imported into the United States. The Wildlife Monograph by Harthoorn (1965) is a definitive and extensive discussion of the use of drugs on wild mammals. Although Harthoorn's examples are largely drawn from his experience with African ungulates, the pharmacological and physiological principles are of value to anyone involved in similar work. King and Klingel (1965) described the use of M 99 Etorphine in immobilization procedures and the antagonism of M 99 with the related compound M 285 Cyprenorphine.

In his ecological study of the Roosevelt elk, Harper (1966) employed the drug succinylcholine chloride. White (1967) described a device for administering succinylcholine chloride to trapped deer, and compared that substance with nicotine alkaloids. Giles (1969) drew upon the data of many investigators in reviewing the products and dosages which have been found effective for immobilizing wildlife species. Fujita (1970) described the dangers of delayed hypersensitivity reaction to succinylcholine chloride among human patients.

Houston (1970) described $90 \%$ successful use of M 99 on 38 Shiras moose in Jackson Hole, Wyoming. Franzmann (1971) used M 99 to immobilize both captive and free-ranging bighorn sheep. Dean et al. (1973) found the drug Vesprin useful as an auxiliary tranquilizer in combination with 
phencyclidine hydrochloride.

METHODS AND MATERIALS

Initially, some of the elk for this study were immobilized with succinylcholine chloride ("Sucostrin", E. R. Squibb and Sons, New York, N. Y., $20 \mathrm{mg} / \mathrm{cc}$ ). Later, the majority were immobllized with Etorphine ("M 99", American Cyanamid Company, Princeton, New Jersey, $1 \mathrm{mg} / \mathrm{cc}$ ), either alone or in combination with the tranquilizing drug, triflupromazine hydrochloride, ("Vesprin", E. R. Squibb and Sons, New York, N. Y., $20 \mathrm{mg} / \mathrm{cc}$ ), administered intramuscularly.

Etorphine, 6:14-endoetheno-7-alpha (2-hydroxy-2-penty1)-tetrahydro oripavine hydrochloride, is a thebaine derivative chemically related to morphine. This drug, a narcotic, has the advantage of a high therapeutic index, the ratio of lethal dose to effective dose, which allows wide latitude in bodyweight estimations of wild animals (King and Klingel 1965). Primarily for this reason, it was selected as the drug of choice for my study.

The companion and antagonistic drug, Diprenorphine, ("M 50-50", American Cyanamid Company, Princeton, New Jersey, $2 \mathrm{mg} / \mathrm{cc}$ ), was administered intravenously to effect recovery from Etorphine. Diprenorphine, N-cycloprapy 1methy 1-7-alpha(1-hydroxy-1-methylethy 1 ) -6, 7, 8, 14-tetrahydro6,14-endoethano-noripavine hydrochloride, is also a thebaine derivative. Etorphine and Diprenorphine are both experimental compounds for which the U. S. Food and Drug Administration is compiling tissue residue data, and for which field test reports providing the details of dosage requirements and response characteristics are requỉred by stgned agreement 
(letter dated 25 February 1971 from B. T. Alford, D.V.M., Special Projects Manager, Agricultural Division, American Cyanamid Company, Princeton, N. J.).

Drugs for restraint were usually administered in 1 to $7 \mathrm{cc}$ automatic projectile syringes (darts) from a $\mathrm{CO}_{2}$ powered Cap-chur gun (Palmer Chemical and Equipment Company, Inc., Douglasville, Georgia). The elk were shot with drug-iilied darts while in traps or zoo enclosures at distances of about 10 yards. Another technique was followed with the nine elk at the Woodland Park Zoo. The drug-filled syringe was attached to a IIghtweight metal rod and injection was accomplished by approaching each animal closely enough to make contact with a thrusting motion of the rod. Injections of $M 99$ were made in the large muscles of the hindquarters of most animals.

Free-living elk were classed as yearling cows, adult cows, and yearling bulls, and the drug dosages were prepared accordingly. Weight data was not avallable.

Eighteen adult cows were given $6.5 \mathrm{mg}$ (mean) of $\mathrm{M} 99$; induction time (time from injection until the animal was immobilized) ranged from 10 to 34 minutes (mean: 21 minutes). The antagonist, M 50-50, was given at twice the M 99 dosage but the two drugs were administered in equal volumes because of the difference in concentrations. The cows were given $13 \mathrm{mg}$ (mean) of M 50-50 and recovery was complete in 1.1 minutes (mean). Sixteen yearling cows were given $4 \mathrm{mg}$ (mean) of M 99; induction time ranged from 3 to 28 minutes (mean: 14 minutes). The animals were given $7.9 \mathrm{mg}$ (mean) of $\mathrm{M} 50-50$ and recovery was complete in 1.6 minutes (mean). 
Eighteen yearling bulls were given $4.7 \mathrm{mg}$ (mean) of M 99 ; induction time ranged from 6 to 38 minutes (mean: 12.6 minutes). The animals were given $8.3 \mathrm{mg}$ (mean) of $\mathrm{M} \mathrm{50-50}$ and recovery was complete in 1.1 minutes (mean).

Calves (not included in the tables) received various amounts of drug, based largely on estimates of body welght.

RESULTS

See Tables III, IV and $V$ for a review of the dosage, induction time and recovery data for 52 free-living Rocky Mountain elk immobilized with M 99 during this study. Adult cows required a larger amount of M 99 for immobilization than did yearling males and females. It was necessary to increase by $1 \mathrm{cc}$ the quantity of M 99 given to both male and female yearlings between early June and early July.

The youngest elk included in this study were three-week-old captive calves, Z-37 and Z-38 (Figure 6), for which $.75 \mathrm{mg}$ of $M 99$ was an effective dose. When these two calves were 7 months old and weighed about 320 and 280 pounds, respectively, 2 mg of M 99 were administered to each. Induction time was 5 minutes for the heavier calf, and $4 \frac{1}{2}$ minutes for the smaller elk.

Three calves were immobilized at the Woodland Park Zoo (Figure 6). Effective quantities of M 99 for each were: $1 \mathrm{mg}$ for three-month-old S-122 (induction time, $4 \frac{1}{2}$ minutes); $.75 \mathrm{mg}$ for one-month-old s-123 (induction time, 5 minutes); and, $1 \mathrm{mg}$ for two-month-old s-128 (induction time, 5 minutes). Body weight of S-128 was estimated to be 185 pounds. 
TABLE III

DOSAGE, INDUCTION AND RECOVERY DATA

FOR FREE-LIVING FEMALE ADULT ELK

\begin{tabular}{|c|c|c|c|c|}
\hline $\begin{array}{c}\text { Quantity } \\
\text { (M 99) } \\
\end{array}$ & $\begin{array}{l}\text { Induction } \\
\text { (minutes) } \\
\end{array}$ & $\begin{array}{l}\text { Quantity } \\
\text { (M 50-50) } \\
\end{array}$ & $\begin{array}{l}\text { Recovery } \\
\text { (minutes) } \\
\end{array}$ & Remarks \\
\hline $5 \mathrm{mg}$ & 10 & $10 \mathrm{mg}$ & 4.0 & $\begin{array}{l}\text { M 50-50 given } \\
\text { intramus cularly }\end{array}$ \\
\hline $5 \mathrm{mg}$ & 20 & $10 \mathrm{mg}$ & 1.0 & \\
\hline $5 \mathrm{mg}$ & 30 & $10 \mathrm{mg}$ & 1.0 & \\
\hline $6 \mathrm{mg}$ & 18 & $14 \mathrm{mg}$ & 0.8 & \\
\hline $6 \mathrm{mg}$ & 21 & $12 \mathrm{mg}$ & 0.8 & \\
\hline $6.5 \mathrm{mg}$ & 15 & $12 \mathrm{mg}$ & 0.7 & \\
\hline $6.5 \mathrm{mg}$ & 29 & $12 \mathrm{mg}$ & 0.8 & \\
\hline $7 \mathrm{mg}$ & 15 & $14 \mathrm{mg}$ & 1.1 & \\
\hline $7 \mathrm{mg}$ & 15 & $14 \mathrm{mg}$ & 1.0 & \\
\hline $7 \mathrm{mg}$ & 15 & $14 \mathrm{mg}$ & 1.0 & \\
\hline $7 \mathrm{mg}$ & 16 & $14 \mathrm{mg}$ & 1.0 & \\
\hline $7 \mathrm{mg}$ & 19 & $14 \mathrm{mg}$ & 1.0 & \\
\hline $7 \mathrm{mg}$ & 20 & $14 \mathrm{mg}$ & 0.7 & \\
\hline $7 \mathrm{mg}$ & 20 & $14 \mathrm{mg}$ & 1.0 & \\
\hline $7 \mathrm{mg}$ & 21 & $14 \mathrm{mg}$ & 1.0 & \\
\hline $7 \mathrm{mg}$ & 21 & $14 \mathrm{mg}$ & 1.0 & \\
\hline $7 \mathrm{mg}$ & 34 & $14 \mathrm{mg}$ & 0.8 & \\
\hline $7 \mathrm{mg}$ & 35 & $14 \mathrm{mg}$ & 1.0 & $\begin{array}{l}\text { M } 99 \text { given in } 2 \text { doses } \\
24 \text { minutes apart }\end{array}$ \\
\hline
\end{tabular}

Recommended: $7 \mathrm{mg}$ ( $7 \mathrm{cc}$ ) M 99 with $20 \mathrm{mg}$ ( $1 \mathrm{cc}$ ) Vesprin 
TABLE IV

DOSAGE, INDUCTION AND RECOVERY DATA

FOR FREE-LIVING FEMALE YEARLING ELK

\begin{tabular}{|c|c|c|c|c|}
\hline $\begin{array}{l}\text { Quantity } \\
\text { (M 99) } \\
\end{array}$ & $\begin{array}{l}\text { Induction } \\
\text { (minutes) } \\
\end{array}$ & $\begin{array}{l}\text { Quantity } \\
\text { (M 50-50) } \\
\end{array}$ & $\begin{array}{l}\text { Recovery } \\
\text { (Minutes) } \\
\end{array}$ & Remarks \\
\hline $3 \mathrm{mg}$ & 3 & $6 \mathrm{mg}$ & 1.0 & Near base of tail \\
\hline $3 \mathrm{mg}$ & 10 & $6 \mathrm{mg}$ & 0.5 & $\begin{array}{l}\text { M } 50-50 \text { given in the } \\
\text { jugular vein }\end{array}$ \\
\hline $3 \mathrm{mg}$ & 10 & $6 \mathrm{mg}$ & 11.0 & $\begin{array}{l}\text { M 50-50 in neck } \\
\text { muscle }\end{array}$ \\
\hline $3 \mathrm{mg}$ & 11 & $6 \mathrm{mg}$ & 1.0 & \\
\hline $3 \mathrm{mg}$ & 14 & $6 \mathrm{mg}$ & 0.7 & \\
\hline $3 \mathrm{mg}$ & 15 & $6 \mathrm{mg}$ & 0.7 & \\
\hline $3 \mathrm{mg}$ & 15 & $8 \mathrm{mg}$ & 1.0 & $\begin{array}{l}\text { Some restraint } \\
\text { necessary }\end{array}$ \\
\hline $3 \mathrm{mg}$ & 16 & $6 \mathrm{mg}$ & 1.1 & \\
\hline $3 \mathrm{mg}$ & 17 & $6 \mathrm{mg}$ & 1.0 & Poorly placed dart \\
\hline $4 \mathrm{mg}$ & 16 & $4 \mathrm{mg}$ & 1.0 & $\begin{array}{l}\text { Reduced amount of } \\
\text { M 50-50 }\end{array}$ \\
\hline $4 \mathrm{mg}$ & 28 & $8 \mathrm{mg}$ & 0.8 & $\begin{array}{l}\text { Some restraint neces- } \\
\text { sary }\end{array}$ \\
\hline $5 \mathrm{mg}$ & 13 & $10 \mathrm{mg}$ & 1.0 & \\
\hline $5 \mathrm{mg}$ & 17 & $10 \mathrm{mg}$ & 1.0 & \\
\hline $5 \mathrm{mg}$ & 19 & $10 \mathrm{mg}$ & 0.5 & \\
\hline $7 \mathrm{mg}$ & 6 & $14 \mathrm{mg}$ & 1.0 & \\
\hline $7 \mathrm{mg}$ & 14 & $14 \mathrm{mg}$ & 2.0 & \\
\hline
\end{tabular}

Recommended: $4.5 \mathrm{mg}(4.5 \mathrm{cc})$ M 99 with $20 \mathrm{mg}(1 \mathrm{cc})$ Vesprin 
TABLE V

DOSAGE, INDUCTION AND RECOVERY DATA

FOR FREE-LIVING MALE YEARLING ELK

\begin{tabular}{|c|c|c|c|c|}
\hline $\begin{array}{c}\text { Quantity } \\
\text { (M 99) }\end{array}$ & $\begin{array}{l}\text { Induction } \\
\text { (minutes) } \\
\end{array}$ & $\begin{array}{l}\text { Quantity } \\
\text { (M 50-50) } \\
\end{array}$ & $\begin{array}{l}\text { Recovery } \\
\text { (minutes) }\end{array}$ & Remarks \\
\hline $3 \mathrm{mg}$ & 20 & $6 \mathrm{mg}$ & 0.5 & Quantity of M 99 insufficient \\
\hline $4 \mathrm{mg}$ & 6 & $8 \mathrm{mg}$ & 0.8 & \\
\hline $4 \mathrm{mg}$ & 6 & $8 \mathrm{mg}$ & 1.0 & \\
\hline $4 \mathrm{mg}$ & -- & $8 \mathrm{mg}$ & 1.0 & \\
\hline $4 \mathrm{mg}$ & 9 & $8 \mathrm{mg}$ & 1.0 & \\
\hline $4 \mathrm{mg}$ & 10 & $8 \mathrm{mg}$ & 1.0 & \\
\hline $4 \mathrm{mg}$ & 11 & $8 \mathrm{mg}$ & 1.0 & Some restraint necessary \\
\hline $4 \mathrm{mg}$ & 15 & $8 \mathrm{mg}$ & 1.0 & \\
\hline $4 \mathrm{mg}$ & 15 & $8 \mathrm{mg}$ & 0.8 & Quantity of M 99 insufficient \\
\hline $5 \mathrm{mg}$ & 7 & $10 \mathrm{mg}$ & 1.3 & \\
\hline $5 \mathrm{mg}$ & 9 & $10 \mathrm{mg}$ & 1.0 & \\
\hline $5 \mathrm{mg}$ & 9 & $10 \mathrm{mg}$ & 2.0 & \\
\hline $5 \mathrm{mg}$ & $\ldots$ & $4 \mathrm{mg}$ & 1.3 & $\begin{array}{l}\text { Given a lower dose of } \\
\text { M 50-50 }\end{array}$ \\
\hline $5 \mathrm{mg}$ & 10 & $10 \mathrm{mg}$ & 1.2 & \\
\hline $5 \mathrm{mg}$ & 16 & $8 \mathrm{mg}$ & 1.3 & $\begin{array}{l}\text { Poorly placed in patellar } \\
\text { region }\end{array}$ \\
\hline $5 \mathrm{mg}$ & 39 & $10 \mathrm{mg}$ & 0.6 & Quantity of M 99 insufficient \\
\hline $6 \mathrm{mg}$ & 9 & $10 \mathrm{mg}$ & 1.0 & \\
\hline $8 \mathrm{mg}$ & 10 & $8 \mathrm{mg}$ & 1.5 & $\begin{array}{l}\text { 2nd dose of } 4 \mathrm{mg} \text { given } \\
\text { intravenous } 1 \mathrm{y} \text { by error }\end{array}$ \\
\hline
\end{tabular}

Recommended: $\quad 5 \mathrm{mg}$ (5 cc) M 99 with $20 \mathrm{mg}$ (1 cc) Vesprin 
A substantial difference was found between drug requirements for captive elk as compared with trapped, free-living animals. Usually, the effective dosage for captive elk was about half the mean amount required to immobilize free-living elk. Induction time for captive elk was about one-third that required to Immobilize a free-living animal. The dosage of antagonistic drug, as well, was only half that administered to temporarily trapped $e 1 k$, and recovery time of one to two minutes occurred with the lesser quantity.

Examples that illustrate the lower amounts of M 99 needed to render captive elk amenable to handling (Figure 6) include: $2.75 \mathrm{mg}$ for adult male S-121, with an induction time of eight minutes and estimated body weight of 350 pounds; and, $4 \mathrm{mg}$ for adult female s-124, with an induction time of 13 minutes and estimated body weight of 500 pounds.

It was necessary to decrease further the dosage for a captive animal in poor condition. For example, $2 \mathrm{mg}$ of $M 99$ were adequate to immobi11ze a mature elk cow (Z-11) at the Portland Zoo (Figure 6), for diagnosis and treatment of posterior paresis. Her condition failed to improve, and when she was immobilized again one year later, only $1 \mathrm{mg}$ of M 99 proved to be an adequate amount.

Table VI summarizes the characteristics of the two main immobilizing agents commonly used for elk.

\section{DISCUSSION}

Seal and Erickson (1969) found that free-living animals required larger dosages of drugs for immobilization than animals of the same species in a zoo situation, and that very young animals of many spectes 
COMPARISON OF USE CHARACTERISTICS OF ETORPHINE AND SUCCINYLCHOLINE CHLORIDE

\section{Etorphine *}

1. Slow immobilization time

2. Wide safety margin

3. One concentration available

4. Need 5-7 cc darts

5. Rap1d recovery rate

6. Cost per animal handled: (5 cc) $\$ 11.30$, including Vesprin and Diprenorphine (M 50-50)

7. No mortalities associated with use

8. License from the Bureau of Narcotics and Dangerous Drugs required for purchase, possession and/or use
Succinylcholine chloride**

1. Fast immobilization time

2. Narrow safety margin

3. Several concentrations available

4. Need 1-2 cc darts

5. Slow recovery rate

6. Cost per animal handled: (20 mg) $\$ 0.55$

7. Mortalities associated with use

8. No federal license required

* "M 99" American Cyanamid Company, Princeton, New Jersey, $1 \mathrm{mg} / \mathrm{cc}$

** "Sucostrin", E. R. Squibb and Sons, New York, New York, $20 \mathrm{mg} / \mathrm{cc}$ 
required and tolerated amounts slightly larger on a body weight basis than adults. They also noted that females of many species were more rapidly and completely relaxed at a given dosage than the males, and that anemic animals were more rapidly and completely relaxed than animals without anemia. Observations of elk immobilized during my study lend support to all four of these findings of Seal and Erickson.

The primary advantage of M 99 over succinylcholine chloride is the wide safety margin of $M 99$, which was used to immobilize $75 \mathrm{elk}$, as well as numerous other hoofed animals, during min study with no mortalities. Sucostrin was used on $7 \mathrm{elk}$ and was implicated in 2 mortalitites. The possibility exists that elk, too, are subject to a delayed reaction similar to that described by Fujita (1970). Deaths attributed to poorly placed darts or drug overdose are frequently reported by workers using Sucostrin.

Another major advantage of M99 is that additional doses may be given if the animal fails to respond to the initial injection. Sucostrin tends to be a "one shot" drug. This creates the problem of not being able to give additional doses without endangering the elk. Elk not responding to Sucostrin must often be handled with ropes.

The availability of the companion drug $M$ 50-50 for rapid recovery also favors $M 99$. An average of 1.1 minutes was required for adult cows to recover from the effects of M 99 (after receiving M 50-50); the same age class immobllized with Sucostrin required 23 minutes to recover.

CONCLUSIONS

Sex and age class are both important in determining the amount of 
M 99 to be administered to elk. Animal condition is another important factor in determining the amount of drug needed for immobilization. The need to increase the quantity of M 99 administered to yearling elk between June and July can be ascribed to improved body condition in response to good forage on summer range, and to normal growth as they begin their second year of 1ife.

Because of its slow induction time (at the dosages tested), M 99 does not appear to be satisfactory for field use on freely moving elk. In adult cows, the mean induction time for $M 99$ was 21 minutes; the mean for Sucostrin was 5.3 minutes. Larger darts (5-7 cc vs. 1-2 cc syringes) are required for $M 99$ than for Sucostrin, increasing the cost and decreasing the effective range of Cap-chur equipment. Succinylcholine chloride is available in $20 \mathrm{mg}$ and $50 \mathrm{mg} / \mathrm{cc}$ concentrations while M 99 has a concentration of $1 \mathrm{mg} / \mathrm{cc}$.

Sucostrin appears to be the more satisfactory drug for field use on freely moving elk or when rapid immobilization is desired. For use with trapped elk, when immobilizing animals in close proximity to the public, and when animal safety is especially important, M 99 with M 50-50 appears to be the better drug combination.

The recommended dosage for yearling cows is $4.5 \mathrm{mg} M 99$ in combination with $20 \mathrm{mg}(1 \mathrm{cc})$ Vesprin, for yearling bulls is $5 \mathrm{mg} \mathrm{M} 99$ with 20 $\mathrm{mg}$ ( $1 \mathrm{cc}$ ) Vesprin, and for adult cows is $7 \mathrm{mg} \mathrm{M} 99$ with $20 \mathrm{mg}$ (1 cc) Vesprin. 
CHAPTER III

HEMATOLOGY

Interest in hematology as an aid to diagnosis in the field of veterinary medicine is extending to increasing numbers of species (Dieterich 1970; Schalm 1965). However, the information gained from blood analysis is not useful in diagnostic procedures unless the values obtained can be correlated with known normal values. As Kitchen and Pritchard (1962:111) stated: "Red blood cell counts and white blood cell counts are useful in determining healthy versus abnormal animals when normal ranges have been established for the species." Blood values for well-nourished captive elk accustomed to the presence of man and for free-living elk temporarily penned, are reported here in an attempt to document normal ranges.

Although the American elk is an important species in the western United States, both as a game animal and as an aesthetic addition in parks and wildernesses, its hematology has received only cursory attention. Herin (1968) reported some blood values for elk from Rocky Mountain National Park, Colorado. In his study of the elk of the White River Plateau, Colorado, Boyd (1970) included a partial hemogram which he compared with data from domestic ungulates and man.

\section{METHODS AND MATERIALS}

Blood was drawn by jugular venipuncture using a 36 " blood collection set with siliconed needles (Abbott Laboratories, North Chicago, Illinols 60064). One 5 mí evacuated tube (V̄acutainer, Becton, 
Dickinson \& Co., Columbus, Nebraska) containing $0.04 \mathrm{ml}$ of $30 \%$ EDTA solution and two $10 \mathrm{ml}$ evacuated tubes containing no anticoagulant were filled. A drop of blood from the needle was used to make a smear for Schilling differential counts. Fresh blood smears eliminated the distortion of leukocytes observed when slides were made from EDTA-treated blood. Use of Wright-Giemsa stain (National Biological Stains and Reagents, Allied Chemical, P. 0. Box 1069, Buffalo, New York 14240) gave clear cellular differentiation and facilitated examination for hemoparasitism. One hundred leukocytes were selected by the Battlement method, identified as to type, and counted under oil imersion for differential counts (Schalm 1965).

Although it was possible to increase sample sizes by taking blood from recently shot elk, I limited the hematology aspect of this study to living animals in order to thereby obtain values which could be considered "normal". Kocan (1972) found that hematological measurements from wounded or dying animals were extremely variable.

Hemoglobin concentration (in grams/100 ml of blood) was measured colorimetrically in commercially prepared cyanmethemoglobin reagent prepared for use with the Mode1 360A Serometer (Serosonic Laboratories, Inc., 1644 Locust Ave., Bohemia, L. I. New York 11716). Standard hemoglobin solutions ("Hemotro1") were used with every five or fewer samples. Packed cell volume (PCV) was determined by the microhematocrit method (Schalm 1965) with centrifugation of cap1llary tubes at $12,500 \mathrm{rpm}$ for 4 minutes in an Adams autocrit centrifuge (Clay Adams, Division of Becton, Dickinson \& Company, Parsippany, New Jersey 07054). Total cell counts were determined using a 1:200 dilution (red ce11s) with Hayem 
blood diluting fluid (National Biological Stains and Reagents, Allied Chemical, P. 0. Box 1069, Buffalo, New York 14240) in a red blood cell pipette, and a 1:20 dilution (white cells) with acetic acid solution (Harleco, 60th \& Woodland Ave., Philadelphia, Pa. 19143) in a white cell pipette. Both erythrocytes and Ieukocytes were counted on a Spencer Bright Line hemocytometer (American Optical Company, Instrument Division, Buffalo 15, New York). The three standard erythrocytic indices -- MCV (mean corpuscular volume, 1.e., volume/ce11), MCH (mean corpuscular hemoglobin, 1.e., weight of hemoglobin/ce11), and MCHC (mean corpuscular hemoglobin concentration, i.e., weight of hemoglobin/cell volume) -- were calculated.

whenever elapsed time from the drawing of blood until analysis or other problems due to field conditions jeopardized accuracy, the findings were omitted from this study. Thus, measurements from zoo elk are more extensive than those from free-living animals.

RESULTS

Hematological data obtained for $60 \mathrm{elk}$ are grouped and summarized in Table VII. The frequency distribution of values for hemoglobin, mean corpuscular hemoglobin, and mean corpuscular volume are shown in Figures 6A, 6B, and $6 \mathrm{C}$.

Respiration rate, heart rate, and rectal temperature for elk subjected to two different techniques of handling are given in Table VIII. These three readings reflect response to activity and excitement, and are significant because of the close relationship that exists between excitement and blood values. Readings for captive calves are grouped 
WHOLE BLOOD VALUES FOR FREE-LIVING AND CAPTIVE ELK WITH STATISTICAL DESCRIPTION

$\begin{gathered}\text { Value } \\ \text { (units) }\end{gathered}$
Hemoglobin (grams/100 ml)
Packed Cell Volume (\%)
Erythrocytes (10\%/mm 3$)$
MCH (micromicrograms)
MCHC (\%)
MCV (cubic microns)
Leukocytes/mm 3
DIFFERENTIAL
Neutrophils (\%)
Band cells (\%)
Lymphocytes (\%)
Monocytes (\%)
Eosinophils (\%)
Basophils (\%)

\begin{tabular}{rrr} 
Mean & \multicolumn{1}{l}{ SD } & \multicolumn{1}{l}{ SE } \\
17.1 & 2.1 & 0.3 \\
44.9 & 5.5 & 0.7 \\
9.9 & 1.7 & 0.4 \\
16.2 & 2.5 & 0.5 \\
38.3 & 3.9 & 0.5 \\
44.3 & 6.6 & 1.5 \\
5346. & 1450. & 274. \\
48.0 & 16.0 & 2.6 \\
. .1 &. .4 & .06 \\
35.2 & 14.9 & 2.5 \\
7.4 & 4.5 & .7 \\
8.3 & 6.1 & 1.0 \\
0.7 & 1.0 & 0.2
\end{tabular}

Low

10.1

33.0

6.2

10.1

25.9

34.8

2550 .

14.0
0.0
14.0
2.0
1.0
0.0

Number of Elk Tested 53

60

20

20

53

20

28

7700 .

$78.0 \quad 37$

$2.0 \quad 37$

$65.0 \quad 37$

$22.0 \quad 37$

$27.0 \quad 37$

$\begin{array}{ll}4.0 & 37\end{array}$ 

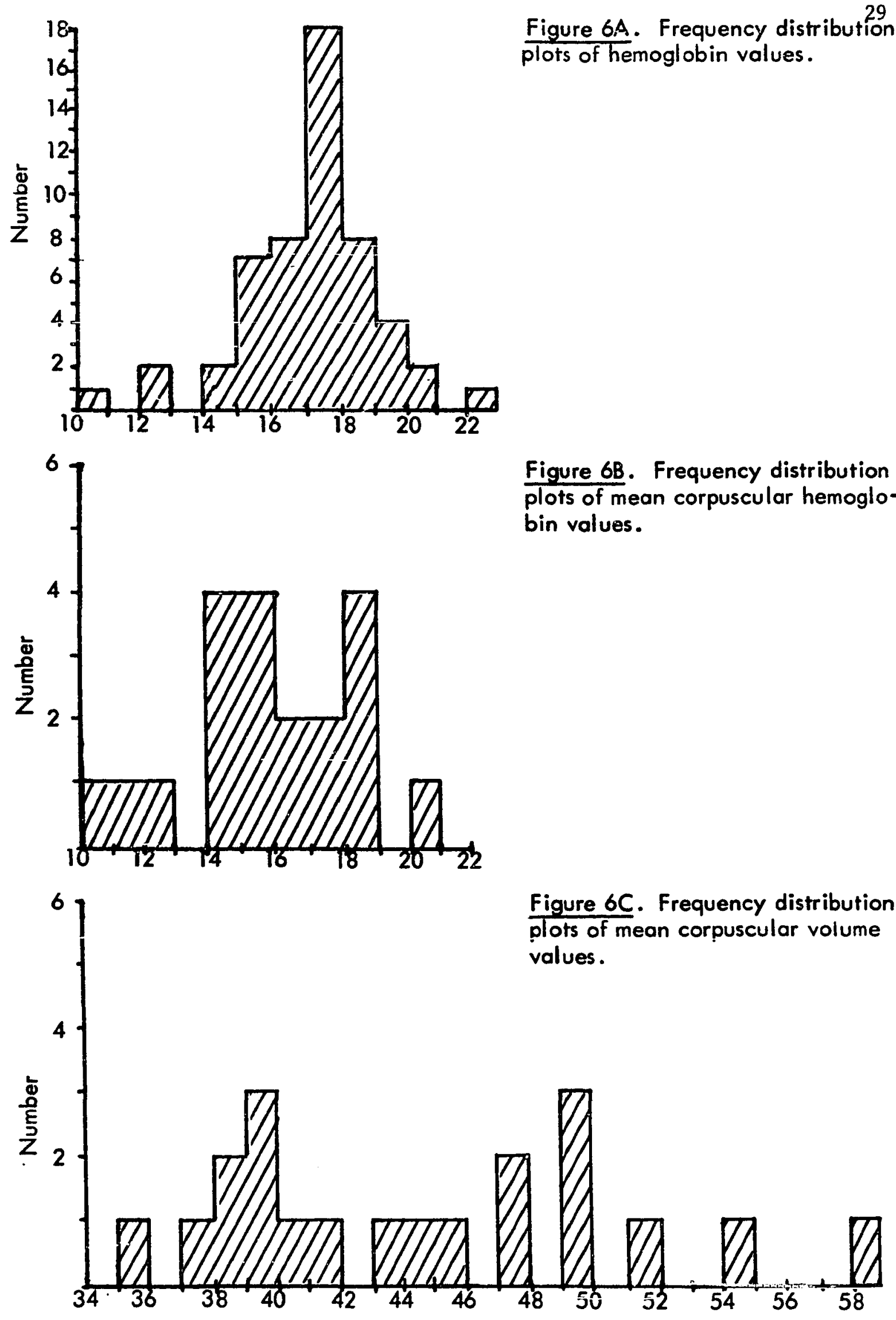

Figure 6A. Frequency distribution plots of hemoglobin values.

Figure 6B. Frequency distribution plots of mean corpuscular hemoglobin values. 
SOME PHYSIOLOCIAL RESPONSES OF CAPTIVE ELK (DRUGGED) AND FREE-LIVING ELK (SQUEEZE CHUTE)

\section{Animal}

CAPTIVE

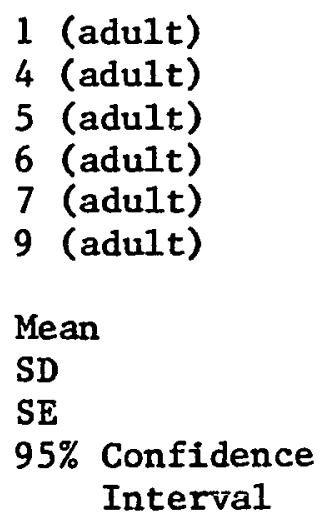

2 (calf)

3 (calf)

8 (calf)

Mean

SD

SE

95\% Confidence

Interval

FREE-LIVING*

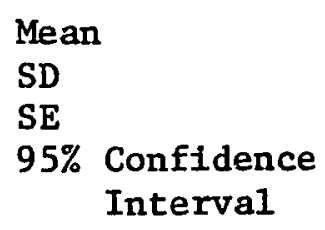

Respiration

Rate/min

13

19

20

11

19

18

\section{7 \\ 3.7 \\ 1.5}

$13.8-19.5$

23

24

32

26.3

4.9

2.8

$14.8-37.8$

$41.0-69.7$

$45.9-76.7$

52

62

52

55.3

5.8

3.3

1.3

6.0

64

49

80

2

Rate/min

0

4

101.5

102.8

101.8

101.8

102.9

102.1
102.2
0.6
0.2

$101.5-102.8$

102.3

103.0

103.4

102.9

0.6

0.3

$101.5-104.3$

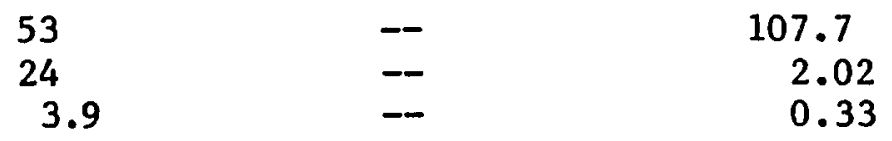

$45.1-60.9$

-- $\quad 107.0-108.4$

* From Herin (1968) for elk of mixed ages and sexes 
separately. A mean temperature of $102.1^{\circ} \mathrm{F}\left(38.9^{\circ} \mathrm{C}\right)$ with a range of $101.5^{\circ} \mathrm{F}$ to $102.9^{\circ} \mathrm{F}$ was obtained, which may be near the normal body temperature for adult elk. The frequency distribution of respiration rate, heart rate and temperature values for drugged elk are shown in Figure 6D.

For comparative purposes, hematological values obtained by Boyd (1970) and Herin (1968) from their studies of elk in Colorado are summarized with my findings in Table IX. Hemoglobin, packed cell volume, and mean corpuscular hemoglobin concentration data are summarized in Table X for two age groups of captive $e 1 k$, and in Table XI for two age groups of free-living elk. The frequency distribution of hematological values for two age groups of captive elk are shown in Figure 6E, and for two age groups of free-living elk in Figure 6F.

Antsocytosis (variability in RBC size) was commonly observed and varied from slight to moderate to marked, in different individuals. This phenomenon is normal in healthy cattle (Schalm 1965), and perhaps In $e 1 k$, as well.

Three cow elk with low hemoglobin exhibited rouleaux formation, in which erythrocytes are arranged in a roll or column similar in appearance to a roll or stack of coins. Rouleaux are absent in healthy cattle but may become prominent in the very sick (Schalm 1965:167). Rouleaux are, however, commonly seen in blood films from healthy horses.

\section{DISCUSSION}

Considerable variation in hemoglobin values has been observed between mammalian spectes; the observed variation cannot be satisfactorily 

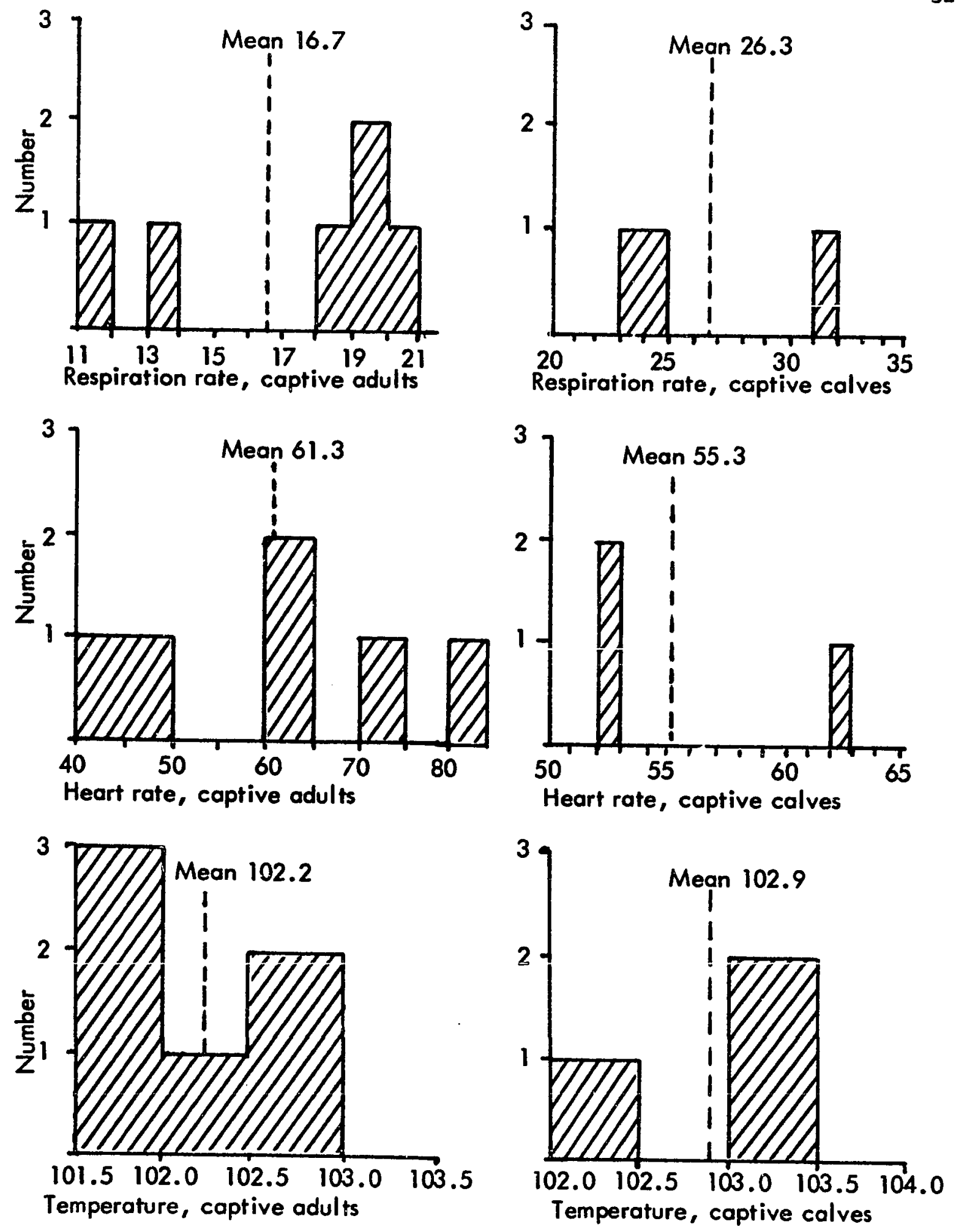

Figure 6D. Frequency distribution plots of physiologica! responses of diugged elk. 
TABLE IX

HEMATOLOGICAL VALUES FOR ELK FROM THREE AREAS OF THE WESTERN UNITED STATES

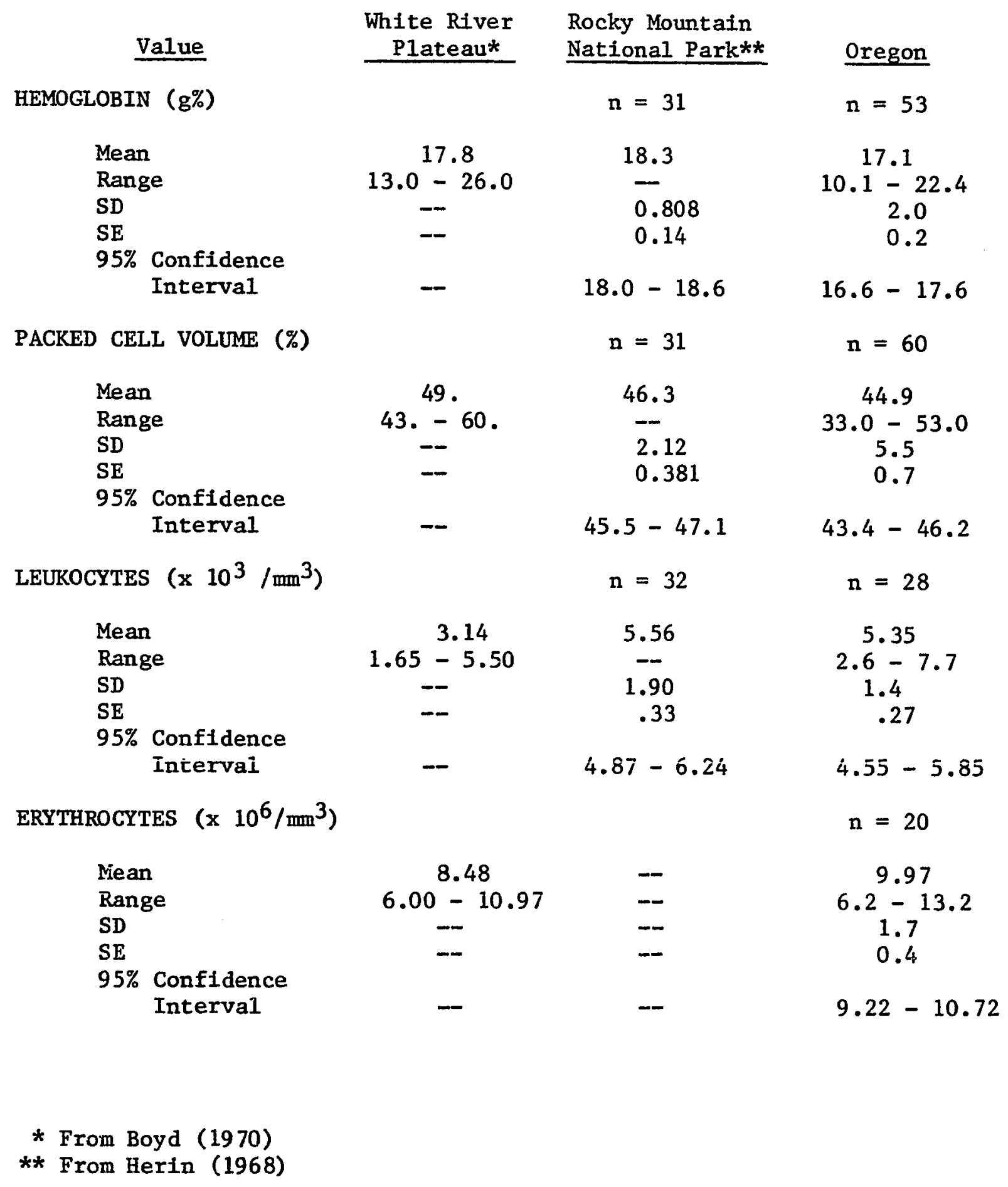


TABLE X

\section{SUMMARY OF HEMATOLOGICAL VALUES FOR TWO AGE GROUPS OF CAPTIVE ELK}

Young*

$\underline{01 d * *}$

\section{HEMOGLOBIN ( $\mathrm{g} / 100 \mathrm{ml})$}

$$
\begin{aligned}
\text { Mean } & =17.5 \\
\text { Variance } & =2.8 \\
\mathrm{SD} & =1.6 \\
\mathrm{SE} & =0.4 \\
\text { Range } & =14.4-20.3 \\
\mathbf{n} & =14
\end{aligned}
$$

$$
\begin{aligned}
\text { Mean } & =16.6 \\
\text { Vartance } & =5.3 \\
\mathrm{SD} & =2.3 \\
\mathrm{SE} & =0.7 \\
\text { Range } & =12.2-20.7 \\
\mathrm{n} & =11
\end{aligned}
$$

\section{PACKED CELL VOLUME (\%)}

$$
\begin{aligned}
\text { Mean } & =46.4 \\
\text { Variance } & =17.9 \\
\mathrm{SD} & =4.2 \\
\mathrm{SE} & =1.1 \\
\text { Range } & =36.5-53.0 \\
\mathbf{n} & =14
\end{aligned}
$$

$$
\begin{aligned}
\text { Mean } & =43.5 \\
\text { Variance } & =24.9 \\
\mathrm{SD} & =4.9 \\
\mathrm{SE} & =1.4 \\
\text { Range } & =33.0-51.0 \\
\mathbf{n} & =12
\end{aligned}
$$

MEAN CORPUSCULAR HEMOGLOBIN CONCENTRATION (\%)

$$
\begin{aligned}
\text { Mean } & =37.8 \\
\text { Variance } & =2.8 \\
\mathrm{SD} & =1.7 \\
\mathrm{SE} & =0.4 \\
\text { Range } & =34.9-41.4 \\
\mathrm{n} & =14
\end{aligned}
$$

$$
\begin{aligned}
\text { Mean } & =37.7 \\
\text { Vartance } & =3.9 \\
\mathrm{SD} & =1.9 \\
\mathrm{SE} & =0.6 \\
\text { Range } & =34.9-40.9 \\
\mathrm{n} & =11
\end{aligned}
$$

\footnotetext{
* Two years of age or less
}

** Over two years of age 

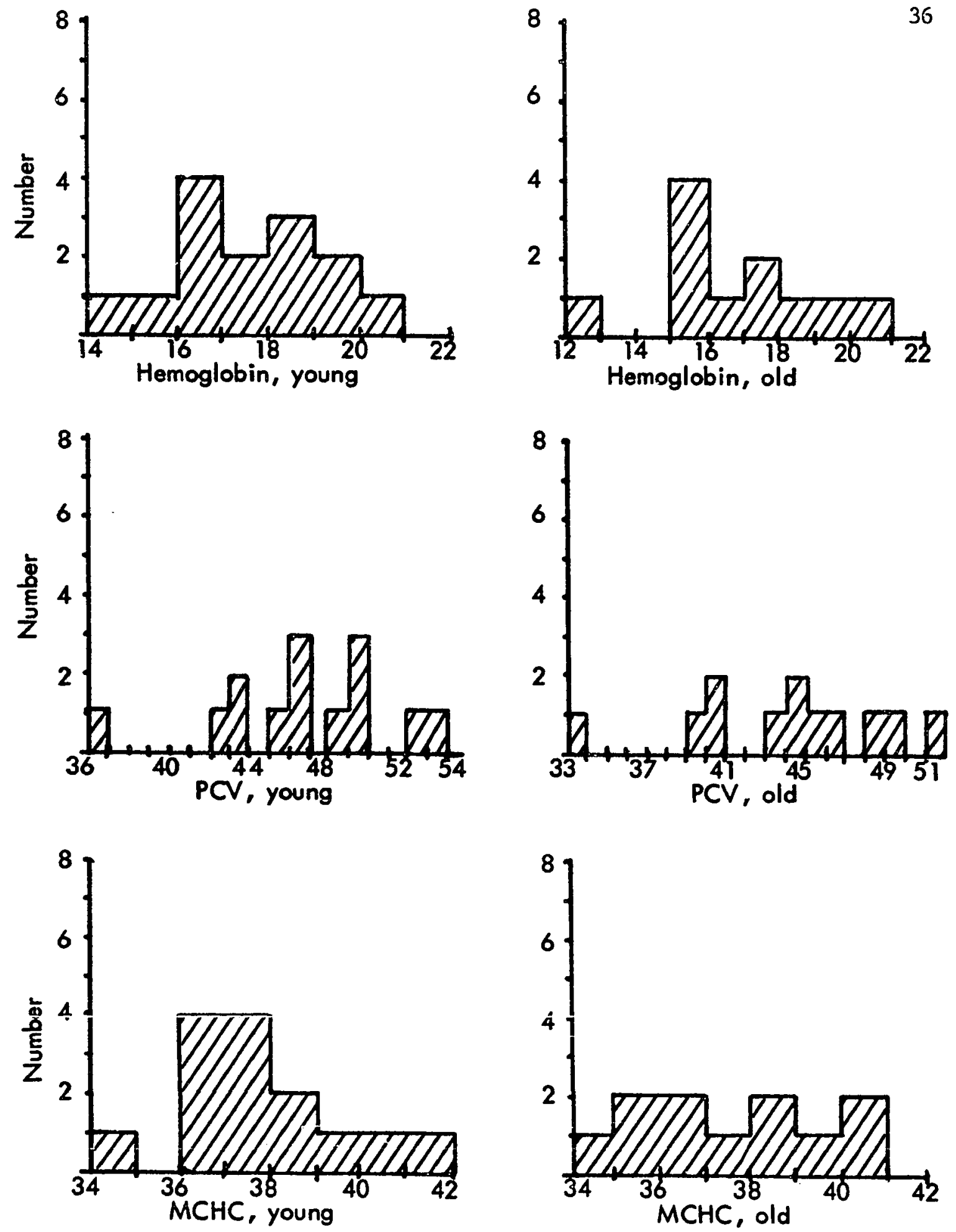

Figure 6E. Frequency distribution plots of hematological values for two age groups of captive elk. 

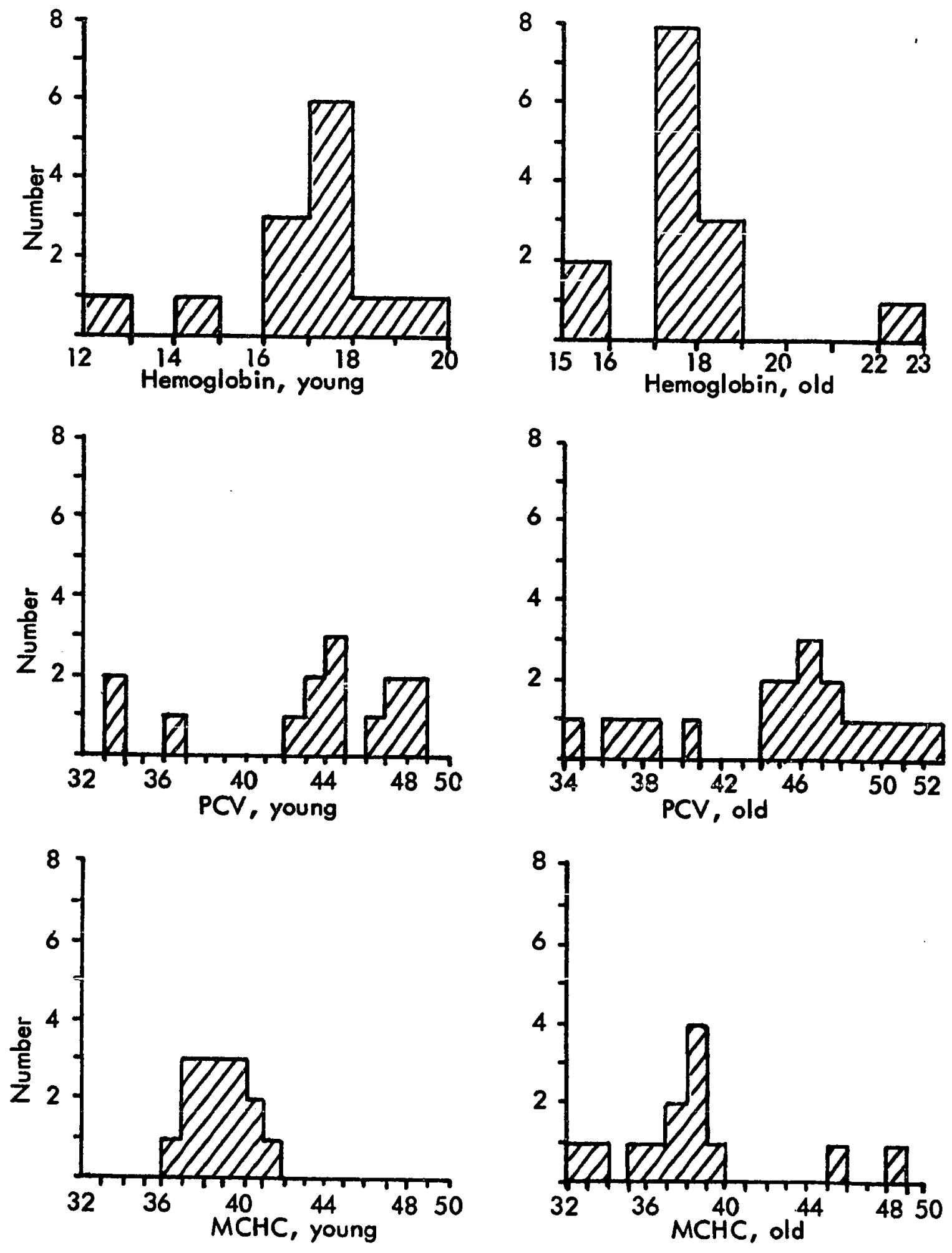

Figure 6F. Frequency distribution plots of hemotological values for two age groups of free-living elk. 
explained in correlation with body size, activity, or metabolic patterns (Youatt et al. 1961; Wintrobe 1933). Active animals, 1ike elk and other cervids, may have greater hemoglobin needs than more lethargic species, like cattle, sheep, goats or cats (Schalm 1965:191). An example of this is seen in findings. The mean hemoglobin $(17.1 \pm 2.0 \mathrm{~g} / 100 \mathrm{ml})$ for elk is higher than that of domestic ruminants but similar to values reported for free-living species such as bighorn sheep (Woolf and Kradel 1970) and mule deer (Anderson et al. 1970). Kitchen and Pritchard (1962) compared a free-living cervid and a domestic ungulate, using calculations based on the ability of each gram of hemoglobin to carry $1.34 \mathrm{ml}$ of bound oxygen and each $200 \mathrm{ml}$ of plasma to carry $.3 \mathrm{ml}$ of dissolved oxygen. They found that a 96 pound sheep with a normal $13 \mathrm{~g}$ of hemoglobin per $100 \mathrm{ml}$ of blood and the same volume of blood as a deer of equal size would have an oxygen carrying capacity of $648 \mathrm{ml}$ of oxygen, whereas a 96 pound white-tailed deer with its normal $20 \mathrm{~g}$ of hemoglobin/ $100 \mathrm{ml}$ of blood and a packed cell volume of $60 \%$ would have a carrying capacity of $1,001 \mathrm{ml}$ of oxygen. Horses of Arabian ancestry, commonly called "hot-blooded", have a mean hemoglobin level of $15.0 \mathrm{~g} / 100 \mathrm{ml}$, whereas "cold-blooded" horses that lack the Arabian ancestry have a mean hemoglobin value of $11.5 \mathrm{~g} / 100 \mathrm{ml}$ (Schalm 1965:251). Additional indepth Investigations involving a number of species need to be undertaken to determine the basis for observed differences of this kind.

Packed cell volume, the volume percent of formed elements (primarily erythrocytes) in the blood, is a reliable figure as long as the speed and duration of centrifugation are standardized. Anemia exists when the PCV falls below the minimum normal range established for the 
species. Hemoconcentration may be present when the PCV exceeds the maximum of the normal range. An anemic animal in a state of hemoconcentration may have a PCV in the normal range (Schalm 1965).

The three erythrocytic indices ( $\mathrm{MCV}, \mathrm{MCH}$, and $\mathrm{MCHC}$ ) are particularly useful in diagnosing and classifying the various types of anemia. For Instance, in response to acute blood 10ss, such as occurs with the hemolytic anemia of anaplasmosis, a disease to which elk are subject, the MCH may show a marked increase to above normal levels (Schalm 1965: 397). It was commonly believed that the weight of hemoglobin that could be held by a red cell rarely exceeded 35 percent, hence a MCHC value greater than 35 percent was seldom valid (Schalm 1965:113). Since the introduction of the microhematocrit method, which produces a PCV with less trapped plasma, the MCHC may exceed 35 percent, as I generally found true for elk. Hypochromic anemia is characterized by the MCHC falling below 30 percent, which I found was the case for an adult eik cow at the Woodland Park Zoo in Seattle with a MCHC of 25.9 percent. When the method for obtaining the packed cell volume value fails to minimize the trapped plasma; as occurred with the older tintrobe hematocrit technique, a lower MCHC index is obtained in the calculation.

Higher values for the packed cell volume of the males of many species of vertebrate have been reported (Davidsohn and Wells 1962; Kaplan 1954), but Seal and Erickson (1969) found higher PCV among females in white-talled deer. My data show a mean of $44.8 \%$ for 19 males and $44.9 \%$ for 41 females, and support the vlew that cervids lack sexual differences in this parameter (Rosen and Bischoff 1952; Anderson et al. 1970). My PCV data for elk $(44.9 \pm 0.7 \%)$ and the $44.8 \pm 0.5 \%$ for 
California mule deer (Rosen and Bischoff 1952) are similar. McEwan and Whitehead (1969) found sex-related seasonal changes in the PCV of adult caribou including a $21 \%$ increase at the beginning of lactation, and a $20 \%$ increase at the onset of rut. Additional saming at specific times of the year would be necessary to adequately assess the influence of reproductive periodicity on elk hematology.

Currently, procedures for collecting and processing cervid blood vary greatly. Some studies report hematologlcal values from deer that have been shot (Browman and Sears 1955; Seal and Erickson 1969; Anderson et al. 1970). Hematological data obtained under such circumstances could reflect more drastic changes than occur with immobilization alone.

Use of the Abbott blood collection set reduced the hemolysis frequently encountered when blood was drawn by needle and syringe, and allowed the filling of different containers without the need to re-enter the animal's vein repeatedly.

The effect of capture, handling, drugs, stress and excitement on variability of blood values of white-tailed deer was evaluated by Seal et al. (1972b). Franzmann and Thorne (1970), using the same Immobilizing drug I did, described reduced excitement and the significance of this factor in obtaining valid base-line data on the physiology of bighorn sheep.

Under the influence of strenuous muscular activity or fright, the spleens of many mammals will contract and force erythrocytes into circulation, causing marked increase in $R B C, P C V$, and hemoglobin values (Dukes 1947; Schalm 1965). Presumably this mechanism functions similarly in elk. Three measurements indicating physiological change due to 
many factors lncluding handling and restraint are given in Table VIII. Respiration rate, heart rate and body temperature are frequently used as indicators of an animal's physiological state. Conditions at the time blood samples are obtained may be highly variable, making it important to provide an Indication of the animal's resposse to excitement, restraint, handling, and drugging. It is, therefore, relevant to compare wy finaiings from elk which were drugged to minimize excitement and activity with the values of Herin (1968) in which elk were not drugged. The elk from which Herin obtained data were forced into a narrow rumway that ended in a squeeze-type cattle chute, and restrained by lateral compression of the chute sides. For the nine Woodland Park zoo elk (Figure 6), conditions favored accurate readings of respiration rate, heart rate and body temperature.

Animal response to fright was markedly reflected in the PCV values reported for arctic mammals by Dieterich (1970) who discussed the impact of this factor upon data obtained from wild animals. Excitability in bighorn sheep and its relationship to blood values were analyzed by Franzmann (1972). Zoo elk appeared to be less frightened than the freeliving elk at the times blood was drawn for this study. A comparison of the hemoglobin, packed cell volume, and mean corpuscular hemoglobin concentration values for the older age groups of captive (Table X) and freeliving (Table XI) elk show higher values for the latter category, as could be expected in response to fright. The expected trend, however, toward higher hematological values among free-living elk was not evident among the younger age groups.

The number of red ceilis per $\mathrm{mm}^{3}$ shows great phylogenetic variation 
among vertebrates, with counts among ungulates being especially high (Wintrobe 1933). The $R B C$ value $\left(9.9 \pm 1.7 \times 10^{6} \mathrm{cells} / \mathrm{mm}^{3}\right)$ I found for elk is substantially higher than found in domestic species, and more closely approximates the data from other wild ruminants (Seal and Erickson 1969; Woolf and Kradel 1970). Because of the close inverse relationship that exists between $\mathrm{RBC}$ number and their size, elk erythrocytes were measured. Diameters varied from 4.5 to 7.0 micra, with 5.0 to 6.0 micra found to be the usual range. This is similar to the RBC size range reported for cattle (Schalm 1965).

The significance of rouleaux formation in elk is not known. Because the presence of rouleaux aids PCV accuracy, it is more difficult to get accurate PCV values for sheep, goats and cattle in which rouleaux do not normally occur.

The mean of leukocytes per $\mathrm{m}^{3}$ I obtained $\left(5,346 \pm 1,450 / \mathrm{mm}^{3}\right)$ is lower on the average than the $5,559 \pm 1,902$ reported by Herin (1968). A higher mean total leukocyte count occurs in calves which are struggling when bled, because of the flushing of leukocytes into clrculation from capillary beds where they remain during relative inactivity (Schalm 1965: 221).

The Schilling differential, or percentage distribution of the different types of leukocytes, probably yields more helpful information for assessing animal condition than any other data obtained from the examination of blood, once the average distribution in the blood of healthy individuals is established (Davidsohn and Wells 1962). Herin (1968) reported a substantially higher percentage of neutrophils (61 \pm $16 \%)$ than I foud $(48.0 \pm 16.0 \%)$. His higher values could be due to 
animal stress, during which adrenal cortical secretion depresses the number of circulating eosinophils and lymphocytes, leading to elevation of neutrophils (Schalm 1965:440). Band cells, or tmmature neutrophils, are regarded as abnormal in number when they exceed $2 \%$ of the WBC in the blood (Schalm 1965:139) of domestic animals. This "shift to the left", the occurrence of young forms of the granulocytic series in peripheral blood in excess of that normally encountered for the species, was evident in one captive elk cow suffering from posterior paresis which was euthanized. Band cells contributed $32 \%$ of the total WBC level, and 1ymphocytes declined to $2 \%$. The outliers resulting from this pathology were deleted from the differential data in Table VII.

Kitts et al. (1956) reported a peak hemoglobin level in yearling Columbian black-tailed deer, and a decrease to lower levels thereafter, which they suggested may indicate a change in the hemopoietic system. The most marked changes in PCV and hemoglobin in dairy cattle occurred during the first two years of life, after which the hematological parameters became relatively stable (Wingfield and Tumbleson 1973). No evidence of age-related differences in elk hematological values was found, as data provided in Tables X and XI indicate. Studies which include a larger number of young animals than were possible in my work would be valuable to clarify this aspect of developmental physiology in elk.

Reduced red cell count and hemoglobin levels were associated with near-starvation conditions among California mule deer (Rosen and Bischoff 1952), but Kitts et al. (1956) found no difference in hemoglobin levels of Columbian black-tailed deer on high and low caloric intake above 
maintenance level. It can be inferred, from the similarity of blood values shown in Tables $X$ and $X I$, that the free-living elk in this study were obtaining adequate forage.

CONCLUSIONS

The data obtained in this study are representative of apparently healthy elk treated as described. Admittedly, the conditions under which I obtained the blood samples are imperfect, and a number of stressors Involved may have affected my results.

It seems evident that wild ruminant specles such as elk, whether captive or free-living, exhibit characteristic hematological values that differ markedly from those of domestic species. It is hoped that as investigations continue, techniques for blood collection will be standardized, as w111 laboratory procedures and methods of constraint, if necessary, to reduce animal stress and thereby reduce these sources of variability. It is possible that remote sensing methods or automatic blood collection equipment fastened in place to function after release of elk will give more "normal" values.

Until such time as more sophisticated techniques are devised and employed, I belleve the values presented here will serve as a contribtuion to the understanding of elk physlology as well as a standard for intraspecific and interspecific comparison for investigators and practitioners working in the field of animal science. 
CHAPTER IV

SICKLING IN ELK

The sickling of erythrocytes in members of the family Cervidae has been shown to resemble closely the tactoid conformation assumed by red cells in human anemia. For this reas on it has received the special attention of scientists.

Gulliver (1840) was probably the first investigator to examine the blood of deer. He was concerned with the morphology of the red cells and was the first to discover the sickle cell phenomenon in deer. He gave an accurate description of the external appearance of these cells, which he found in three different species of tropical cervids, Cervus mexicanus, Cervus reevesii and Cervus porcinus. Gulliver also mentioned sickled cells in a "Persian deer". It should be remembered his observations on sickle cells were made seventy years prior to the description of this form of anemia in man by Herrick (1910).

O'Roke (1936) studied sickle cells in deer and correlated the presence of these cells with an outward physical manifestation of disease, thus giving sickle cells a pathological significance. In contrast, Whitlock (1939) in his studies on the blood of white-tailed deer in Michlgan during a die-off, attributed no pathological significance to sickling. Dougherty (1939) described the sickle cells in Columbian black-tailed deer but attached no clinical significance to the cells. Undritz et al. (1960) induced sickling in the red cells of Pere David deer (Elaphuras davidianus) by saturating their blood with nitrogen, oxygen, or carbon monoxide, thereby producing "respliatory alkalosis", 
but were unable to do so with carbon dioxide. Treatment with the reducing agents $\mathrm{NaHSO}_{3}$ and $\mathrm{Na}_{2} \mathrm{~S}_{2} \mathrm{O}_{5}$, caused sickled cells to return to normal. They found that deer hemoglobin is oxidized by $\mathrm{K}_{3} \mathrm{Fe}(\mathrm{CN})_{6}$ about twice as fast as is human hemoglobin. Undritz et al. (1960) were unable to produce sickling In vitro with the blood of Rangifer tarandus (reindeer), Alces alces (moose), or Cervus canadensis (elk).

Kitchen et al. (1964), working with a captive herd of twenty whitetailed deer in Florida, came to several conclusions concerning sickling. These were: (1) no relationship could be found between sickling and disease in deer; (2) not all deer bloods obtained would sickle when appropriately treated; (3) optimum sickling occurs at a blood pH of 7.3 or greater; (4) multiple hemoglobins may be present in deer blood; and, (5) sickling is due to the formation of hemoglobin tactoids. Sickling has been demonstrated in the barking deer (Muntiacus munt1jak) of Borneo by Dunn (1964) who found the morphology quite common in the Cervidae and agreed with other researchers that it is not of clinical sigüificance. Unlike sickle cell anemia in human belngs, in which red cells containing abnormal s-hemoglobin can be induced to sickle by deoxygenation, red cells in white-tailed deer were found by Kitchen et al. (1964) to assume the characteristic S-shape when subjected to high oxygen tension and an elevated $\mathrm{pH}$.

Noyes et al. (1966) examined the relationship between red cell Iife span and sickling in white-tailed deer and found no deleterious effect on erythrocyte survival due to the ability of cells to sickle. Kitchen et al. (1967) completed work which confirmed their earlier reported findings, including the significant association between 
seven adult hemoglobins with different electrophoretic mobilities and the combination of hemoglobin types which gave rise to sickling of erythrocytes in white-tailed deer. Non-sickling was dependent upon the presence of a speciflc hemoglobin and, as concluded earlier, sickling was a function of $\mathrm{pH}$ and oxygenation.

METHODS AND MATERIALS

In January, 1971, numerous free-ranging wild elk were baited into corral-type traps in southwestern Oregon (FIgure 2). The captured animals included an eight-year-old female (M-8) and an elghteen-month-old female $(M-9)$. Age was determined by the eruption and dentition-wear method of Quimby and Gaab (1957). Both animals were immobilized with succinylcholine chloride ("Sucostrin", $20 \mathrm{mg} / \mathrm{ml}$ from E. R. Squibb \& Sons, New York). Animal M-8 recelved 0.6 cubic centimeters containing 12 milligrams, and M-9 received 0.5 cubic centimeters containing 10 milligrams. Blood was drawn from the external jugular vein for clinical analysis. Smears were made in the usual manner and stained with WrightGiemsa stain. Part of the blood was transferred to a $5 \mathrm{ml}$ container with anticoagulant and capillary tubes prepared for determination of packed cell volume (PCV) as described in Chapter III.

RESULTS

Figure 7 shows a representative field from a blood smear of $M-8$, the older of the two female elk with the sickling condition, and of $M-9$, the younger female. No special treatment was given to induce formation of the sfokleu cells. PCV values were 35.5 percent for $M-8$ and 33.5 


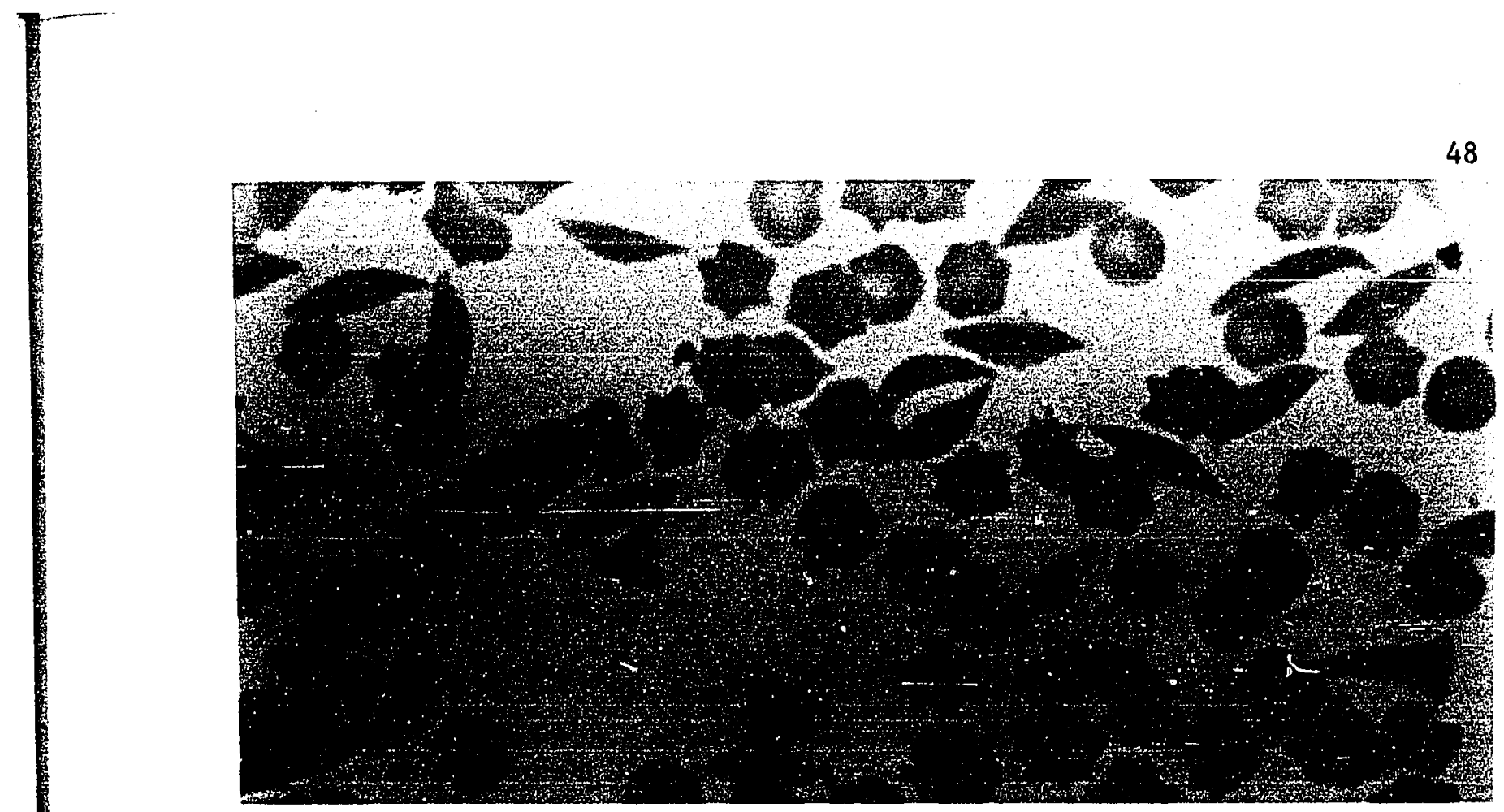

Older cow, M-8

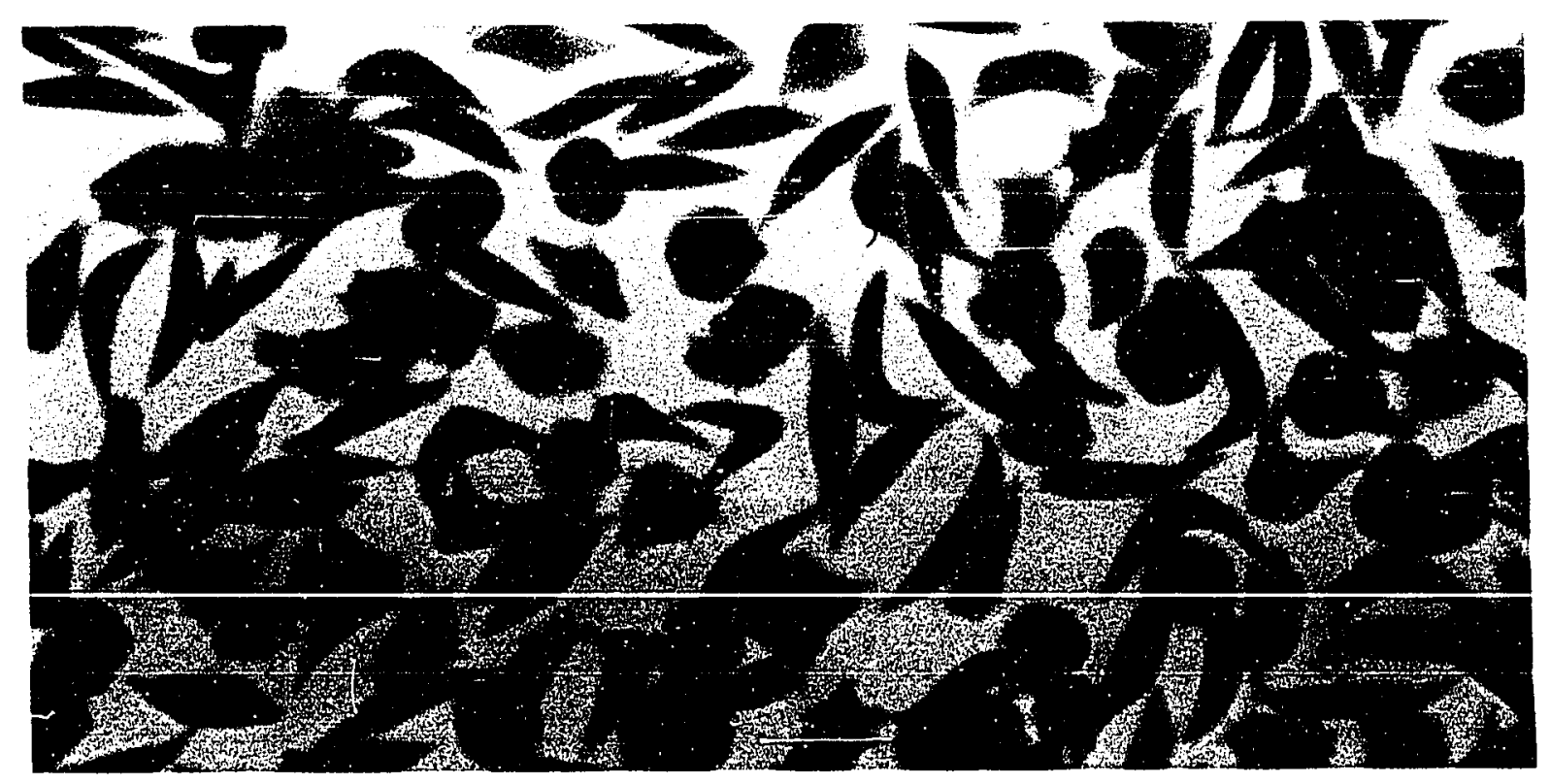

Younger female, M-9

Figure 7. Photomicrographs of blood from two elk showing sickled cells. 
percent for $\mathrm{M}-9$. These two values are in the low range of the PCV data I have compiled for $60 \mathrm{elk}$ from several locallties in Oregon and Washington, which range from 33.0 to 53.0 percent with a mean of 44.9 percent (Table VII). This may be compared to the mean value of 46.3 and STD of 2.12 percent (Table IX) published for this species by Herin (1968).

DISCUSSION

Based on the reproductive and behavioral characteristics of this matriarchal species as described by Graf (1943), it is expected that at this time of year a previous year's calf would be feeding and traveling in the company of its mother. The 18-month-old calf, M-9, had been observed moving together with the 8-year-old cow, M-8, prior to their being trapped together. I suggest, therefore, that the observed sickling has a hereditary basis.

CONCLUSION

Whereas Undritz et al. (1960) were unable to produce sickling in vitro of the erythrocytes of the elk with which they worked, Weber and Giacomett1 (1972) found in vivo sickling of red cells in the blood of Roosevelt elk. This finding of sickle cells in elk increases the list of species available as potential models for the study of sickle cell anemia in man (Cornelius 1969). 
CHAPTER V

SERUM PROTEINS

In the management of free-1iving and captive wild animals, there are many physiological parameters of immediate or potential use in evaluating animal health and well-being, but for most of these, 11ttle information is available regarding range of values that can be considered normal. This is true for the serum proteins. One goal of the present investigations is the definition of ranges for concentrations of various blood and serum components in apparently healthy elk. The hematological parameters have been discussed in Chapter III. The serum proteins will be described in this chapter, and additional serum components will be considered in the chapter that follows.

Serum proteins can be generally grouped into albumin and four globulins - alpha 1 , alpha 2 , beta and gamma. Serum protelns of healthy animals are expected to average $52-60 \%$ albumin, 16-21\% alpha globulin, 11-15\% beta globulin and 12-16\% gamna globulin (Kitchen and Pritchard 1962), but the quantitative variation of proteln fraction distribution among various species is considerable (Schalm 1965). Each fraction is identifiable from its relative mobility under standard experimental conditions.

The primary physlological function of albumin in serum is osmotic regulation. Alpha and beta globulins carry heavy metals, fat soluble vitamins, and phospholipids, and also serve in osmotic regulation. Serum beta globulin includes the transferrins which bind and transport 1ron. The game globulin fraction includes protelne whtch perform the 
a11-important antibody function (Kitchen and Pritchard 1962).

The fractions obtained by electrophoretic separation contain subfractions which can be further differentiated by other techniques. This is especially true of the gamme globulins which contain a series of serologically distinct antibodies. On the other hand, the five isozymes of lactic dehydrogenase may be distributed among the different electrophoretic fractlons (Cohen et al. 1967). A foreign protein resulting from parasttism or other disease states, moving with the same mobility as a normal serum constituent, will be undetected except as it increases the stained band in the region of the normal component. Serum protein determinations have been used extensively to determine the health state of animals and humans.

Herin (1968), while reporting the results of his study, commented on the lack of previously reported data on elk blood proteins. It is possible that Herin did not have access to a translation of the work of Grobov (1961) which includes some values for serum proteins of elk and cattle infected with anaplasmosis. Job completion reports containing data on the serum proteins of $e 1 k$, such as those of the Wyoming Game and Fish Commission which include the findings of Post (1953; 1957), are not generally known or readily available.

The paucity of data for elk makes it necessary to look to research on other species for aid in interpretating the serum protein values obtained in my study.

Serum protein values might be useful in determining the nutritional state of elk, but Albanese et al. (1958) found that total serum protein level is not a dependable criterion of nutritional state in humans. An 
inverse relationship between concentrations of albumin and alpha globulins was found by Chow (1947), but he found no relationship between total protein and albimin values in human patients.

Because it was sometimes necessary for me to freeze serum for my study, the work of Kuttler and Marble (1954) in which they found Insignificant changes due to freezing and storage of sheep serum is important. Because susbstantial differences were found in serum protein concentrations between young and old elk, age-related studies are of interest. Polson (1943) found a steady increase in the total serum protein of horses from birth to two and a half years of age. Reporting a highly significant positive correlation between age and serum protein levels in an I1linols dairy herd, Larson and Touchberry (1.959) attributed the change to an increase in the fractions associated with antibody level. Riegle and Nellor (1966), noted increased plasma protein with age in goats, cows, bulls, rats and sheep and discussed this patterm In relation to adrenocortical function. Tumbleson et al. (1972) found an increase in serum protein concentrations as a function of age in female dairy cattle. Bandy et al. (1957) examined the effect of age and plane of nutrition on the distribution of plasma proteins in Columbian black-tailed deer.

Cowan and Johnston (1962) reported that does of black-talled deer had lower albumin levels than did bucks. Youatt et al. (1965) studied white-tailed deer and gave values for serum proteins in lactating does and their fawns. Tumbleson et a1. (1968) analyzed sera from 46 whitetalled deer to define normal concentrations of total protein, albumin, alpha globulin, beta globulin, gamma globulin and iron. 
Van Tets and Cowan (1966) found serum protein differences between pen-reared and wild-taken deer of the genus Odocoileus. McDougall and Lowe (1968) found differences in quantity and mobllity of serum proteins between red, sika and fallow deer. Anderson et al. (1972) reported on variation in total serum protein associated with sex, age, season, and year in a population of Rocky Mountain mule deer, and observed that Iittle has been published on plasma or serum proteins in the free-living cervids of North America.

Sikes et al. (1972) described the serum changes in a white-tailed deer in response to rheumatold arthritis. Woolf et al. (1973) compared electrophoretic patterns of normal bighorn sheep with those suffering from chronic pneumonia and concluded that the values they obtained for albumin of bighorn sheep by electrophoresis were more accurate than those obtained by chemical methods.

Leland et al. (1958) described electrophoretic fractionation of serum from calves experimentally infected with Trichostrongylus axei, a nematode which I found in the elk of study (Chapter VIII). Leland et a1. (1959) continued work in serum protein responses to $\underline{T}$ axei infection in calves and subsequently found (Leland et al. 1961) that serum proteins in lambs demonstrated a different response to infection with T. axei from that observed in calves. Leland et al. (1966) presented data from serum protein changes to counter the theory that improved nutrition effectively negates the influence of nematode infection in calves. Leland (1969) reviewed the work of various investigators who have studied the relationship between helminthic diseases and proteins in anima1s. I.ittle change in the gamma globulin fraction was found 
with virus infections of cattle and sheep by Campbell (1960). In comparing clinically parasitized, moderately parasitized, and non-parasitized lambs, Kuttler and Marble (1960) found slgnificant differences in the alpha ${ }_{1}$, alpha $a_{2}$, and beta globulins. The nematode species recovered at necropsy of parasitized lambs by Turner and Wilson (1962) included species that are commonly found in elk. The authors found that helminthfree lambs had consistently higher albumin/globulin ratios and lower globulin percentages than did lambs with naturally acquired gastrointestinal parasites.

METHODS AND MATERIALS

Blood samples were obtained at the time of death from 22 hunterkilled Roosevelt elk in southwestern Oregon. Blood samples suitable for serum analysis were also obtained by the methods described in Chapter III from 72 of the 82 living elk listed in Table II. Blood was allowed to clot and centrifuged for 15 minutes at 3,500 RPM for separation of serum.

Ages for the free-living elk were determined from dentition by the eruption and wear method of Quimby and Gaab (1957), and for the captive elk were established from animal records.

Electrophoresis of serum protelns for this study was done on Titan III cellulose acetate strips, $1^{\prime \prime} \times 3^{\prime \prime}$, manufactured by Helena Laboratorles, Beaumont, Texas. The apparatus employed was a Helena Chamber with Gelman Power Supply manufactured by Ge1man, Ann Arbor, Michigan, and operated at 210 volts for twelve minutes at ambient temperature. Because an increase in electric current rould result in an increase in 
temperature, the operation was maintained at a range of five to fifteen milliamps. The buffer solution had $\mathrm{a}$ pH of 8.6 and was prepared using $10.6 \mathrm{~g}$ sodium diethy 1 barbiturate ("Barbital Sodium") and $1.5 \mathrm{~g}$ diethyl barbituric acid ("Barbital Merck") combined with sufficient distilled water to yield $1,000 \mathrm{ml}$. The staining procedure consists of Ponceau stain for two minutes, followed by three rinses with $5 \%$ glacial acetic acid of two minutes each. A dehydration step of $1 \frac{1}{2}$ minutes of absolute methanol was followed by a clearing step of $1 \frac{1}{2}$ minutes with a solution of absolute methanol and commercial strength dimethyl sulfoxide in a 1:10 ratio. The strips were then air dried for two minutes under a fan and hood, followed by oven drying for five minutes at approximately $100^{\circ} \mathrm{C}$. The stained strips were scanned with a Mililpore densitometer and the percentage ō each fraction was calculated. Fractions were arbitrarily designated albumin and alpha $a_{1}$ alpha $a_{2}$ beta, and gamma globulin in order of fastest to slowest mobilities. Albumin to globulin (A/G) ratios were compuced from the electropheretic scan.

Total serum protein values, based on the Biuret reaction, were obtained from the Technicon SMA AutoAnalyzer reading for that component. Sera from seven of the nine Seattle zoo elk were tested for the presence of the antitrypsin enzyme by the State of Oregon laboratory for the study of metabolic disorders under the direction of $\mathrm{Mr}$. Gatlin Brandon.

Serum protein data have been summarized and grouped for a comparison of values obtained at death and from living elk, as well as to facilitate comparison between young and old elk in captivity, and between young and old free-1iving elk. 
RESULTS

Data obtained by analysis of serum from 72 1iving elk and 22 recently shot elk of mixed ages and sexes are summarized in Table XII and XIII.

A summary of albumin values for 19 male and 53 female elk of mixed ages are given in Table XIV.

When 5 captive animals under two years of age were compared with 11 captive animals two years of age and older for total protein, albumin, total globulins, and albumin/globulin ratios (Table XV), relatively large differences were seen.

Stmilarly, a comparison of 27 young and 29 old free-living elk disclosed major differences for concentrations of total protein, albumin, total globulin, and for albumin/globulin ratios (Table XVI). Mean values for total protein, albumin, total globulins and albumin/globulin ratio are given in Table XVII for elk of six categories -- living, dead, captive young, captive old, free-living young, and free-living old.

DISCUSSION

For many studies of blood physiology in members of the deer family, samples have been obtained from dead or dying animals (Wilber and Robinson 1958; Rosen and Bischoff 1952; McDougall and Lowe 1968; Seal and Erickson 1969; Browman and Sears 1955). To demonstrate the potential effect arising from this variable, data for serum proteins are presented here for blood samples taken from 22 elk 1mmediately after 
TABLE XII

SUMMARY OF SERUM PROTEIN VALUES

FOR DEAD AND LIVING ELK

At Death

Iiving

TOTAL PROTEIN ( $\mathrm{g} \%$ )

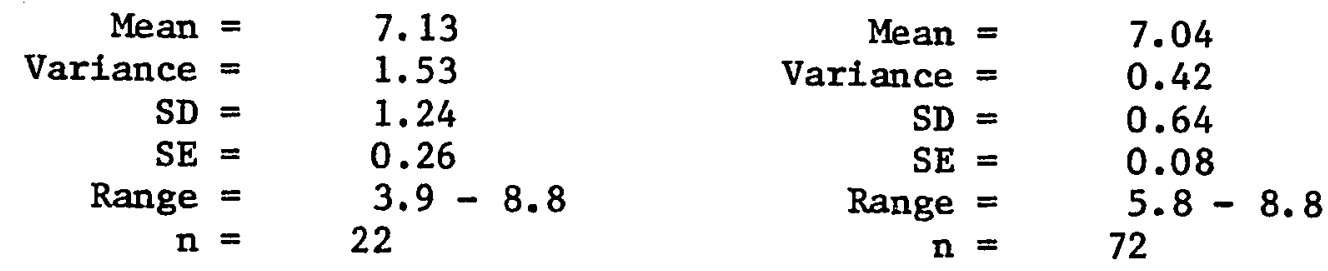

ALBUMIN (g\%)

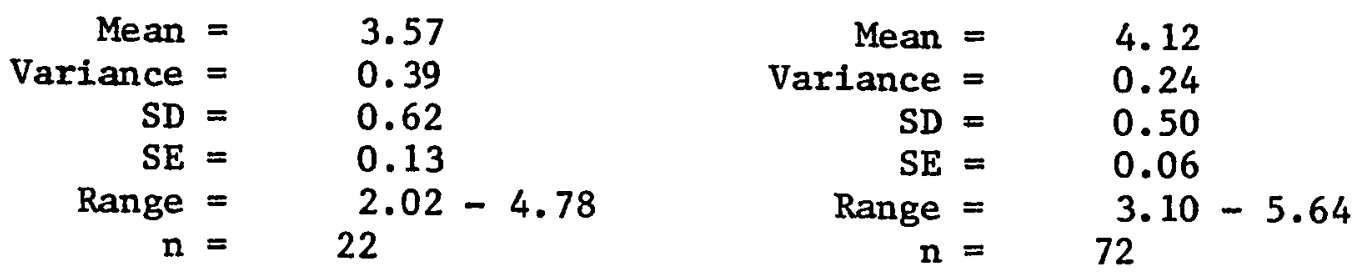

TOTAL GLOBULIN ( $g \%)$

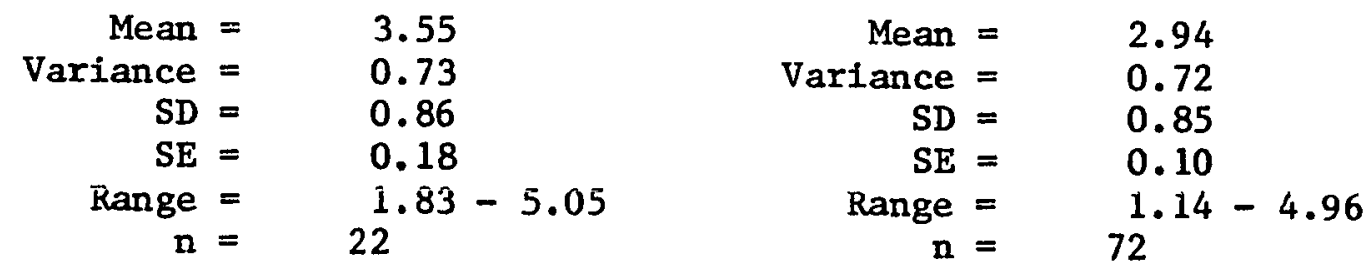

ALBUMIN/GLOBULIN RATIO

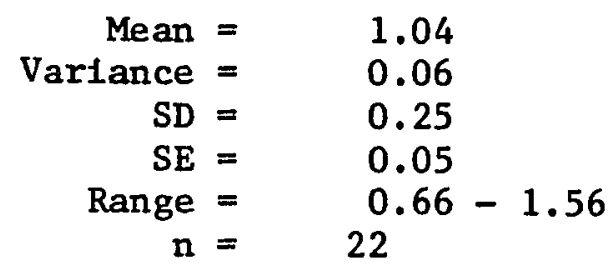

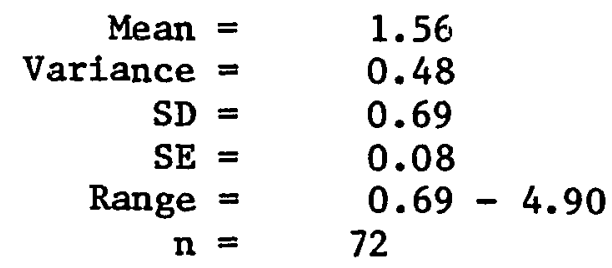


TABLE XIII

SUMMARY OF SERUM GLOBULIN VALUES

FOR DEAD AND LIVING ELK

At Death

Living

ALPHA $_{1}$ GLOBULIN (g\%)

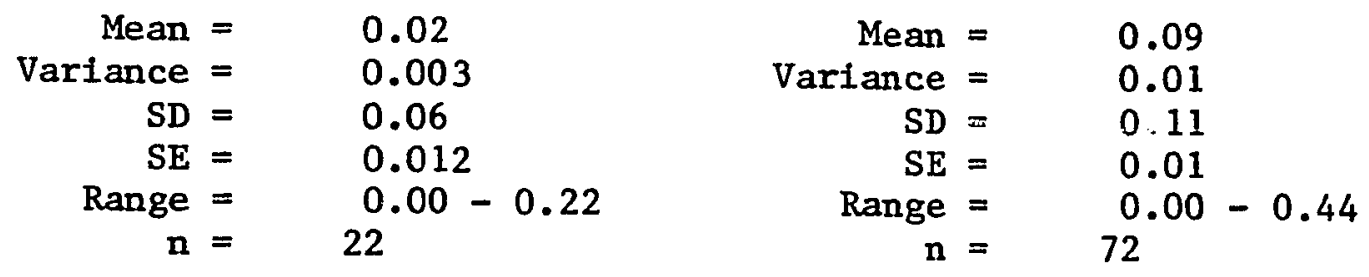

ALPHA $_{2}$ GLOBULIN (g\%)

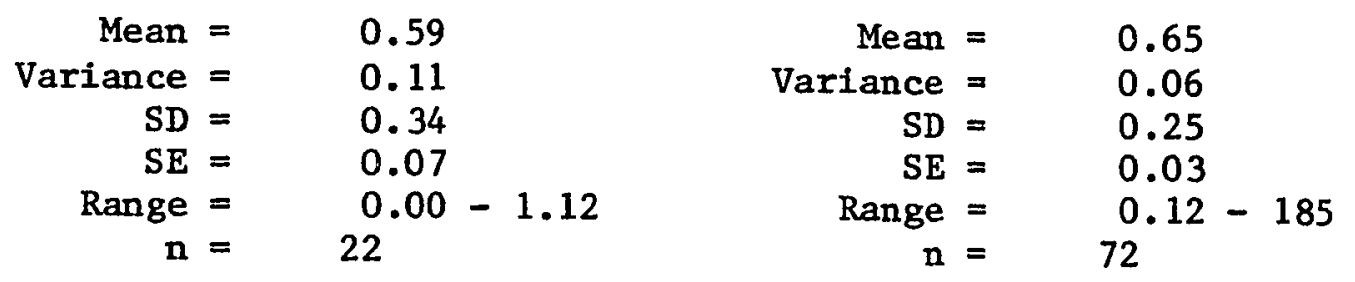

BETA GLOBULIN（g\%）

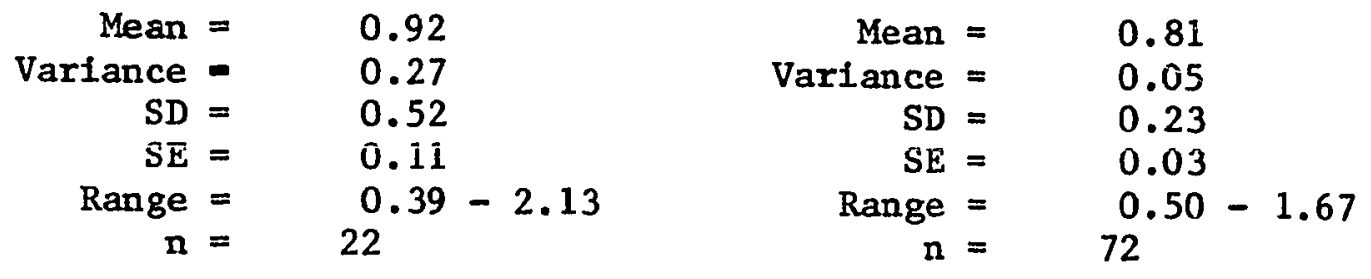

GAMA GLOBULIN (g\%)

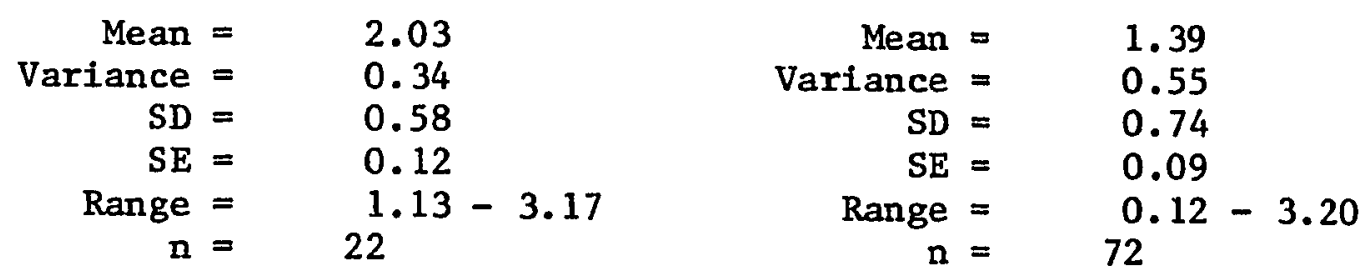


TABLE XIV

\section{ALBUMIN ( $\mathrm{g} \%$ ) CONCENTRATIONS}

FOR MALE AND FEMALE ELK

Males

$\begin{aligned} \text { Mean } & =4.29 \\ \text { Variance } & =0.26 \\ \text { SD } & =0.51 \\ \text { SE } & =0.12 \\ \text { Range } & =3.41-5.64 \\ \mathrm{n} & =19\end{aligned}$

Females

$$
\begin{aligned}
\text { Mean } & =4.05 \\
\text { Variance } & =0.23 \\
\mathrm{SD} & =0.48 \\
\mathrm{SE} & =0.06 \\
\text { Range } & =3.10-5.18 \\
\mathrm{n} & =53
\end{aligned}
$$


TABLE XV

\section{SUMMARY OF SERUM PROTEIN VALUES FOR TWO AGE GROUPS OF CAPTIVE ELK}

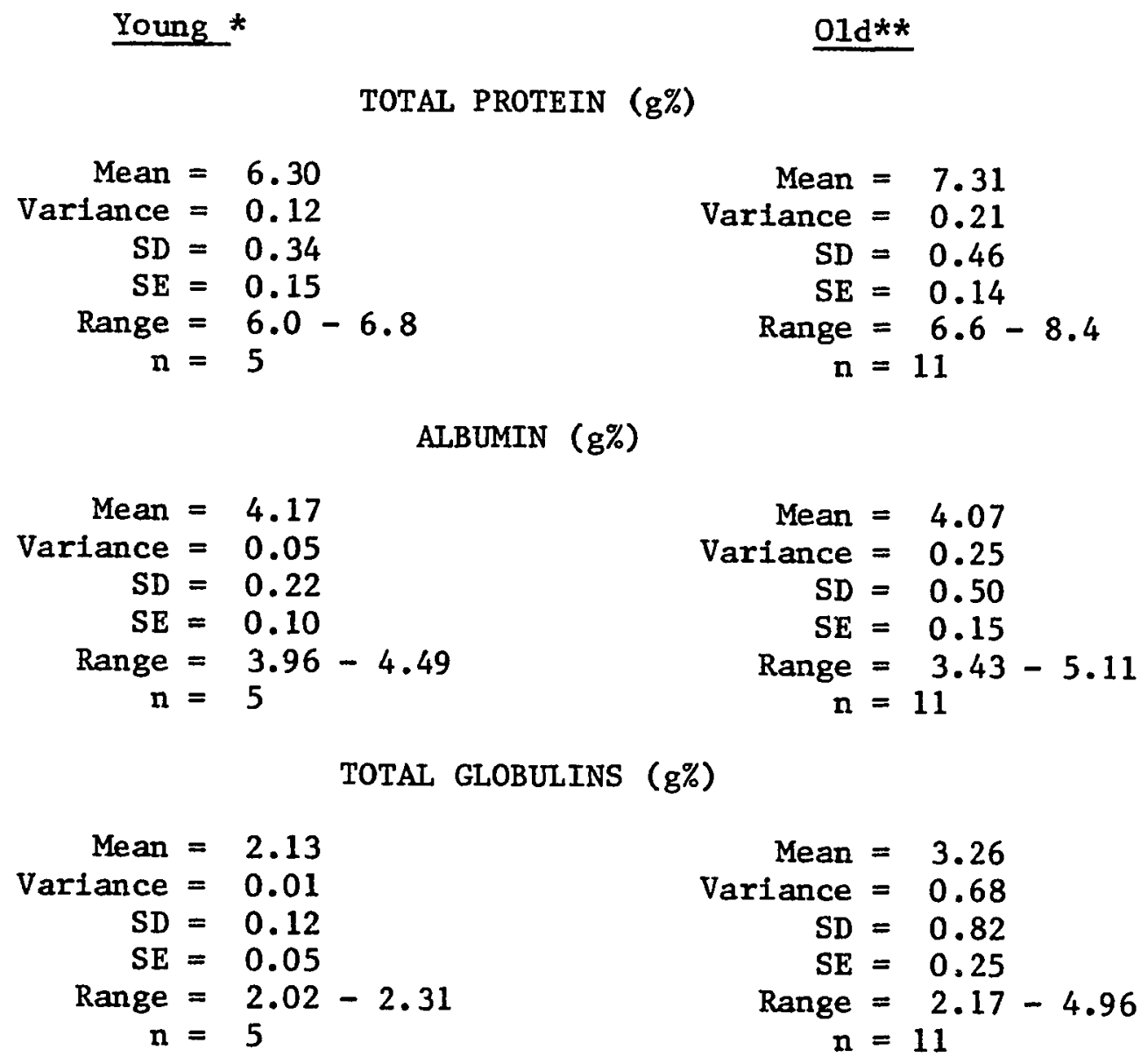

ALBUMIN ( $\mathrm{g} \%)$

$$
\begin{aligned}
\text { Mean } & =4.07 \\
\text { Variance } & =0.25 \\
\mathrm{SD} & =0.50 \\
\mathrm{SE} & =0.15 \\
\text { Range } & =3.43-5.11 \\
\mathrm{n} & =11
\end{aligned}
$$

TOTAL GLOBULINS ( $\mathrm{g} \%$ )

ALBUMIN/GLOBULIN RATIO

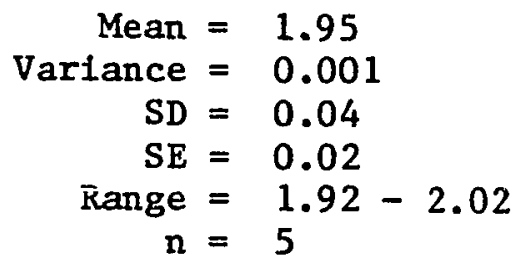

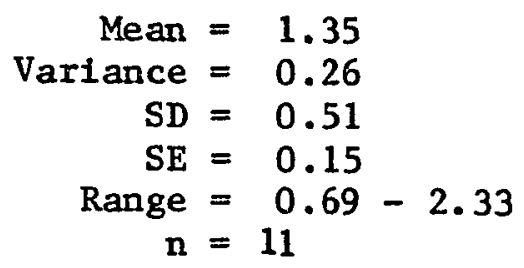

* Young elk are less than two years of age ** 01d elk are two years of age and older 
TABLE XVII

MEAN VALUES FOR SERUM PROTEINS

FOR SIX CATEGORIES OF ELK

\begin{tabular}{cccc} 
Total Protein $(\mathrm{g} \%)$ & Albumin $(\mathrm{g} \%)$ & Total Globulins $(\mathrm{g} \%)$ & A/G Ratio \\
\cline { 2 - 3 } 7.13 & 3.57 & 3.55 & 1.04 \\
7.04 & 4.12 & 2.94 & 1.56 \\
6.30 & 4.17 & 2.13 & 1.95 \\
7.13 & 4.07 & 3.26 & 1.35 \\
6.75 & 4.33 & 2.41 & 1.98 \\
7.34 & 3.92 & 3.44 & 1.20
\end{tabular}


death and are presented with similar data from 72 living elk.

The values for total protein, and for alpha 2 and beta globulins appear to be affected the least by post-mortem change. Values for albumin, alpha 1 and gamma globulins were greatly different between dead and living elk. The total globulin and albumin/globulin ratio values also differed markedly between the two categories.

In presenting the values obtained from the living elk as baseline or "normal", it should be noted that not only does an animal's "normal" total serum protein level show change under the influence of pregnancy and parturftion (Youatt et al. 1965; Larson and Touchberry 1959), stage of growth (Bandy et al. 1957) and season of year (Matthews 1968; Seal and Erickson 1968), but the ratios of the specific proteins may also change (Bandy et al. 1957).

The total protein value I obtained $(7.01 \pm 0.40 \mathrm{~g} \%)$ is within the range of the data of Post (1957) for elk in Wyoming. He reported values for eleven elk in February with a mean of 7.4 and range of 6.6 to 8.6 $\mathrm{g} \%$, and for ten elk in May with a mean of 6.1 and range of 4.8 to 6.8 $g \%$

Albanese et al. (1958) demonstrated that total protein levels in the blood failed to reflect a deficiency of protein in the diet. This effect is due to the "tissue-robbing" property of the blood. It has been sald that during a period of prolonged inadequate nutrition, the herbivore becomes a carnivore, utilizing his body protein reserves as the source from which serum proteins, as well as hemoglobin, are manufactured (Maynard and Loosil 1969:148). Although total serum protein may remain constant, a change in the proportions of albumin and globulins 
can provide an index to nutritional status (Chow 1947). A drop in serum albumin is a sensittve indicator of decreased protein intake (Maynard and Loos11 1969:149).

The ruminant has a remarkable advantage over the monogastric animal in the matter of protein metabolism. Not only are the rumen microorganisms capable of supplying amino actds to their host while themselves being nourished on low-quality forage, but also the rumen receives urea from the blood by diffusion through the rumen wall, and by way of the saliva, during periods of limited nitrogen intake. This urea recycling may he considered as a protein regeneration cycle, since the urea diffused into the rumen is used for amino acid synthesis in the same manner as dietary urea (Church et al. 1971:578). Despite these advantages, Murphy and Coates (1966) found a direct relationship between three levels of dietary protein intake and productivity in female whitetailed deer. Fawns were produced by females on $7 \%$ and $11 \%$ protein diets, but died of malnutrition due to inadequate lactation by the females.

A marked decrease in total plasma protein, associated in turn, with edematous sweliings of the neck and jaw, can occur in cattle suffering from trichostrongylidosis (Schalm 1965), a type of parasitism to which elk are also subfect (Chapter VIII). Whether a reduction of serum protein to the clinically pathological levels seen in severely infected cattle would also occur in elk is not known.

The mean albumin value I obtained $(4.12 \mathrm{~g} \% \pm 0.50 \mathrm{SD})$ is substantially higher than the $2.25 \mathrm{~g} \% \pm 0.999 \mathrm{SD}$ reported for elk by Herin (1968). My high albumin value probably reflects the fact that mañy yearling freewliving elk, which have the high serum albuinin levels 
characteristic of young animals, are included in my sample. In examining serum protein data from other wild ruminants, I found the albumin values reported for Rocky Mountain bighorn sheep in captivity (Woolf and Kradel 1970) to be similar to those reported here for elk. From a more closely related species, LeResche and Davis (1971) reported albumin values for moose during fall rut season, early winter, spring, and summer to be $5.07 \pm 0.50 \mathrm{SD}, 3.76 \pm 0.55 \mathrm{SD}, 4.66 \pm 0.51 \mathrm{SD}$, and 4.98 $\pm 0.69 \mathrm{SD} g \%$, respectively. Ages were not given for the moose.

The globulin value reported here $(2.94 \mathrm{~g} \% \pm 0.85 \mathrm{SD})$ is lower than the mean globulin of $3.39 \mathrm{~g} \% \pm 1.45 \mathrm{SD}$ reported by Herin (1968) with a low of 0.99 and a high of $6.93 \mathrm{~g} \%$. The values I obtained from 72 living elk were markedly more uniform and are well within the wide range Herin reported for this species. Bandy et al. (1957) found mean values of 1.08 to $4.69 \mathrm{~g} \%$ for plasma globulin in Columbian black-tailed deer.

The A/G ratio I found ( $1.56 \pm 0.69 \mathrm{SD})$ can be compared with a mean of $0.67 \pm 0.099 \mathrm{SD}$ reported by Herin (1968) who observed that his low value could be due to the stressed condition of the elk and that a low $A / G$ Iatio is sometimes seen in strassed animals.

For 34 of the 72 livirig elk studied, no reading at the alphal globulin fraction could be obtained. This was true for ail nine of the Woodland Park elk, and 13 of the 38 elk from Wallowa County. The Wallowa County group, on the other hand, included a yearling female with a $0.44 \mathrm{~g} \%$ alpha 1 globulin concentration.

of interest in this connection is the finding that the absence of the alpha globulin fraction in humans is associated with antitrypsin 
deficiency and an inherited pattern of pulmonary disorders (Hammarsten et al. 1971; Lieberman et a1. 1969). The antitrypsin enzyme deficiency test, which is qualitative rather than quantitative, demonstrated activity of the enzyme in seven captive elk which were tested, despite the absence of an alpha globulin fraction analogous to that in which the enzyme is found in humans.

Studies of white-tailed deer (Tumbleson et al. 1968; Youatt et al. 1965) reported the alpha $_{1}$ and $a \mathrm{pha}_{2}$ globulins as a combined value, at levels similar to those in elk when the values are also combined. Although data are not available for comparison with other elk, the beta globulin value I found $(9.81 \mathrm{~g} \% \pm 0.23 \mathrm{SD})$ is similar to that reported for white-tailed deer (Tumbleson et al. 1968).

The gamma globulin fraction shows considerable variability whtch could reflect the extent to which the different animals have been challenged with antigenic agents (Tumbleson et al. 1968). An 11lustration of the varlability for this parameter seen in the literature is the mean gamma globulin value reported by Seal and Erickson (1969) of 0.75 $\mathrm{g} \% \pm 0.10 \mathrm{SD}$ for one group of adult female white-tailed deer collected by shooting and the value of $1.08 \mathrm{~g} \% \pm 0.43 \mathrm{SD}$ reported by Tumbieson et a1. (1968) for another group of three-year-old females of the same species for which the method of collection is not discussed. An increase In serum gamiáa globulin concentration for black-talled deer from 5 to 15 months of age was reported by Cowan and Johnson (1962).

The serum albumin values given for male and female elk (Table XIII) include captive and free-living animals of mixed ages. The difference found indicates an apparent tendency to higher albumin levels 
among males of this species. This finding is supported by the reports of higher levels of serum albumin for males in the chimpanzee and gorilla described by Planas and Grau (1971), and in black-tailed and white-tailed deer discussed by Cowan and Johnson (1962).

Total serum protein concentrations were markedly higher in the older age groups of both captive and free-living elk. This pattern of age-related increase has been reported in mule deer (Anderson et al. 1972), Columbian black-tailed deer (Bandy et al. 1957), white-tailed deer (Seal and Erickson 1968), and bovines (Larson and Touchberry 1959; Dimopoullos 1961; Tumbleson et a1. 1962). Electrophoretic studies of the serum proteins of animals at different ages have shown important differences and shifts with maturation, espectally when the very young are included. This has been found in horses (Polson 1943), in dairy cattle (Mylrea and Healy 1968), in black-tailed deer (Bandy et al. 1957), In moose (Houston 1969), and other species (Riegle and Nellor 1966). The relatively constant concentration of total serum protein that is maintained in homeostasis requires an increase in globulin be accompanied by a decrease in albumin. With increased age, there may be less synthesis of the labile protein pool of which aibumin is a component (Tumbleson et al. 1968).

Influences arising from captivity were believed to be responsible for serum protein differences observed in deer species studied by Van Tets and Cowan (1966). Their findings are in agreement with the study of Weber and Bliss (1972) In which differences were described between captive and free-living Rooseve1t elk. For the animals in their study, Weber and Bliss reported that albumin was significantly higher in 
captive than in free-living elk, and showed less difference with age. Weber and bliss further found that globulin was significantly higher in free-living elk, as might be expected from exposure to injurious agents in the wild environment, and somewhat higher globulin concentrations were found in mature elk when compared with calves. As described in Chapter IX, globulin response to tick infestation among the elk from southwestern Oregon may have had an influence on the serum protein values obtained for the free-living Roosevelt animals studied by Weber and Bliss.

Endoparasites are known to exert an influence on the animal that is reflected in reduced albumin, reduced total protein, increased globulin, and reduced albumin/globulin ratios (Turner and Wilson 1962; Kuttler and Marble 1960). Grobov (1961) found a decline in albumin and increase in beta globulin in elk infected with the blood parasite, Anaplasma. Extensive work by Leland (1961) and by Leland et al. (1958, 1959, 1960 and 1966) has elucidated the marked impact of helminthic diseases upon the serum proteins of domestic ruminants. The parasites which Leland and his co-workers found to exert a significant influence incIude Dictyocaulus, Ostertagia, Trichostrongyius axei, and Oseophagostomum. Adults of all four of these genera were recovered from freeliving Roosevelt elk in my study (Chapter VIII). Eggs of the latter three parasite species were recovered from fecal pellets taken directly from both the free-living and captive elk at the time the animals were immobilized and blood samples were drawn (Chapter VIII). It was not possible to obtain blood samples from living elk known to be free of gastrointestinal parasites. It is 1ikely that a serum protein response 
to the presence of these nematodes occurs in elk as it does in cattle and sheep, but that hypothesis remains to be tested.

Gamma globulin levels for the 24 elk represented in Table XII, Chapter VII, were compared with levels established as baseline for this serum protein fraction. The mean level for the elk which exhibited evidence of past infection with leptospires was found to be no higher than the mean for living elk generally.

CONCLUSIONS

The values I propose as baseline or "normal" for total protein, albumin, alpha ${ }_{1}$ alpha 2 , beta and gamma globulin, total globulins, and albumin/globulin ratio are presented for elk.

The data supplied here make it possible to evaluate the ways in which serum protein values obtained from recently killed elk can be expected to differ from those obtained from living animals. The comparatively small difference noted in total serum protein values supports the view that data for that parameter collected from deer at death may be useful. The separate protein fractions and A/G ratio, however, appear to be subject to greater post-mortem change.

Carefully selected samples of male and female elk adjusted for age which have all been reared in captivity or which are all free-living would be necessary to verify the apparent trend I found toward higher albumin values for the males of this species.

Serum protein values for both captive and free-living elk of two age categories are summarized.

Just as Turner and Wilson (1962) expressed the opinion that serum 
protein values for "normal" or "clinically sound" sheep on pasture are values modified by parasitic infection in relatively resistant or immune animals, so also does the wide spread incidence of helminth eggs recovered from elk in this study lead me to a similar conclusion with respect to the values I obtained. 
CHAPTER VI

SERUM CHEMISTRY

With the development of automated analytical equipment utilizing whole blood and serum, it has become possible to test rapidly for the presence of a larger number of biochemical parameters than was previously practical. Such analyses can be done while elk are being held for transplant purposes or in zoo exhibit groups. The value of serum analysis depends upon the establishment of normal ranges for the various components, in order that normal elk physiology can be understood and deviations reflecting poor nutrition and pathological conditions can be detected.

Limited data are available on the chemistry of elk blood. During his work on the rumen physiology and parasitology of elk, McBee (1964) analyzed for some blood constituents in eleven elk of mixed ages and sexes. Many of the components I studied were also examined by Herin (1968) for Rocky Mountain elk and their blood levels compared with those of domestic ungulates. Reporting on a limited number of chemical constituents of elk blood, Knight (1969) cited the lack of similar data from other herds, and the imperfect knowledge of elk physiology. Weber and Bliss (1972) studied the blood chemistry of Roosevelt elk and provided the first information for the West Coast subspecies.

Job completion and progress reports for projects financed by the Federal Aid in Fish and Wildlife Restoration Act (Pittman-Robertson Act) may be obtained directly from state fish and game departments. Post (1953) sought to determine normal values for several blood constituents 
of deer, elk and antelope; he later (1957) correlated his clinical observations with elk nutrition. Blunt (1959) studied the nutritive value of flavonoid compounds in elk rations. Citrus pulp was used at the Sybille Wildlife Research Unit in Wyoming for emergency winter feed, and data were obtalned for eight blood constituents to evaluate the success of the experimental feeding program. Greer and Picton (1964) analyzed for minerals and vitamins in the serum of elk from the Yellowstone, Gallatin and Sun River herds of Montana, and used the physiological data they obtained to assess the quality of forage intake, the impact of environmental stress, and the physical condition of the animals in these three herds. Subsequently, Greer (1965a) reported on further blood studies from the Gardiner herd, and (1965b) from the Gallatin herd, of elk that winter in Yellowstone National Park. Each of the above investigators used a small number of animals.

Studies of the blood chemistry of other species which I found of value include the work of Graham et al. (1962) who described alterations of deer blochemistry concurrent with antler growth. Matthews (1968) was unable to find a reflection of nutritional status in the limited number of blood parameters he examined for white-tailed deer. Seal and Erickson (1969a) described high blood glucose levels in white-tailed deer subjected to acute stress. Tumbleson et al. (1968a) discussed the use of automated analytical methods in the study of animal physiology, and (Tumbleson et al. 1968b) reported on biochemical studies of serum from white-talled deer in Missour1. Houston (1969) found variations in the serum chemistry of 13 Shiras moose at different times of the year= Tumbleson et al. (1970a) provided both biochemical and hematological 
data for captive white-tailed fawns. Anderson et al. (1972) analyzed the effects of shock and excitement in their study of serum electrolytes in a Colorado mule deer population. Seal et al. (1972b) examined the influence of nutrition on thyroid activity and blood values in whitetailed deer.

The investigations of LeResche and Davis (1971) involve moose, for which the authors seek to establish baseline data for the same range of blood values which $I$ am examining in elk. For their analyses, LeResche and Davis are using the Technicon AutoAnalyzer, to correlate blood values with season, age, and sex.

Looking for physiological differences which enable two different breeds of cattle to survive in their respective environments, olbrich et al. (1971) studied the biochemistry and hematology of heat-tolerant Zebu and cold-tolerant Scotch Highland heifers. Tumbleson et al. (1973a) discussed the relationship between aging and serum electrolyte concentrations in female dairy cattle. Mylrea and Healy (1968) reported an apparent increase in serum glutamic oxalacetic transaminase activity with age in dairy cattle. Wolff et al. (1969) described the differences in serum chemical values they found when comparing 77 normal and diseased horses.

METHODS AND MATERIALS

Blood samples were obtained and the serum removed as previously described. Values for serum concentrations of sodium, potassium, calclum, Inorganic phosphorus, blood urea nitrogen (BUN), chlorides, cholesterol, glucose, direct bilirubin, total bilirubin, creatinine, and 
uric acid, as well as values for activity levels of alkaline phosphatase, lactic dehydrogenase (LDH), and serum glutamic oxalacetic transaminase (SGOT) were obtained by use of the Technicon SMA AutoAnalyzer operated by Pathologists Central Laboratory, Inc., 1406 S.E. Stark Street, Port1and, Oregon, under the direction of T. H. Cochran, M.D. Sodium/potassium and calcium/phosphorus ratios were calculated.

Appendix C provides a detailed discussion of the analytical methods adapted for the Technicon SMA AutoAnalyzer with references for the procedures employed.

Urine specimens were obtained from seven elk and analyzed for the presence of glucose by use of prepared reagent strips (Bili-Lab Stix, Ames Company, Division of Miles Laboratory, Elkhart, Indiana).

Serum chemistry data were summarized and grouped to facilitate examination of values obtained for living elk and elk at death, for young and old captive elk, and for young and old free-living elk.

\section{RESULTS}

Tables XVII through XXII contain a summary of the values for 22 elk at death and for 72 living elk of mixed ages and sexes. Sixteen of the seventeen parameters being examined showed a sizeable difference between living and dead elk. Values for cholesterol are nearly identical for the two categories.

Glucose values for lactating and non-lactating female elk showed lower serum levels in the lactating group (Table XXIII).

Values for the serum components and ratios were grouped on the basis of age for captive elk (Tables XXIV through XXVIII), and for free- 
TABLE XVIII

\section{SUMMARY OF VALUES FOR THREE SERUM MINERALS \\ IN DEAD AND LIVING ELK}

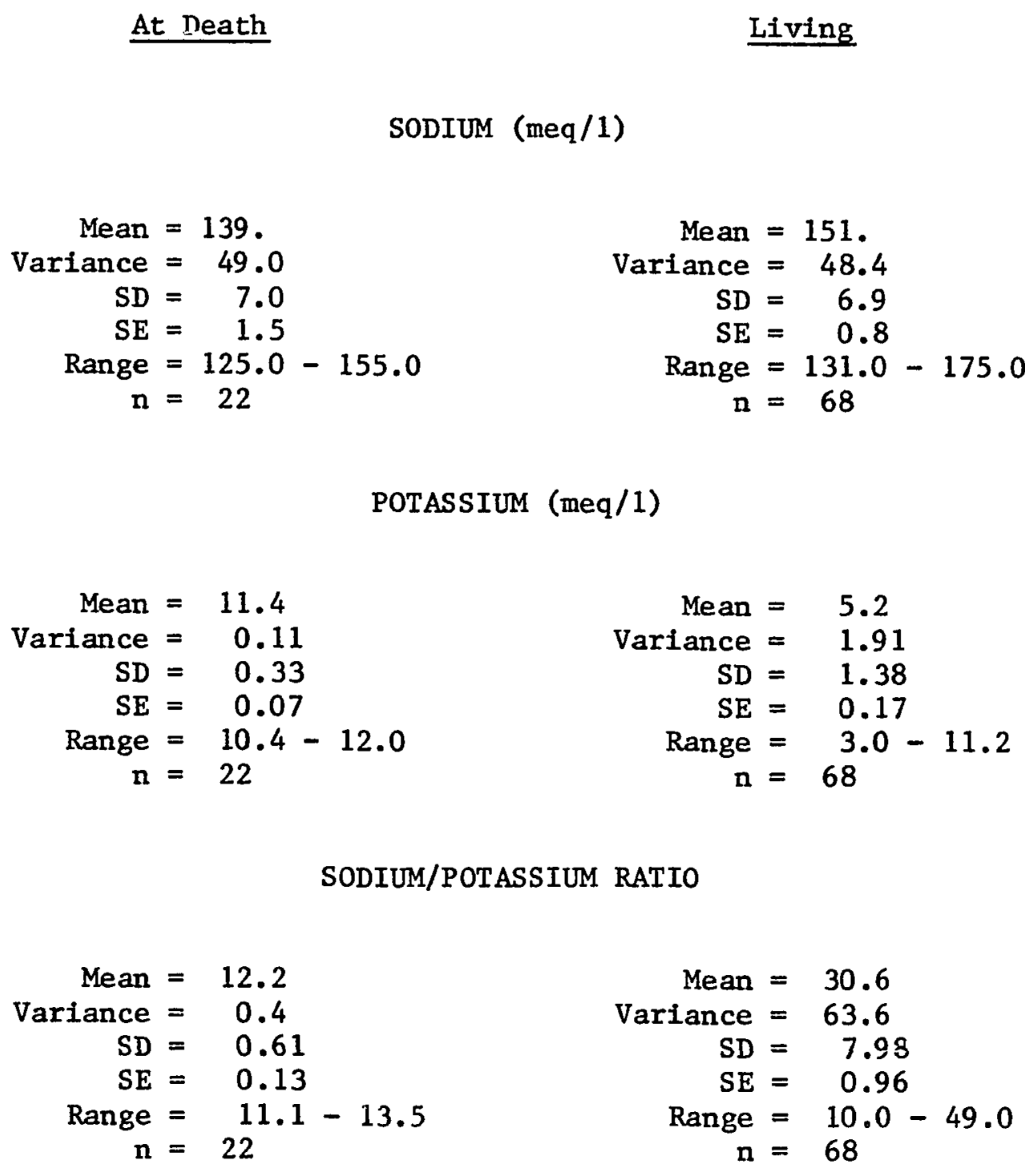

At Death

Living

Mean $=11.4$

Variance $=0.11$

$\mathrm{SD}=0.33$

$S E=0.07$

Range $=10.4-12.0$

$\mathrm{n}=22$

$$
\begin{aligned}
\text { Mean } & =5.2 \\
\text { Variance } & =1.91 \\
\mathrm{SD} & =1.38 \\
\mathrm{SE} & =0.17 \\
\text { Range } & =3.0-11.2 \\
\mathrm{n} & =68
\end{aligned}
$$

\section{SODIUM/POTASSIUM RATIO}

Mean $=12.2$

Variance $=0.4$

$\mathrm{SD}=0.61$

$\mathrm{SE}=0.13$

Range $=11.1-13.5$

$\mathrm{n}=22$

$$
\begin{aligned}
\text { Mean } & =30.6 \\
\text { Variance } & =63.6 \\
\mathrm{SD} & =7.98 \\
\mathrm{SE} & =0.96 \\
\text { Range } & =10.0-49.0 \\
\mathrm{n} & =68
\end{aligned}
$$


TABLE XVIX

SUMMARY OF VALUES FOR THREE SERUM MINERALS

IN DEAD AND LIVING ELK

At Death

Living

CALCIUM (mg\%)

$\begin{aligned} & \text { Mean }=7.7 \\ & \text { Variance }=5.57 \\ & \text { SD }=2.36 \\ & \text { SE }= 0.50 \\ & \text { Range }= 3.1-12.2 \\ & \mathbf{n}=22\end{aligned}$

Mean $=7.7$

$\mathrm{n}=22$

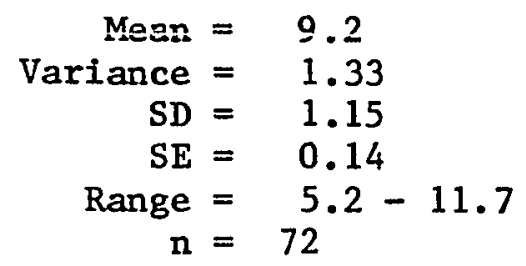

INORGANIC PHOSPHORUS (mg\%P)

$$
\begin{aligned}
\text { Mean } & =5.5 \\
\text { Variance } & =4.16 \\
\text { SD } & =2.04 \\
\text { SE } & =0.24 \\
\text { Range } & =1.6-12.4 \\
\mathrm{n} & =72
\end{aligned}
$$

\section{CALCIUM/PHOSPHORUS RATIO}

$$
\begin{aligned}
\text { Mean } & =0.96 \\
\text { Vartance } & =0.05 \\
\mathrm{SD} & =0.23 \\
\mathrm{SE} & =0.05 \\
\text { Range } & =0.41-1.34 \\
\mathrm{n} & =22
\end{aligned}
$$

$$
\begin{aligned}
\text { Mean } & =1.97 \\
\text { Vartance } & =1.38 \\
\mathrm{SD} & =1.18 \\
\mathrm{SE} & =0.14 \\
\text { Range } & =0.84-5.09 \\
\mathrm{n} & =72
\end{aligned}
$$


TABLE XX

\section{SUMMARY OF VALUES FOR FOUR SERUM COMPONENTS \\ IN DEAD AND LIVING ELK}

$\begin{array}{rlrl}\text { At Death } & \text { Living } \\ \text { BLOOD UREA NITROGEN (mg\%) } & \\ \text { Mean }=5 . & \text { Mean }= & 24 . \\ \text { Variance }=21.9 & \text { Variance }= & 42.7 \\ \text { SD }=4.7 & \text { SD }= & 6.5 \\ \text { SE }=0.9 & \text { SE }= & 0.7 \\ \text { Range } & =0.0-14 . & \text { Range } & =11 .-44 . \\ \text { n } & =22 & \text { n } & =72\end{array}$

CHLORIDES (meq/1)

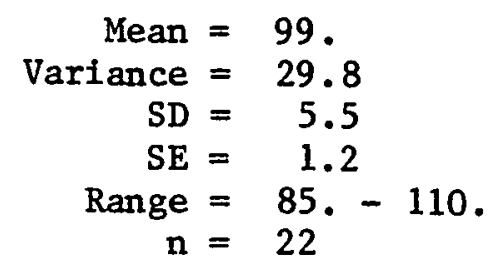
Mean $=105$.
Variance $=\quad 47.9$
$\mathrm{SD}=\quad 6.9$
$\mathrm{SE}=0.8$
Range $=85 .-125$.
$\mathrm{n}=68$

CHOLESTEROL (mg\%)

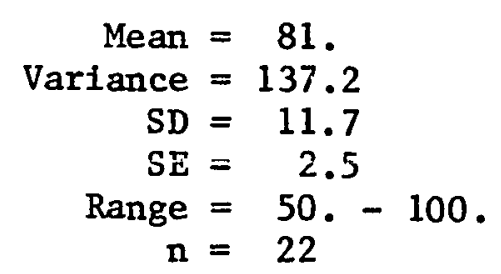

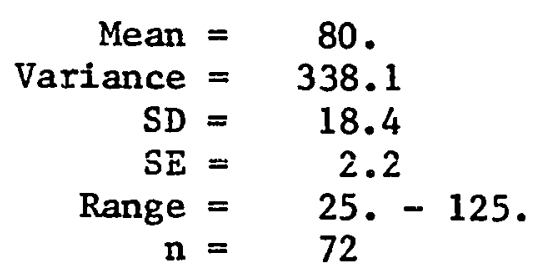

GLUCOSE (mg\%)

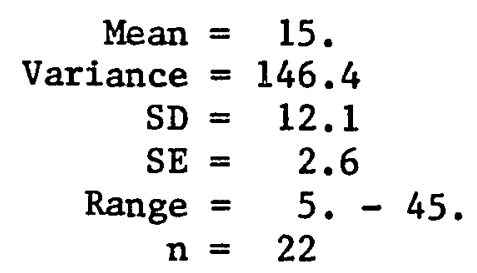

$$
\begin{aligned}
& \text { Mean }=192 . \\
& \text { Variance }=6,481.5 \\
& \mathrm{SD}=80.5 \\
& \mathrm{SE}=9.7 \\
& \text { Range }=15 .-450 \text {. } \\
& \mathrm{n}=69
\end{aligned}
$$


TABLE XXI

SUMMARY OF VALUES FOR FOUR

SERUM METABOLIC BY-PRODUCTS

IN DEAD AND LIVING ELK

At Death

Living

DIRECT BILIR̄ÜBIN (mg\%)

$$
\begin{aligned}
\text { Mean } & =0.0 \\
\text { Variance } & =0.001 \\
\mathrm{SD} & =0.035 \\
\mathrm{SE} & =0.007 \\
\text { Range } & =0.0-0.1 \\
\mathbf{n} & =22
\end{aligned}
$$

$$
\begin{aligned}
\text { Mean } & =0.2 \\
\text { Vartance } & =0.007 \\
\mathrm{SD} & =0.085 \\
\mathrm{SE} & =0.010 \\
\text { Range } & =0.0-0.4 \\
\mathrm{n} & =63
\end{aligned}
$$

TOTAL BILIRUBIN (mg\%)

$$
\begin{aligned}
\text { Mean } & =0.2 \\
\text { Variance } & =0.02 \\
\mathrm{SD} & =0.14 \\
\mathrm{SE} & =0.03 \\
\text { Range } & =0.0-0.7 \\
\mathrm{n} & =22
\end{aligned}
$$

$$
\begin{aligned}
\text { Mean } & =0.9 \\
\text { Variance } & =0.18 \\
\mathrm{SD} & =0.43 \\
\mathrm{SE} & =0.05 \\
\text { Range } & =0.2-2.3 \\
\mathrm{n} & =72
\end{aligned}
$$

CREATININE (mg\%)

$$
\begin{aligned}
\text { Mean } & =2.0 \\
\text { Variance } & =0.07 \\
\mathrm{SD} & =0.27 \\
\mathrm{SE} & =0.06 \\
\text { Range } & =1.3-2.5 \\
\mathrm{n} & =22
\end{aligned}
$$

$$
\begin{aligned}
\text { Mean } & =1.5 \\
\text { Variance } & =0.14 \\
\mathrm{SD} & =0.37 \\
\mathrm{SE} & =0.04 \\
\text { Kange } & =0.6-2.9 \\
\mathrm{n} & =68
\end{aligned}
$$

URIC ACID (mg\%)

$$
\begin{aligned}
\text { Mean } & =1.0 \\
\text { Variance } & =0.54 \\
\mathrm{SD} & =0.74 \\
\mathrm{SE} & =0.16 \\
\text { Range } & =0.4-3.7 \\
\mathfrak{n} & =22
\end{aligned}
$$

$$
\begin{aligned}
\text { Mean } & =0.2 \\
\text { Variance } & =0.09 \\
\text { SD } & =0.31 \\
\text { SE } & =0.04 \\
\text { Range } & =0.1-2.1 \\
\text { n } & =72
\end{aligned}
$$


TABLE XXII

\section{SUMMARY OF ACTIVITY LEVELS \\ FOR THREE SERUM ENZYMES \\ IN DEAD AND LIVING ELK}

At Death

Living

ALKALINE PHOSPHATASE $(\mathrm{mU} . / \mathrm{ml})^{1}$

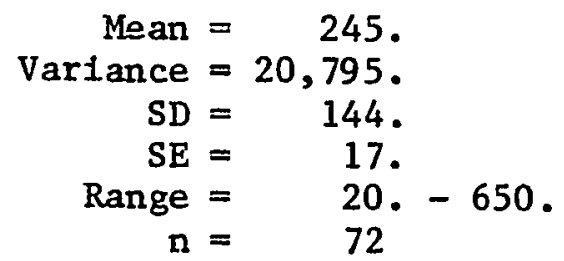

$\mathrm{n}=72$

\section{LACTIC DEHYDROGENASE $(\mathrm{mU} \cdot / \mathrm{ml})^{1}$}
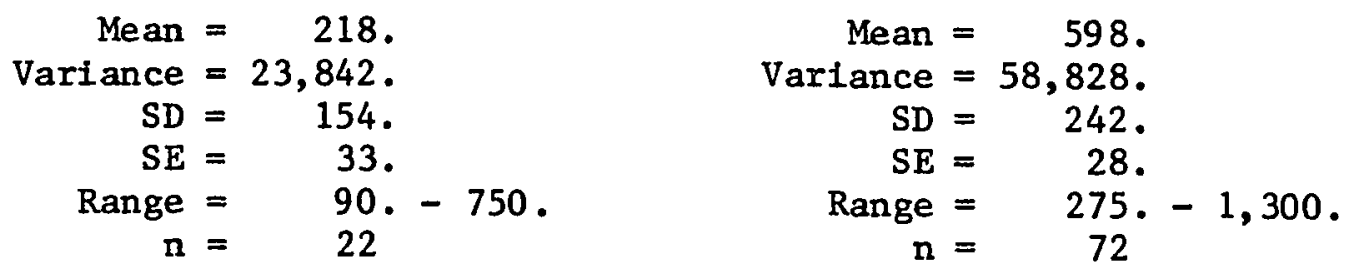

GLUTAMIC OXALACETIC TRANSAMINASE (mU./ml) 1

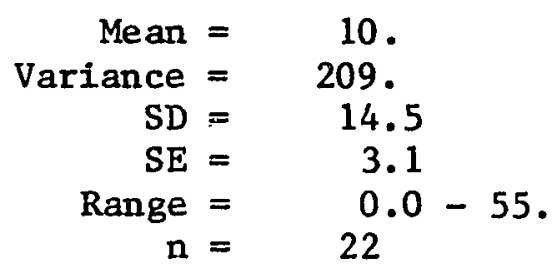

$\begin{array}{rlrl}\text { Mean } & = & 130 . \\ \text { Variance }= & 4,467 . \\ \text { SD }= & 66.8 \\ \mathrm{SE}= & 7.8 \\ \text { Range }= & 54 .-380 . \\ \mathfrak{n}= & 72\end{array}$


TABLE XXIII

\section{INFLUENCE OF LACTATION ON SERUM GLUCOSE (mg\%) CONCENTRATIONS}

Lactating Females

Mean $=186$.

Variance $=3,254.52$

$\mathrm{SD}=57.05$

$\mathrm{SE}=11.89$

Range $=45 .-275$.

$\mathbf{n}=$

23
Noñ-Lactating Females

$$
\begin{aligned}
\text { Mean } & =195 . \\
\text { Variance } & =6,817.33 \\
\mathrm{SD} & =82.57 \\
\mathrm{SE} & =16.85 \\
\text { Range } & =65 .-399 . \\
\mathrm{n} & =24
\end{aligned}
$$


TABLE XXIV

SUMMARY OF SERUM MINERAL VALUES FOR

TWO AGE GROUPS OF CAPTIVE ELK

$\underline{\text { Young* }}$

$\underline{01 d * *}$

SODIUM (meq/1)

$$
\begin{aligned}
\text { Mean } & =144 . \\
\text { Variance } & =3.8 \\
\mathrm{SD} & =1.95 \\
\mathrm{SE} & =0.87 \\
\text { Range } & =142 .-147 . \\
\mathrm{n} & =5
\end{aligned}
$$

$$
\begin{aligned}
\text { Mean } & =143 . \\
\text { Variance } & =24.9 \\
\mathrm{SD} & =4.98 \\
\mathrm{SE} & =1.50 \\
\text { Range } & =131 .-149 . \\
\mathrm{n} & =11
\end{aligned}
$$

POTASSIUM (meq/1)

$$
\begin{aligned}
\text { Mean } & =5.8 \\
\text { Variance } & =0.43 \\
\text { SD } & =0.66 \\
\text { SE } & =0.29 \\
\text { Range } & =5.1-6.7 \\
\mathrm{n} & =5
\end{aligned}
$$

$$
\begin{aligned}
\text { Mean } & =6.5 \\
\text { Variance } & =2.72 \\
\mathrm{SD} & =1.65 \\
\mathrm{SE} & =0.50 \\
\text { Range } & =4.8-11.2 \\
\mathrm{n} & =11
\end{aligned}
$$

\section{SODIUM/POTASSIUM RATION}

$$
\begin{aligned}
\text { Mean } & =25.1 \\
\text { Variance } & =7.52 \\
\mathrm{SD} & =2.74 \\
\mathrm{SE} & =1.23 \\
\text { Range } & =21.9-28.4 \\
\mathrm{n} & =5
\end{aligned}
$$

$$
\begin{aligned}
\text { Mean } & =22.0 \\
\text { Variance } & =31.31 \\
\mathrm{SD} & =5.60 \\
\mathrm{SE} & =1.62 \\
\text { Range } & =10.0-29.2 \\
\mathfrak{n} & =11
\end{aligned}
$$

* Young elk are less than two years of age

** 01d elk are two years of age and older 
TABLE XXV

\section{SUMMARY OF SERUM MINERAL VALUES FOR TWO AGE GROUPS OF CAPTIVE ELK}

Young:*

$\underline{01 \mathrm{~d} * *}$

CALCIUM (mg\%)

$$
\begin{aligned}
\text { Mean } & =10.7 \\
\text { Variance } & =0.32 \\
\text { SD } & =0.57 \\
\text { SE }= & 0.25 \\
\text { Range }= & 9.9-11.5 \\
\text { n } & =5
\end{aligned}
$$

$$
\begin{aligned}
\text { Mean } & =10.0 \\
\text { Variance } & =0.24 \\
\mathrm{SD} & =0.48 \\
\mathrm{SE} & =0.14 \\
\text { Range } & =9.2-10.8 \\
\mathrm{n} & =12
\end{aligned}
$$

INORGANIC PHOSPHORUS (mg\%P)

$$
\begin{aligned}
\text { Mean } & =8.3 \\
\text { Variance } & =0.12 \\
\mathrm{SD} & =0.34 \\
\mathrm{SE} & =0.15 \\
\text { Range } & =7.9-8.7 \\
\mathrm{n} & =5
\end{aligned}
$$

$$
\begin{aligned}
\text { Mean } & =7.8 \\
\text { Variance } & =2.53 \\
\text { SD } & =1.59 \\
\text { SE } & =0.46 \\
\text { Range } & =6.1-12.4 \\
n & =12
\end{aligned}
$$

\section{CALCIUM/PHOSPHORUS RATIO}

$$
\begin{aligned}
\text { Mean } & =1.29 \\
\text { Variance } & =0.01 \\
\mathrm{SD} & =0.11 \\
\mathrm{SE} & =0.05 \\
\text { Range } & =1.16-1.43 \\
\mathrm{n} & =5
\end{aligned}
$$

$$
\begin{aligned}
\text { Mean } & =1.32 \\
\text { Variance } & =0.04 \\
\text { SD } & =0.21 \\
\text { SE } & =0.06 \\
\text { Range } & =0.84-1.67 \\
\mathbf{n} & =12
\end{aligned}
$$

* Young elk are less than two years of age ** 01d elk are two years of age and older 
TABLE XXVI

SUMMARY OF VALUES FOR SERUM COMPONENTS

FOR TWO AGE GROUPS OF CAPTIVE ELK

$\underline{\text { Young* }}$

$\underline{01 d * *}$

BLOOD UREA NITROGEN (mg\%)

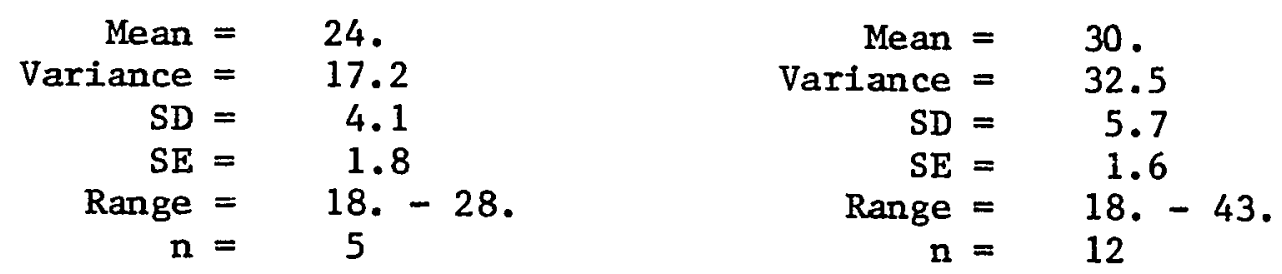

CHLORIDES (meq/1)

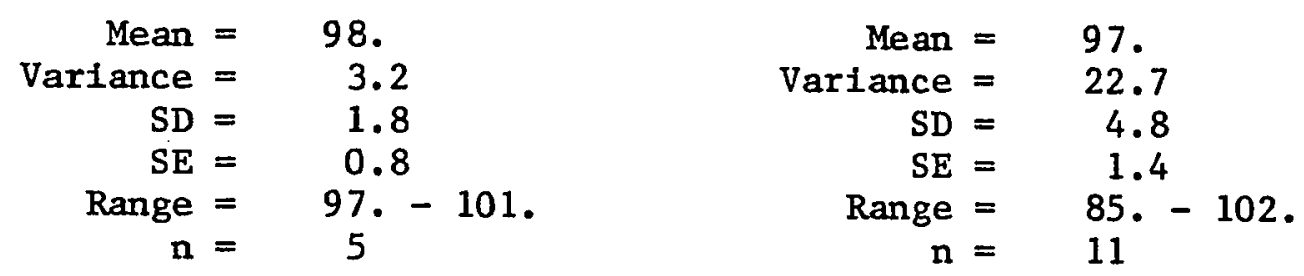

CHOLESTEROL (mg\%)

$\begin{aligned} \text { Mean } & =94 \\ \operatorname{Variance} & =656.3 \\ \mathrm{SD} & =25.6 \\ \mathrm{SE} & =11.5 \\ \text { Range } & =51 .-115 \\ \mathrm{n} & =5\end{aligned}$

GLUCOSE (mg\%)
Mean $=58$.
Variance $=340.4$
$\mathrm{SD}=18.4$
$S E=5.3$
Kange $=25 .-100$,
$\mathrm{n}=12$

$$
\begin{array}{rrr}
\text { Mean } & = & 150 . \\
\text { Variance } & = & 1,300.0 \\
\mathrm{SD} & = & 36.1 \\
\mathrm{SE} & = & 16.1 \\
\text { Range } & = & 115 .-200 \\
\mathrm{n} & = & 5
\end{array}
$$

$$
\begin{aligned}
& \text { Mean }=143 \text {. } \\
& \text { Variance }=5,475.4 \\
& \mathrm{SD}=74.0 \\
& \mathrm{SE}=21.4 \\
& \text { Range }=45 .-299 \text {. } \\
& \mathrm{n}=12
\end{aligned}
$$

* Young elk are less than two years of age

$\dot{*} \dot{*}$ Oild eijk are two years of age and older 
TABLE XXVII

SUMMARY OF VALUES FOR SERUM METABOLIC BY-PRODUCTS

FOR TWO AGE GROUPS OF CAPTIVE ELK

Young*

$\underline{01 d * *}$

DIRECT BILIRUBIN (mg\%)

\begin{tabular}{|c|c|c|c|}
\hline Mean $=$ & 0.2 & Mean = & 0.1 \\
\hline Variance $=$ & 0.002 & Varlance $=$ & 0.004 \\
\hline$S D=$ & 0.049 & $S D=$ & 0.064 \\
\hline $\mathrm{SE}=$ & 0.024 & $S E=$ & 0.022 \\
\hline $\begin{array}{r}\text { Range }= \\
\mathbf{n}=\end{array}$ & $\frac{0.1}{4}-0.2$ & $\begin{array}{r}\text { Range }= \\
n=\end{array}$ & $\begin{array}{l}0.0-0.2 \\
8\end{array}$ \\
\hline
\end{tabular}

TOTAL BILIRUBIN (mg\%)

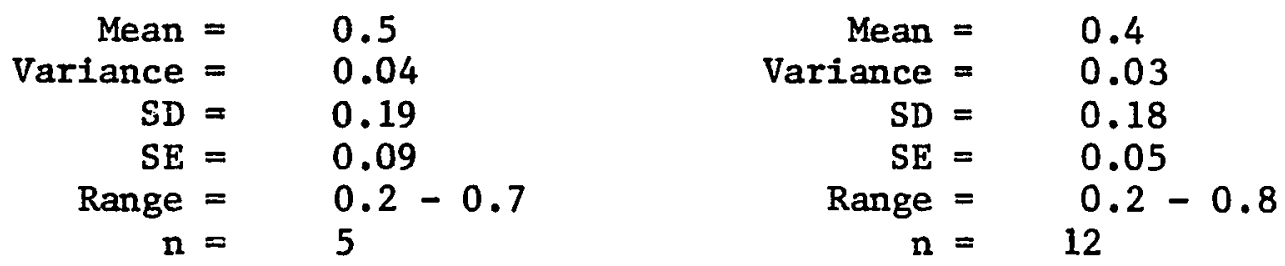

CREATININE（mg\%）

\begin{tabular}{|c|c|c|c|}
\hline Mean $=$ & 1.4 & Mean $=$ & 1.7 \\
\hline Variance $=$ & 0.06 & Variance $=$ & 0.35 \\
\hline $\mathrm{SD}=$ & 0.24 & $\mathrm{SD}=$ & 0.59 \\
\hline $\mathrm{SE}=$ & 0.11 & $\mathrm{SE}=$ & 0.18 \\
\hline $\begin{aligned} \text { Range } & = \\
\mathbf{n} & =\end{aligned}$ & $\begin{array}{l}1.1-1.7 \\
5\end{array}$ & $\begin{array}{r}\text { Range }= \\
n=\end{array}$ & $\begin{array}{l}0.6-2.9 \\
11\end{array}$ \\
\hline
\end{tabular}

URIC ACID (mg\%)

$\begin{aligned} \text { Mean }= & 0.2 \\ \text { Variance }= & 0.01 \\ \mathrm{SD}= & 0.10 \\ \mathrm{SE}= & 0.04 \\ \text { Range }= & 0.1-0.3 \\ \mathrm{n}= & 5\end{aligned}$

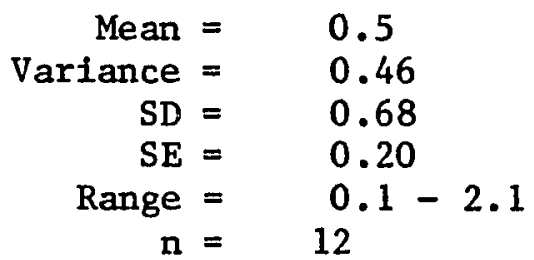

* Young are elk less than two years of age

** old are ellk two years of age and older 
TABLE XXVIII

SUMMARY OF LEVELS OF SERUM ENZYME ACTIVITY

FOR TWO AGE GROUPS OF CAPTIVE ELK

Young*

$01 \mathrm{~d} * *$

ALKALINE PHOSPHATASE (mU./ml $)^{1}$

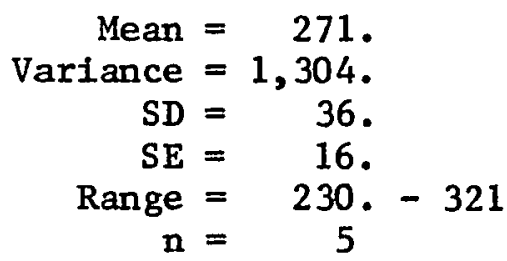

Mean $=128$.

Variance $=8,346$.

$\mathrm{SD}=91$.

$\mathrm{SE}=26$.

LACTIC DEHYDROGENASE (mU./ml) ${ }^{1}$

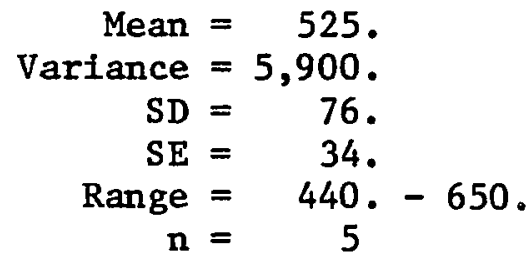

Mean $=453$.

Variance $=12,392$.

$\mathrm{SD}=111$.

$\mathrm{SE}=32$.

Range $=325 .-680$

$\mathbf{n}=12$

GLUTAMIC OXALACETIC TRANSAMINASE (mU./m1 $)^{1}$

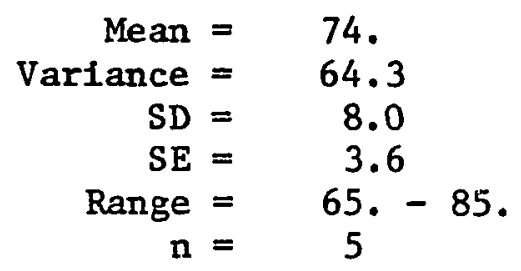

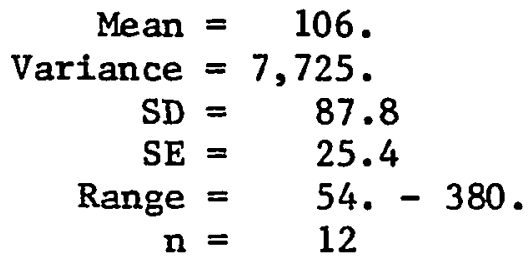

* Young are elk less than two years of age

** 0ld are elk two years of age and older

1 International Units, measured at $340 \mathrm{~nm}$ wave length 
TABLE XXIX

SUMMARY OF SERUM MINERAI VALUES FOR

TWO AGE GROUPS OF FREE-LIVING ELK

Young*

$\underline{01 d * *}$

SODIUM (meq/1)

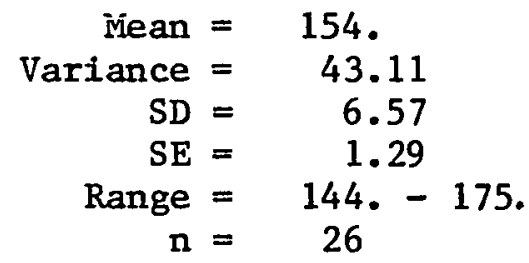

POTASSIUM (meq/1)

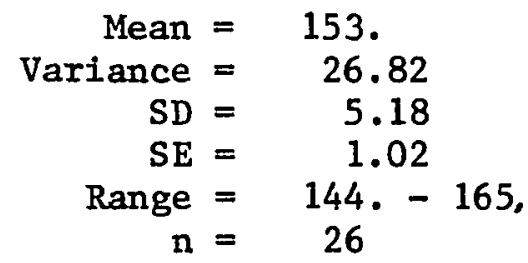

$\mathrm{n}=26$

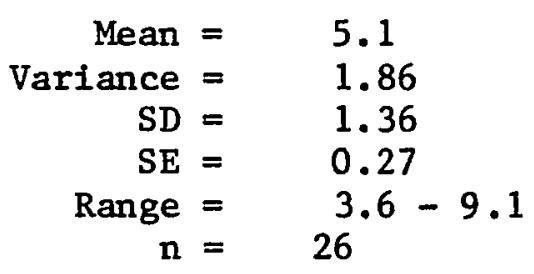

SODIUM/POTASSIUM RATIO

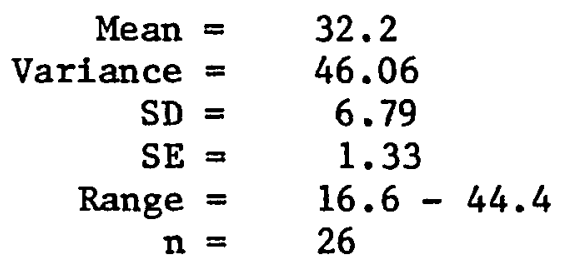

$\mathrm{n}=26$

$$
\begin{aligned}
& \text { Mean }=\quad 34.1 \\
& \text { Variance }=54.78 \\
& \mathrm{SD}=7.40 \\
& \mathrm{SE}=1.45 \\
& \text { Range }=21.4-49.0 \\
& \mathrm{n}=26
\end{aligned}
$$

* Young are elk less than two years of age

** 01d are elk two years of age and older 
TABLE XXX

SUMMARY OF SERUM MINERAL VALUES FOR

TWO AGE GROUPS OF FREE-LIVING ELK

Young*

$\underline{01 d * *}$

CALCIUM (mg\%)

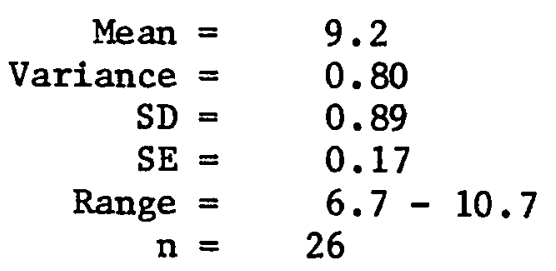

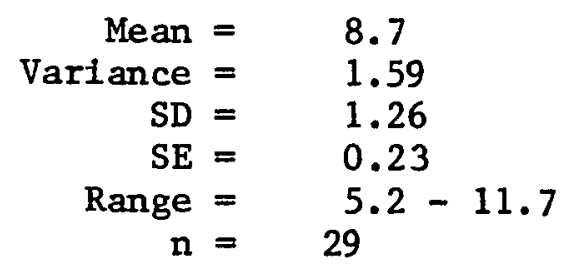

INORGANIC PHOSPHORUS (mg\%P)

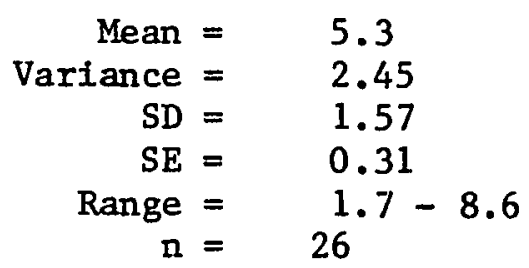

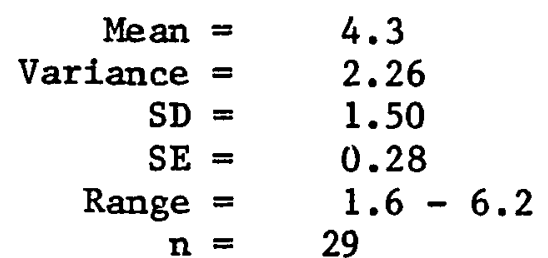

CALCIUM/PHOSPHORUS RATIO

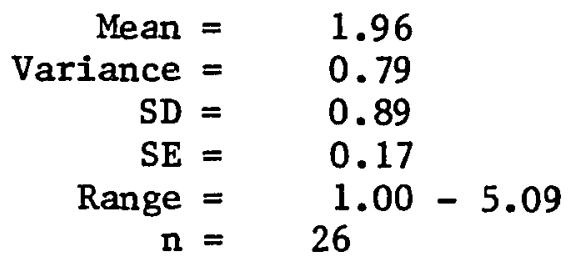

$\mathbf{n}=$

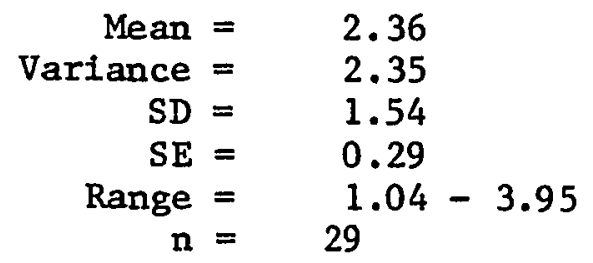

* Young are elk less than two years of age

** Old are elk two years of age and older 
TABLE XXXI

\section{SUMMARY OF VALUES FOR SERUM COMPONENTS}

FOR TWO AGE GROUPS OF FREE-LIVING ELK

Young*

\section{$\underline{01 d * *}$}

BLOOD UREA NITROGEN (mg\%)

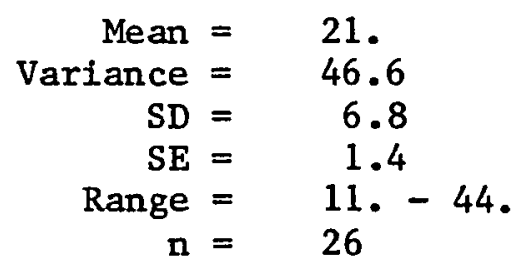

Mean $=24$.

Variance $=30.2$

$\mathrm{SD}=\quad 5.5$

$\mathrm{SE}=1.0$

Range $=17 .-37$.

$\mathrm{n}=29$

CHLORIDES (meq/1)

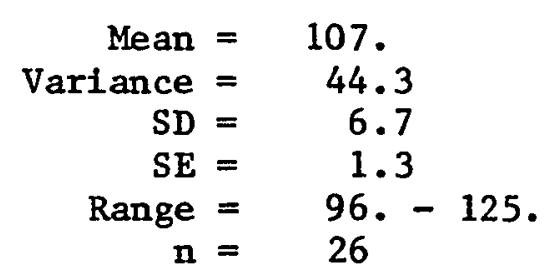

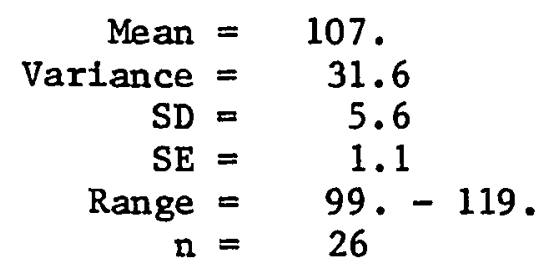

CHOLESTEROL (mg\%)

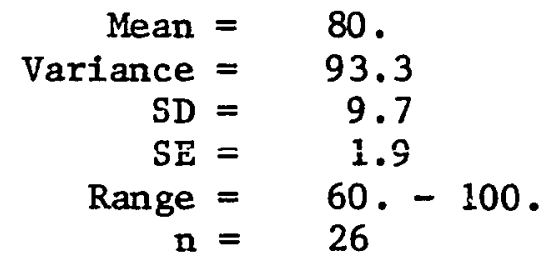

GLUCOSE（mg\%）

$$
\begin{aligned}
& \text { Mean }=87 . \\
& \text { Varlance }=245.7 \\
& \mathrm{SD}=15.7 \\
& \mathrm{SE}=2.9 \\
& \text { Range }=60 .-125 \text {. } \\
& \mathrm{n}=29
\end{aligned}
$$

$$
\begin{aligned}
\text { Mean } & =214 . \\
\text { Variance } & =8,524.7 \\
\mathrm{SD} & =92.3 \\
\mathrm{SE} & =18.1 \\
\text { Range } & =15.0-450.0 \\
\mathrm{n} & =26
\end{aligned}
$$

Mean $=200$.

Variance $=4,375.3$

$\mathrm{SD}=66.1$

$\mathrm{SE}=13.0$

Range $=65.0-399.0$

$\mathrm{n}=26$

* Young are elk less than two years of age

** Old are elk two years of age and older 
TABLE XXXII

SUMMARY OF VALUES FOR SERUM METABOLIC BY-PRODUCTS FOR TWO AGE GRAOUPS OF FREE-LIVING ELK

$\underline{\text { Young* }}$

$\underline{01 d * *}$

DIRECT BILIRUBIN (mg\%)

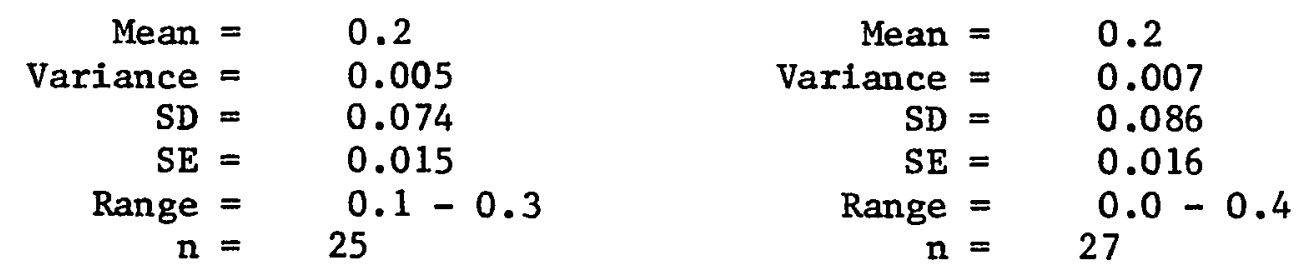

TOTAL BILIRUBIN (mg\%)

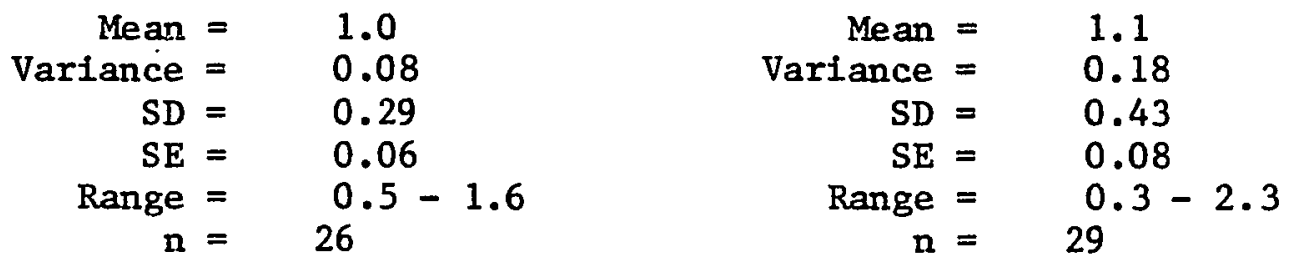

CREATININE (mg\%)

\begin{tabular}{|c|c|}
\hline Mean $=$ & 1.5 \\
\hline Variance $=$ & 0.12 \\
\hline $\mathrm{SD}=$ & 0.34 \\
\hline $\mathrm{SE}=$ & 0.07 \\
\hline $\begin{array}{r}\text { Range }= \\
\mathrm{n}=\end{array}$ & 26 \\
\hline
\end{tabular}

Mean $=\quad 1.6$

Variance $=0.08$

$\mathrm{SD}=0.29$

$\mathrm{SE}=0.06$

Range $=1.1-2.4$

$\mathrm{n}=52$

URIC ACID (mg\%)

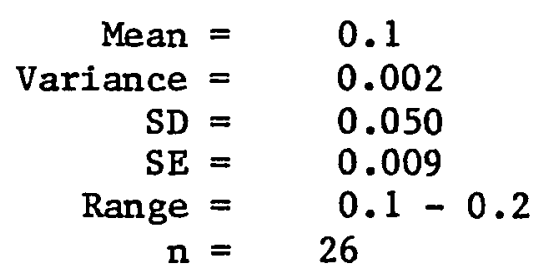

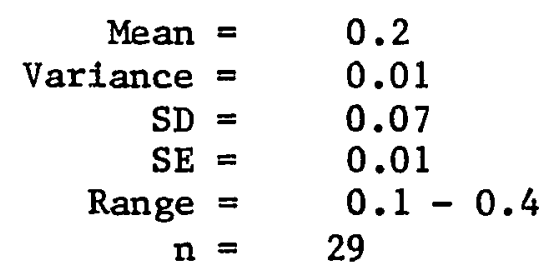

* Young are elk less than two years of age

** 01d are a1k two years of age and older 
TABLE XXXIII

\section{SUMMARY OF LEVELS OF SERUM ENZYME ACTIVITY} FOR TWO ACE GROUPS OF FREE-LIVING ELK

\section{Young*}

\section{$\underline{01 d * *}$}

\section{ALKALINE PHOSPHATASE (mU./ml) 1}

$$
\begin{array}{rlrl}
\text { Mean } & = & 364 . \\
\text { Variance } & = & 12,706 . \\
\mathrm{SD} & = & 112 . \\
\mathrm{SE} & = & 22 . \\
\text { Range } & = & 90 . & -510 . \\
\mathrm{n} & = & 26
\end{array}
$$

Mean $=182$.

Variance $=14,673$.

$\mathrm{SD}=121$.

$S E=22$.

Range $=20 .-650$.

$\mathrm{n}=29$

LACTIC DEHYDROGENASE (mU./ml) $)^{1}$
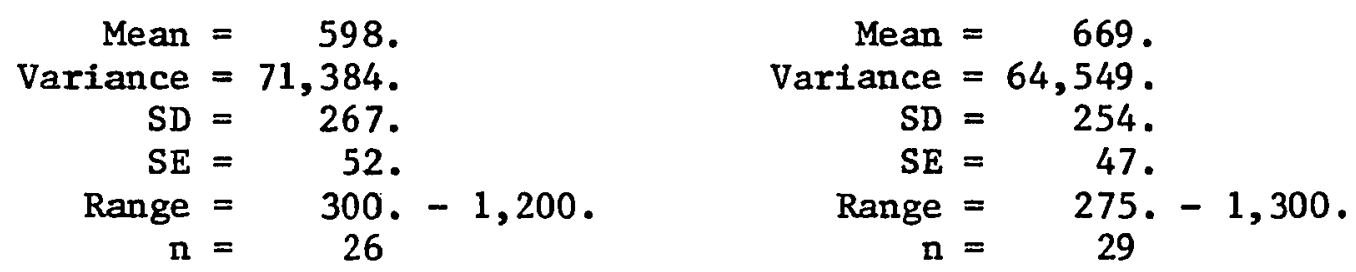

GLUTAMIC OXALACETIC TRANSAMINASE $(\mathrm{mU} . / \mathrm{ml})^{1}$

$$
\begin{array}{rlrl}
\text { Mean } & = & 137 . \\
\text { Variance } & = & 4,783 . \\
\mathrm{SD} & = & 69 . \\
\mathrm{SE}= & 14 . \\
\text { Range }= & 77 .-380 . \\
\mathrm{n}= & 26
\end{array}
$$

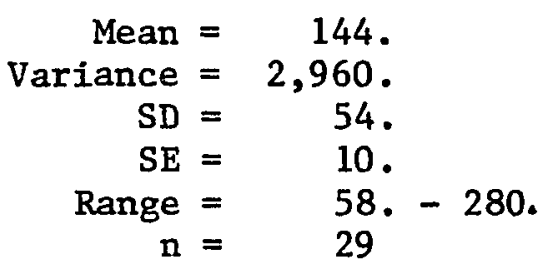

* Young are elk less than two years of age

** Old are elk two years of age and older

1 Inčernationai ünitis, measured at $340 \mathrm{~nm}$ wave Iengtin 
living elk (Tables XXIX through XXXIII). Young elk, both captive and free-living, had higher serum values for sodium, calcium, inorganic phosphorus, glucose and alkaline phosphatase than did the older age group. Mature elk, both captive and free-living, had high serum values for calcium/phosphorus ratio, BUN, creatinine, uric acid and SGOT than did those under two years of age.

Mean values for the seventeen parameters being examined are contained in Table XXXIV for six categories of elk -- dead, living, captive young, captive old, free-living young, and free-living old. Captive elk of mixed ages had higher mean levels of serum potassium, calcium, inorganic phosphorus, BUN, and uric acid. Free-living elk of mixed ages had higher values for sodium, sodium/potassium ratio, calcium/ phosphorus ratio, chlorides, glucose, total bilirubin, alkaline phosphatase, LDH, and SGOT.

A mean inorganic phosphorus level of $7.8 \pm \mathrm{SD}$ of $1.59 \mathrm{mg} \% \mathrm{P}$ was found for captive adult elk, and a level of $4.3 \pm \mathrm{SD}$ of $1.50 \mathrm{mg} \%$ for free-living adult elk. A mean BUN level of $30 . \pm S D$ of $5.5 \mathrm{mg} \%$ was found for captive adult elk, and a level of 24 . \pm SD of $5.7 \mathrm{mg} \%$ for free-living adult elk.

DISCUSSION

The sodium levels I obtained (151. I SD of $6.9 \mathrm{meq} / 1$ ) are comparable to the values of Herin (1968) for 36 Rocky Mountain elk. He reported a mean of 148.2 , SD of 8.62 , SE of 1.436 , and $95 \%$ confidence interval of 145.3 to $151.1 \mathrm{meq} / 1$. The $95 \%$ confidence interval for the elk of my study included a range of 149.7 to $152.9 \mathrm{meq} / 1$. Sodium deficiency 
TABLE XXXIV

MEAN VALUES FOR SERUM CHEMTCALS FOR SIX CATEGORIES OF BLR

\section{DEAD LIVING CAPTIVE YOUNG CAPTIVE OLD FREE-LIVING YOUNG FREE-LIVING OLD}

\begin{tabular}{|c|c|c|c|c|}
\hline Sod1um (meq/1) & 139. & 151. & 144. & 143. \\
\hline Potassium (meq/1) & 11.4 & 5.2 & 5.8 & \\
\hline $\mathrm{Na} / \mathbb{R}^{1}$ Rat10 & 12.2 & 30.6 & 25.1 & 26 \\
\hline Calctum (mg $x$ ) & 7.7 & 9.2 & 10.7 & 10 \\
\hline Phosphorus (mgxP) & 8.0 & 5.5 & 3.3 & \\
\hline $\mathrm{Ca} / \mathrm{P}$ Rat1o & 0.96 & 1.97 & 3.29 & \\
\hline$B U N^{2}$ (mg & 5. & 24. & 24. & 30 . \\
\hline Chlorldes (meq/1) & 99. & 105. & 98. & 97 \\
\hline Cholesterol (mgl) & 81. & 80. & 94. & 58. \\
\hline Glucose (mg $x$ ) & 15. & 192. & 150. & 143. \\
\hline D1rect B1lirubin (mgx) & 0.0 & 0.2 & 0.2 & \\
\hline Total B1lirubin (mgx) & 0.2 & 0.9 & 0.5 & \\
\hline Creatinine (mg/) & 2.0 & 1.5 & 1.4 & \\
\hline Urtc Actd (mgx) & 1.0 & 0.2 & 0.2 & \\
\hline Alkaline Phos. 3 (mل./ml) & 98. & 245. & 271 & 128. \\
\hline $20 H^{4}(\mathrm{mU} / \mathrm{ml})$ & 218 & 598. & 525 & 453. \\
\hline $\mathrm{scot} T^{4}(\mathrm{mU} . / \mathrm{ml})$ & 10. & 130. & 74. & 106. \\
\hline
\end{tabular}

154.

5.1

32.3

9.2

5.3

1.96

21.

107.

80.

214.

0.2

1.0

1.5

0.1

364.

598.

137.

3Alkaline Phoophatase

${ }^{4}$ Serm Glutanlc Oxalacetic Transantrase
153.

4.7

34.1

8.7

4.3

2.36

24.

107.

87.

200.

0.2

1.1

1.6

0.2

182.

669.

144.

$2_{\text {Blood Urea N1trogen }}$ 
can be a problem in domestic ruminants; the likelihood is recognized and $\mathrm{NaCl}$ is usually made available to livestock. Its importance in wild species is not known at this time (Church et al. 1972:44).

The data Herin reported for potassium in 34 elk centered about a mean of $5.48, \mathrm{SD}$ of $0.646, \mathrm{SE}$ of 0.110 , and $95 \%$ confidence interval of 5.26 to $5.70 \mathrm{meq} / 1$. The $95 \%$ confidence interval for the elk of my study includes a range of 4.9 to $5.5 \mathrm{meq} / 1$. With rare exceptions, potassium deficiency is not believed to be a problem in ruminants since the content of this element in most forages is greater than $1 \%$ of the dry matter (Church et al. 1971:455). At the other extreme, ruminants may ingest large quantities of potassium without apparent detrimental effects, as occurs during consumption of lush grass and alfalfa hay (Church et a1. 1971:458).

For normal function in human patients it is imperative that Na:K ratio be maintained within a very narrow range of variability. In medical practice, if any pathological condition causes the plasma Na: $\mathrm{K}$ ratio to decrease from the usual $145.5 / 5=30$ to $130 / 6=22$, immediate intravenous infusion of solutions of sodium salts is necessary. My data indicate that normal physiological mechanisms involving kidney function and water balance regulate the proportions of sodium and potassium at the same serum ratios in $e 1 k$ as in humans.

Serum calcium levels for elk are also reported in the literature. Herin (1968) found a mean of 9.4 , SD of $0.44, \mathrm{SE}$ of 0.07 , and $95 \%$ confidence interval of 9.26 to $9.54 \mathrm{mg} \%$. The $95 \%$ confidence interval for the elk of my study includes a range of 8.9 to $9.5 \mathrm{mg} \%$. Greer and Picton (1964) investigated $\mathrm{Ca}^{++}$concentration in serum from three 
different elk herds. They reported a mean of 13.5 and range of 8.7 to $29.0 \mathrm{mg} \%$ for the Sun River herd, a mean of 9.9 and range of 6.5 to 12.2 $\mathrm{mg} \%$ for the Yellowstone herd, and a mean of 11.0 and range of 8.2 to $18.4 \mathrm{mg} \%$ for the Gallatin herd.

Serum calcium concentration was one of the eight blood parameters used by Blunt (1959) in comparing three different elk diets. He found, as did Wise et al. (1963) In their study of calves, that the Ca: $\mathrm{P}$ ratios rather than calcium levels in the diet influence serum levels of this element. Petrusewitz (1967:229) believes that the pecullarities of the chemical composition of plants, especially the predominance of carbohydrates such as lactose, arabinose, and galactose, increases or reduces the assimilibility of calcium by animals.

In cattle, $50 \%$ to $70 \%$ of the serum calcium is in ionic form and the remainder is bound to serum proteins, particularly albumin and gamma globulin, and is non-diffusible. The ionic and bound forms exist in dynamic equilibrium and redistribution between the two is a relatively rapid process (Church et al. 1971:418). The level of serum calcium is a reflection of that which enters and leaves the circulatory system, which in turn represents a balance between absorption, withdrawal or deposition in bone and antlers, and excretion via urine or feces.

Greer and Picton (1964) examined serum levels of inorganic phosphorus in elk, reporting a mean of 3.6 and range of 1.7 to $5.1 \mathrm{mg} \%$ for the Sun River herd, a mean of 5.4 and range of 2.5 to $7.6 \mathrm{mg} \%$ for the Yellowstone herd, and a mean of 6.6 and range of 3.2 to $12.2 \mathrm{mg} \%$ for the Gallatin herd. In calves, Wise et al. (1963) found that an elevation of dietary phosphorus caused a linear decrease iñ seruili calcium. ivumerous 
experiments involving domestic ruminants have demonstrated that calcium utilization is affected by the amount of phosphorus in the diet (Church et al. 1971:421).

The response of serum phosphorus to dietary increases of this element is rapid and directly related to the amount in the feed given to calves (Wise et al. 1958). The findings of these authors indicate the significant impact of this element upon forage utilization in the growing ruminant. Calves fed at the $0.14 \%$ level of dietary phosphorus required 6.6 pounds of feed for each pound of body weight gained. Calves fed at the $0.22,0.30$, or $0.38 \%$ levels of dietary phosphorus needed only 4.9 pounds of feed for each pound of body weight gained.

Caution should be exercised regarding the application of techniques and practices developed for the nutrition of domestic ruminants to wild animals, either in captivity or free-living. In contrast to management for increased growth rate as measured by weight and size, studies described by Maynard and Loos11 (1969:448) demonstrate that restricted food Intake resulted in leaner animals with less skeletal size, but improved health, longevity, and female fertility. Restricted food Intake also delayed the onset of degenerative disease. A dietary Ca:P ratio lower than $1: 1$ is deleterious to the ruminant animal which can tolerate ratios of $\mathrm{Ca}: \mathrm{P}$ as high as $7: 1$ without adverse effects. This is in marked contrast to the non-ruminant for which ratios greater than 3:1 are detrimental, but which can function satisfactorily with ratios of less than $1: 1$. In their examination of this ratio in Rocky Mountain elk, Greer and Picton (1964) reported values of 3.9:1 for the Sun River herd, 1.8:1 for the Yellowstone herd, and 1.8:1 for the 
Gallatin herd.

It is believed that a disturbance of the optimum correlation of phosphorus and calcium in the grass and twigs of grown trees will force members of the deer family to switch over to feeding on young trees and shrubs (Petrusewicz 1967:229). Among free-living elk, a dietary Ca:P ratio lower than unity is a situation that would rarely occur. On the contrary, it is speculated by Wise et a1. (1963:83) that the ruminant has subsisted and developed on forages which normally have a high Ca:P ratio, and has more highly developed physiological mechanisms than the non-ruminant for handling high levels of calcium.

The one other investigator (McBee 1964) to report on BUN levels in elk serum listed nine values ranging from 3.0 to $42.0 \mathrm{mg} \%$, a far wider range than was found in this study or during the investigation of Weber and Bliss (1972).

Some investigators report values for non-protein nitrogen (NPN) of the blood. This fraction includes BUN, amino acids, uric acid, creatine, creatinine, and "undetermined nitrogen". Variations in the blood level of NPN normally reflect fluctuations in the BUN concentration because BUN contributes from 35 to $45 \%$ of the total NPN (Bandy et a1. 1957).

The value of the BUN measurement lies in its potential for assessing the protein intake and utilization by the ruminant (Preston et al. 1965). Based on his work with bighorn sheep, Franzmann (1972) expressed the view that low BUN at capture may reflect low protein content of the winter range forage and be a useful criterion for evaluating forage in other free-ranging animals. He proposed for bighorn sheep the standard 
that serum BUN values above $20 \mathrm{mg} / 100 \mathrm{ml}$ indicate adequate protein intake, between 15 and $20 \mathrm{mg} / 100 \mathrm{ml}$ indicate a potential intake problem, and below $15 \mathrm{mg} / 100 \mathrm{ml}$ indicate a low protein intake.

For moose, however, Houston (1969) reported BUN values during July to September averaged $12.9 \pm 3.0 \mathrm{mg} \%$, significantly higher than $5.1 \pm$ $1.8 \mathrm{mg} \%$ recorded between October and February, and believed the higher values reflected a high plane of nutrition and positive nitrogen balance during the summer, compared with lower levels during the winter period.

In their study of Roosevelt elk, Weber and Bliss (1972) found that blood urea nitrogen in free-living elk ranged from 13.8 to 37.0 $\mathrm{mg} \%$ and in zoo elk from 16.2 to $22.9 \mathrm{mg} \%$. The narrower range of variability in zoo elk may be related to the more uniform diet which the captive elk recelved. Weber and Bliss (1972) also found a difference in BUN levels between mature elk and calves. Blood urea content is belleved to vary directly with the protein content of the diet (Franzmann and Thorne 1970). Within the experimental limitations discussed by Eggum (1970) it appears that BUN determinations could be of value in evaluating quality of forage.

Comparable data for chlorides are not available for elk from other investigators. Normal serum values in domestic ruminants average 103 meq/1; a high concentration of chloride is also found in ruminant saliva, on the order of $100 \mathrm{meq} / 1$ (Church et al. 1971:459).

Chloride is found in large concentrations both within and without the cells of the body tissues. Blood cells contain about one-half as much as serum. The chlorides of the blood make up two-thirds of its anions, an indication of their role, with bicarbonate lons, in regulation 
of osmotic pressure. Deficiency symptoms that can be attributed to chloride alone have not been described in ruminants, due to the fact that most forage contains appreciable amounts (Church et al. 1971). The practice of putting out blocks of sodium chloride for use by elk is believed to lack merit from a nutritional viewpoint (Murie 1951b:312). Cholesterol is a lipid component of the serum which is synthesized in the liver from acetate, and is not a dietary essential. Cholesterol has not been found in plants (Dukes 1947:351). McBee (1964) reported serum cholesterol values for six elk which ranged from 64.3 to $111.5 \mathrm{mg} \%$ which is within the wider range of 25 . to 125 . $\mathrm{mg} \%$ which I found.

In their study of thyroid activity in white-tailed deer, Seal et al. (1972b) referred to cholesterol as a measure of fat metabolism, and reported values ranging from $49 \pm 8.0$ to $69 \pm 6.9 \mathrm{mg} \%$ for wild and captive deer during varying seasons and diets.

The usual normal range given for cattle is 50 to $230 \mathrm{mg} \%$ (Dukes 1947:54). The mean concentrations of cholesterol reported by Tumbleson and Hutcheson (1971) for 510 female dairy cattle were often over twice as high as the $80 . \pm 18.4 \mathrm{mg} \%$ which I found for elk. Colby et al. (1950) found concentrations of $195 \pm 23.4 \mathrm{mg} \%$ in growing beef calves, and established a significant coefficlent between serum cholesterol levels and rate of weight gain. This data indicates a relationship may exist between high levels of cholesterol and the incidence of spontaneous atherosclerosis in cattle (Tumbleson and Hutcheson 1971) to which elk with much lower cholesterol levels may not be subject.

The high variance for serum glucose $(6,481 \mathrm{mg} \%$ ) 1llustrates the 
fact that the level of this component has a wide normal range in elk, as it does in most animals (Blunt 1959). McBee (1964) listed serum glucose values for eleven elk that ranged from 52.3 to $265 \mathrm{mg} \%$, which is well within the wider range of 15 to $450 \mathrm{mg} \%$ which I found.

The blood sugar of adult ruminants is almost exclusively glucose (Whitehead 1962), originating, primarily, from three sources. The first, intestinal absorption, is related to the amount and kind of carbohydrates in the forage. For a ruminant animal, in which digestion is slow and more or less continuous, the rate of absorption of monosaccharides from the digestive tract probably does not vary sufficiently to produce a marked fluctuation in the serum glucose level from that source. The second, glucose arising from the hydrolysis of glycogen, is largely under the control the nervous system. Through the action of the adrenal glands, the rate of conversion is sharply increased in an excited animal, producing a pronounced and rapid rise in serum glucose levels. The third source, synthesis of glucose from other compounds such as amino acids or propionate, is controlled by the processes of metabolism which probably produce little fluctuation in serum glucose levels under ordinary circumstances (Hodgson et al. 1932).

Urinalyses were done on samples obtained from seven free-living elk. Two elk with serum glucose levels above $300 \mathrm{mg} \%$ had high urine glucose levels. By contrast, elk with serum glucose in the 119 to 189 mg\% range were negative for urine glucose. This finding may indicate the range in which the renal threshhold lies for blood glucose in elk. Bllirubin is a red bile pigment formed from hemoglobin during destruction of erythrocytes by the reticuloendothelial system. Deter- 
mination of the quantity of bilirubin in the serum, where it is normally present in relatively small amounts, reveals two fractions which are direct-reacting (conjugated) and indirect-reacting (nonconjugated) bilirubin. No other values for bilirubin are available from elk for comparative purposes.

The direct-reacting form of bilirubin is the water-soluble bilirubin diglucuronide which has been processed by the liver and should be excreted in the bile. The presence of direct bilirubin above normal amounts in the blood is an undesirable condition (Davidsohn and Wells 1962).

For dairy cattle, Mylrea and Healy (1968) found an over-all mean of $0.22 \pm \mathrm{SD}$ of $0.10 \mathrm{mg}$. Tumbles on et al. (1970b) while studying the blood chemistry of adult barbary sheep (Ammotragus lervia) In captivity, found a total bilirubin level of $0.3 \pm$ SD of $0.1 \mathrm{mg}$, with a range of 0.2 to $0.5 \mathrm{mg} \%$. This serum determination is very sensitive to hemolysis which can cause inaccurately high readings. The normal bilirubin component of the blood is in a water-soluble form, loosely complexed with serum proteins, which is in the process of being carried from the cells of the reticuloendothelial system to the liver, and present in low concentrations.

No other data for creatinine values in elk are available for comparative purposes. Colby et a1. (1950) reported a mean level of 1.32 $\pm \mathrm{SD}$ of $0.016 \mathrm{mg} \%$ for growing beef calves, and Mylrea and Healy (1968) found a mean level of $0.04 \pm .25 \mathrm{mg} \%$ for healthy dalry cattle. This substance, which arises from the catabolism of creatine in muscle action, is primarily present in the urine. Excessively high levels 
could be evidence of impaired renal function as occurs with leptospirosis, to which elk are subject. Captive white-tailed fawns were found to have a mean value of $2.5 \pm \mathrm{SD}$ of $0.3 \mathrm{mg} \%$ for creatinine by Tumbleson et al. (1970a).

Uric acid is another of the serum constituents for which no data are available for elk. LeResche and Davis (1971) reported values from moose during winter or $0.25 \pm 0.15 \mathrm{mg} \%$ which they felt were unexplainably low. Teeri et al. (1958) reported data from white-tailed deer during February and March, periods of poor nutrition, with fifteen determinations ranging from 0.7 to $1.8 \mathrm{mg} \%$ which varied little and showed little correlation with the condition of animals. It is expected that levels of serum uric actd would rise with malnutrition due to the increased deamination of protein (LeResche and Davis 1971). Tumbleson (1969) reported the levels of uric acid in ovine, porcine and bovine sera were within the range of 0.05 to $1.00 \mathrm{mg} \%$.

As is true of the other two enzymes, the variance for alkaline phosphatase is large. Wise et al. (1963) found in their study of Hereford calves that activity of alkaline phosphatase was inversely related to serum inorganic phosphorus levels.

Mylrea and Healy (1968) found that the most striking feature about alkaline phosphatase results in their study of dairy cattle was the large variation between animals within herds and within classes. They reported that other investigators, as well, found considerable differences between breeds and individual animals and were unable to explain the large variations. In the serum of bulls, Roussel and Stallcup (1966) found far higher alkaline phosphatase activity during 
summer as compared with winter values.

In Roosevelt elk, alkaline phosphatase showed no significant difference between free-living and captive animals, but Weber and Bliss (1972) found a clear decrease in concentration with increasing age. In cervid physiology, significant correlations have been made between alkaline phosphatase and antler growth. Graham et al. (1962) and Kuhlman et al. (1963) found elevations of circulating alkaline phosphatase to more than three times the resting levels during the periods of antler growth in male white-talled deer. Does did not exhibit the same annual cyclic peaks of enzyme activity.

Lactic dehydrogenase (IDH) has been studied in white-talled deer by Seal et al. (1972) who found profound delayed effects of restraint and drugs reflected in the magnitude of the increased levels of enzyme activity after handling. In the opinion of Prasse (1969), it is established that LDH activity in bovine serum is considerably higher than that found in most animal species, with sheep and goats giving values which can approach those of cattle but are not normally as high. Weber and Bliss (1972) found the $\mathrm{LDH}$ values in elk were quite variable and showed no correlation with age or captivity.

The serum glutamic oxalacetic transaminase level is an important parameter in ruminants because of the relationship between elevated SGOT activity and the form of myopathy known as white muscle disease which is related to selentum deficiency in forage (Whanger et al. 1969). An elk cow at the Portland Zoological Gardens, 2-11 (Figure 6), yielded high readings for $S G O T$ and exhibited severe stiffness in the hindquarters during two years of observation. After she was moved to the Jewell 
Wildlife Meadows, she was immobilized and biopsies were taken from both the right and left semitendinosus muscles. Examination of the slides prepared from these Eissues by the Veterinary Diagnostic Laboratory at Oregon State University falled to disclose the characteristics of white muscle disease. Increased SGOT is seen in other forms of cell necrosis and tissue damage (B1inko and Dye 1958) which could be related to the posterior paresis displayed by this elk cow.

Weber and Bliss (1972) found that SGOT in elk increased with maturation and body size. Additional tests, particularly on young elk, are necessary to verify this trend.

Seal et al. (1972a) found a 38-fold increase in SCOT activity as an afiermath of restraint and handling in white-tailed deer, and offered the suggestion that the final determination of baseline values in deer will perhaps require telemetry, using sensors not yet available, or the use of attached blood-drawing devices of the type recently designed for sheep.

For several of the serum parameters, little difference associated with age was found, which may reflect the premise that functional development of the rumen is accompanied by physiological changes that make the young ruminant animal, nutritionally speaking, very like the adult (McCandless and Dye 1950).

Both Braun (1946) and Mylrea and Bayfield (1968) found that serum levels of inorganic phosphorus went down with age in cattle under controlled diet and environmental conditions. I found this to be true for elk, as well.

In their study of Roosevelt elk, Weber and Bliss (1972) found no 
significant difference in serum glucose levels between mature and immature animals.

Glucose is the principal blood precursor of lactose (Maynard and Loosli 1969). To assess the effect that substantial amounts of glucose being removed from the blood to meet the needs of the nursing calf might have on serum glucose levels of the mother, this parameter was examined for lactating females and non-lactating females (Table XXIII). My finding of a mean glucose only slightly lower for the lactating elk is similar to that reported for dairy cattle (Hodgson et al. 1932), and supports the view that compensatory mechanisms are functioning to overcome the effect of glucose removal from the bloodstream.

A team of investigators at the Sinclair Research Farm, University of Missouri, which has extensively studied animal blood chemistry and its relationship to the aging processes (Tumbleson et al. 1972a), report higher BUN levels in older animals. They found that mean serum concentrations of BUN increased significantly until two years of age, but did not change thereafter. This is in agreement with my findings for elk.

Serum from the younger elk gave alkaline phosphatase values approximately twice as high as that of the older animals. This finding parallels that of other investigators for white-tailed fawns (Tumbleson et al. 1970a), cows (Braun 1946), and bulls (Roussel and Stallcup 1966). Based on their studies of feed restriction on antler development in white-tailed deer, Long et al. (1959) found that the inorganic phosphorus level of the blood dropped dramatically after ten weeks on half rations; but that five weeks of feed restriction was of too short dura- 
tion to have a discernible effect on inorganic phosphorus levels. This would serve to demonstrate the value of this parameter in discovering the existence of a long-standing nutritional deficiency, as might occur among free-living elk during winter. Male white-tailed deer under three years of age, due to body growth which takes precedence over antler development, require two times the protein intake of older animals, and require over $0.09 \%$ calcium and $0.25 \%$ phosphorus in their diet (Long et a1. 1959).

The higher levels of inorganic phosphorus in captive elk affected the calcium/phosphorus ratios, giving values of $1.32 \pm \mathrm{SD}$ of 0.21 for adult captive elk and $2.36 \pm$ SD of 1.54 for the free-living adults.

Weber and Bliss (1972) found that serum glicose levels were signiflcantly higher in free-living elk than in captive. Greater excitability among the free-1iving animals was probably a factor in this difference (Franzmann 1972).

Included among the free-living elk were some which seemed espectal1y stressed at the time blood was drawn and for which SGOT values exceeded $1100 \mathrm{mU} . / \mathrm{ml}$. The SGOT values are highly variable and other factors influencing this must be considered when evaluating and applying these data.

CONCLUSIONS

The serum chemistry values obtalned for the 72 living elk are presented as encompassing the range that may be considered baseline or . . "normal" for this species.

The variables free-living and captive appear to influence 
physiological values due to the conditions associated with them, such as the stresses arising from excitement, confinement, and the presence of people. Many other variables related to the captive versus free-living comparison, such as quality of protein and mineral intake, and aspects of the wild environment, such as the leaching of nutrients in areas of high rainfall and exposure to disease agents, undoubtedly have an effect. As comparative data on blood physiology from captive and free-living animals accumulate, the impact of these varlables can be separated and accurately evaluated by refined statistical procedures.

The captive female elk of this study exhibited a fairly constant pattern of annual calving. By contrast, declining productivity among some herds of free-living elk is a source of concern to game managers. Data from this study suggest that the diet of some free-living elk in Oregon may be marginal for proteir and phosphorus, as reflected in serum BUN and inorganic phosphorus levels which, in turn, could influence the reproductive success of the free-living elk. 
CHAPTER VII

\section{VIRAL AND BACTERIAL DISEASES}

Wild artiodactyls have been the subjects of intensive investigation as possible hosts or reservoirs of diseases transmissable to man and livestock. Among the earliest diseases to receive attention in this role was brucellosis, a highly contagious infection of many species, including cattle, bison, $e 1 k$ and moose, which is caused by bacteria of the genus Brucella. Brucella infections in ruminants can localize in the pregnant uterus where resulting pathology interferes with fetal circulation, causing abortion (Davis et a1. 1970). The occurrence of bruce1losis in the elk of Yellowstone National Park is of importance to this study because the Wallowa County herds originated from elk transplanted to Oregon from Yellowstone.

Bang's disease, the form of brucellosis caused by Brucella abortus, was reported from bison and elk at Yellowstone by Rush (1932). Tunnicliff and Marsh (1935) studied Bang's disease in Yellowstone ungulates where it was believed to have spread from domestic cattle to bison and, in turn, to elk. A survey by Moore (1947) at Elk Island National Park, Canada, found 186 elk negative for brucellosis, but found positive reactions among 37 bison tested. A survey of 343 bison, 221 elk and 124 moose at E1k Island National Park by Corner and Connell (1958) found 25 positive and four suspicious reactions among the elk, with seven of the elk classified as negative showing agglutination at 
the 1:25 dilution. They expressed the view that elk present a greater problem in both domestic and wildlife brucellosis control than do bison.

Denney (1965a) reported that blood samples from 517 deer, 163 elk, and 40 pronghorn in Colorado were found to be negative for brucellosis and leptospirosis. A popularized discussion of his findings (Denney 1965b) was published with the goal of refuting the allegations of stockmen that big game species serve as reservoir hosts for these diseases.

Leptospirosis is a group of infectious diseases of man and animals caused by serologically distinguishable members of the helicoidal bacterial genus Leptospira (Chandler and Read 1966). Numerous strains exist of the actively motile, monospecific spirochete, Leptospira interrogans (WHO 1967), for which small mammals, especially rodents, are the chief reservoirs. Leptospires colonize in the kidney tubules of the host, are excreted with urine, and thereby contaminate the environment. The maintenance and transmission of this bacterium, which cannot tolerate dryness or heat, are believed to be integrally associated with moist soil and stagnant ponds (Davis et al. 1970).

Strains of the genus Leptospira resist differentiation by cultural or morphological means, but are antigenica11y distinct. Based on serological reactions in the host, over 130 individual serotypes have been identified (Busch 1970). Of these, 23 have been isolated in North America, with more suspected (Davis et a1. 1970). Employing the techniques of histology, serology, and culture, researchers have found evidence of leptospires in many wildlife species 
that are common in Oxiguis, such as bobcats, rabbits, squirrels, rats, mice, voles, muskrats, raccoons, gulls, bats, deer, skunks, foxes, and beavers (Busch 1970, and Roth 1964).

The public health aspects of animal leptospirosis were discussed by Reinhard (1954). In his review of animal reservoirs of leptospires around the world, Babudieri (1958) distinguished between the true carrier and the host which releases this pathogen only temporarily. Hanson (1961) discussed wild animal reservoirs and their importance in epidemiology.

The 19 pathogenic serotypes and subserotypes found in the continental United States are reviewed by Roth (1964) together with the wide variety of hosts for leptospirosis among wildlife species. The need for more information on leptospirosis in wild animals is cited by Busch (1970).

In their authoritative publication, Galton et al. (1962) described the epidemiology, clinical manifestations in man and animals, and methods in laboratory diagnosis of leptospirosis. Reilly et a1. (1962) reported leptospiral serotypes in 23 of 103 animals. McGowan et a1. (1963) isolated the serotype pomona from a deer and fetus, and found significant levels of agglucinins in the serum of moose examined in Canada.

Reilly et al. (1961) found leptospires excreted in the urine of infected white-tailed deer and cattle, and evidence of the transmission of leptospires by intraperitoneal, conjunctival, nasa1 and vaginal routes.

Trainer et al. (1963) assessed the role of deer in the epizooti- 
ology of leptospirosis in Wisconsin and stressed the need for field studies to clarify the significance of infectious diseases in wild populations.

Bluetongue is an infectious, arthropod-borne disease of domestic and wild ruminants characterized by inflammation of the mucous membranes of the mouth, nose and gastrointestinal tract. Just prior to death, excessive salivation commonly occurs, the tongue swells, and the purpleblue discoloration which gave rise to the name develops (Davis et al. 1970). Principally a disease of domestic sheep, in which it was originally described and called catarrhal fever or "soremuzle" (Smith and Jones 1957), this disease is of interest because northeastern Oregon elk share winter range areas with domestic sheep.

Trainer and Jochim (1969) reported on serologic evidence of bluetongue in wild ruminants of North America. Experimental bluetongue disease was described in white-tailed deer by Vosdingh et al. (1968). Bluetongue virus (BTV) was shown by Murray and Trainer (1970) to exist naturally in elk; they suggested this species as a possible reservoir. Their experimental exposure studies demonstrate that elk are susceptible to BTV, although clinical signs can be mild or inapparent. It has been found that following recovery from BTV, deer and sheep are resistant to subsequent infection by the same viral strain (Davis et al. 1970). An examination of 1,012 sera from a variety of wild North America ruminants disclosed a high prevalence of BTV serologic reactors in elk from Idaho (29/54), but none of the sera of elk tested in Wyoming $(0 / 10)$ was positive by the agar gel precipitin (AGP) test (Trainer and Jochim 1969). 
METHODS

The sera from 67 elk were tested for bruceliosis, bluetongue virus and leptospirosis. The animals tested (see Table II) include 38 free-1iving elk from Wallowa County, 11 free-living elk from Umatilla County, nine captive elk from the Woodland Park Zoo, five captive elk from the Tacoma Zoo, and four captive elk from the Portland Zoo.

A11 67 tests for brucellosis, employing the plate agglutination method, were done in 1971 and 1972 under the direction of Dr. Dean Smith, Veterinarian-in-Charge, Veterinary Diagnostic Laboratory, Department of Veterinary Medicine, Oregon State University, Corva11is, Oregon.

Twenty-nine of the 67 tests for leptospirosis were also done in 1971 and 1972 at the Veterinary Diagnostic Laboratory, employing the macroscopic agglutination test to demonstrate reactivity to five leptospiral serogroups. These five serogroups are pomona, icterohaemorrhagiae, canicola, grippotyphosa, and hardjo.

During the latter half of 1972,38 tests for leptospirosis were done at the Bacterial Zoonoses Section, Center for Disease Control, U.S. Public Health Service, Atlanta, Georgia. This laboratory, under the direction of Dr. James W. Glosser, employs the microscopic agglutination test and a battery of 13 serotypes as antigens. These 13 serotypes are ballum, canicola, icterohaemorrhagiae, bataviae, grippotyphosa, pyrogenes, autumnalis, pomona, wolffi, australis, tarassovi, georgia, and fort bragg. The sera from 38 free-1iving elk from Wallowa County were tested. 
Al1 67 tests for bluetongue virus, using the agar gel precipitin method described by Jochim and Chow (1969), were done in 1971 and 1972 at the Veterinary Diagnostic Laboratory, Oregon State University, Corvallis, Oregon.

RESULTS

Sera from all $67 \mathrm{elk}$ tested during this study were negative for bricellosis. Of the 38 free-living elk tested for leptospirosis by the microscopic agglutination test, 16 showed positive reactions to one or more leptospiral serotypes at a significant titer of 1:100 or greater. Another eight elk showed positive reactions at the 1:50 level. Titers and serotypes for all elk exhibiting reactivity are listed in Table $\mathrm{XXXV}$. I believe this to be the first report of serological reactivity to leptospirosis in e1k. Results of the 29 tests for leptospirosis by the macroscopic agglutination method were negative. No positive reactivity to bluetongue virus was found among the 67 serum samples tested.

DISCUSSION

The negative findings for bluetongue and brucellosis among a11 elk examined in my study would indicate that these diseases are not established in Oregon herds and it is not likely that Oregon elk serve as a reservoir for the spread of these diseases to sheep and cattle. The methods of transmission of BTV in wild ruminants are unknown but are expected to be comparable to findings for domestic species in which hematophagous insects serve as biological or mechanical vectors. 
TABLE XXXV

SUMMARY OF ANTIBODY TITERS TO SPECIFIC LEPTOSPIRAL SEROTYPES* AMONG 38 SAMPLES OF ELK SERUM

\begin{tabular}{|c|c|c|c|c|c|c|c|}
\hline $\begin{array}{c}\text { Anima1 } \\
\text { No. } \\
\end{array}$ & ba1lum & $\begin{array}{l}\text { icterohaemor- } \\
\text { rhagaie } \\
\end{array}$ & $\begin{array}{l}\text { grippo } \\
\text { typhosa }\end{array}$ & pyrogenes & autumnalis & australis & fort bragg \\
\hline 1 & $1: 50$ & $1: 100$ & -- & -- & -- & -- & $1: 50$ \\
\hline 2 & $1: 50$ & $1: 50$ & $1: 100$ & -- & -- & -- & $1: 100$ \\
\hline 3 & -- & $1: 50$ & -- & -- & -- & -- & $1: 100$ \\
\hline 4 & $1: 100$ & $1: 50$ & -- & -- & -- & $1: 100$ & -- \\
\hline 5 & $1: 50$ & -- & -- & -- & -- & -- & -- \\
\hline 6 & $1: 100$ & $1: 100$ & -- & -- & -- & -- & $1: 100$ \\
\hline 7 & $1: 50$ & -- & -- & -- & -- & $1: 100$ & -- \\
\hline 8 & -- & $1: 50$ & -- & $1: 100$ & -- & -- & -- \\
\hline 9 & $1: 200$ & -- & -- & -- & -- & -- & -- \\
\hline 12 & $1: 50$ & -- & -- & -- & -- & -- & $1: 100$ \\
\hline 13 & -- & -- & -- & -- & -- & $1: 100$ & -- \\
\hline 14 & $1: 50$ & $1: 100$ & -- & -- & -- & -- & $1: 50$ \\
\hline 15 & $1: 100$ & -- & -- & -- & -- & -- & $1: 50$ \\
\hline 18 & -- & -- & -- & -- & $1: 50$ & -- & $1: 50$ \\
\hline 20 & -- & -- & -- & -- & -- & -- & $1: 50$ \\
\hline 23 & -- & $1: 50$ & -- & -- & -- & -- & -- \\
\hline 26 & -- & -- & -- & -- & $1: 50$ & -- & $1: 50$ \\
\hline 27 & -- & $1: 50$ & -- & -- & -- & -- & -- \\
\hline 28 & -- & $1: 100$ & -- & -- & -- & -- & $1: 50$ \\
\hline 30 & -- & $1: 50$ & -- & -- & $1: 50$ & -- & $1: 100$ \\
\hline 31 & -- & $1: 50$ & $-\infty$ & -- & -- & -- & -- \\
\hline 32 & -- & -- & -- & -- & -- & -- & $1: 100$ \\
\hline 36 & -- & $1: 200$ & -- & -- & -- & -- & $1: 50$ \\
\hline 37 & -- & $1: 50$ & -- & $-\infty$ & -- & -- & -- \\
\hline
\end{tabular}

*Serotypes ballum, icterohaemorrhagaie, pyrogenes, autumnalis, and ft. bragg share common antigens 
Due to this apparent dependence upon anthropod transmission, the disease is seasonal, occurring in midsummer and disappearing with the onset of frost (Davis et al. 1970).

For this reason, it would seem that June through August, 1971 and 1972, during which 49 blood samples were obtained from northeastern Oregon elk for my study, would be the time of the year especially likely for detecting BTV titers, yet no positive reactivity was found. Manifestations of leptospirosis vary from inapparent to fatal, depending upon the host and serotype involved (Davis et a1. 1970). Abortion induced by serotype pomona has been observed in experimentally infected white-tailed deer (Trainer et a1. 1961), and is believed to occur in those naturally infected (McGowan et al. 1963). Although complete reproductive data were not available for the elk found to be reactive to leptospirosis in this study, al1 16 animals gave the superficial appearance of good health.

Agglutinins elicited by leptospires of a particular serotype often agglutinate leptospires of other serogroups as wel1. As a consequence, the microscopic agglutination test is only relatively serotype-specific (Turner 1968). The low levels of reactivity which I found would indicate that the agglutinins are "residual" in contrast to high levels seen in current infections in deer and calves (Reilly 1962). Significant reactivity was found to serotypes ballum, icterohaemorrhagiae, grippotyphosa, pyrogenes, australis, and fort bragg. Of the $16 \mathrm{elk}$ with a serum titer of 1:100 or greater, indicating infection with a leptospire in the past, six were lactating adult cows, one was a dry adult cow, and nine were yearling animals. Serotype autumnalis elicited 
a titer of 1:50 in three elk, a level not considered significant.

Serotype, sex and age data for elk demonstrating significant titers are summarized in Table XXXVI. Of the 38 elk tested by the microscopic agglutination test, 14 evidenced no serologic response to leptospiral antibodies. Eight elk with titers below $1: 100$ are not included in Table XXXVI. Of the 13 serotypes employed as antigens to detect the presence of leptospiral antibodies, reactivity was not found against the following six: pomona which is common in cattle, canicola which is frequently isolated from dogs, batavia, wolffi, georgia, and tarassovi.

It has been pointed out that infections by canicola are spread by canine sexual activities (Baker et a1. 1962). The bull elk also uses his nose and tongue to investigate female genitalia for evidence of estrous and, during rut, urinates on himself and wallows in muddy pits, behavior conducive to aquatic maintenance of this bacterium. Experimental infections indicate that white-tailed deer are susceptible to transmission of leptospirosis by the intravaginal route (Trainer et a1. 1961).

of the 38 free-1iving elk tested for leptospirosis by the microscopic agglutination method, 18 were adult females, 11 were yearling females, and nine were yearling males. For this reason, the adult male category is not included in Table XXXVI. No evidence regarding an increased incidence of leptospirosis among mature bu11 e1k due to sexual transmission was obtained.

In addition to the potential for sexual transmission, wild animals are believed to become infected more commonly by drinking water con- 
TABLE XXXVI

SEROTYPE, SEX AND AGE DATA FOR ELK WITH POSITIVE AGGLUTINATION TITER OF 1:100 OR HIGHER

\begin{tabular}{lcccccc}
\multicolumn{1}{c}{$\begin{array}{c}\text { Males } \\
\text { Serotype }\end{array}$} & $\begin{array}{l}\text { Yearling } \\
\text { ballum }\end{array}$ & Yearling & Adult & Yearlings & Adults & Totals \\
pyrogenes & 3 & -- & 1 & 3 & 1 & 4 \\
icterohaemorhagiae & -- & -- & 1 & -- & 1 & 1 \\
fort bragg & 2 & 2 & 1 & 4 & 1 & 5 \\
australis & 3 & 1 & 2 & 4 & 2 & 6 \\
grippotyphosa & -- & -- & 3 & -- & 3 & 3 \\
Total Samples & -- & 1 & -- & 1 & -- & 1 \\
Total Positive & 9 & 11 & 18 & 20 & 18 & 38 \\
& 8 & 4 & 8 & 12 & 8 & $20 *$
\end{tabular}

*Some elk demonstrated reactivity to more than one serotype. 
taining leptospires (Davis et a1. 1970). The high percentage of yearling elk among those showing positive titers would suggest that drinking water was the route of infection.

To evaluate the role of elk in the ecology of leptospirosis, it should be ascertained whether, like rodents, they function as maintenance hosts which excrete leptospires for a long period or as incidental hosts with leptospiruria lasting from 18 to 35 days, as was founa in cattle and white-tailed deer by Reilly et al. (1962) and Roth (1964). In the British vole (Clethrionomys), two and a half times as many animals excrete leptospires as carry antibodies (Twigg et al. 1968). Diesch et a1. (1970) reported that macroscopic and microscopic serologic methods failed to detect leptospirosis in Iowa mammals from which leptospires were isolated

CONCLUS IONS

I found no evidence of brucellosis or bluetongue in the elk of this study. However, evidence from other investigators that elk are susceptible to these diseases (Davis et a1. 1970, and Honess 1957) would seem to justify continued surveillance, especially where wild elk share common range with domestic stock.

The positive findings reported here, based on a single diagnostic test for leptospirosis, suggest that further investigations, employing a combination of laboratory procedures, would be conducive to assessing the role of elk in this zoonosis. In view of the evidence for sexual transmission, a particular effort would seem to be indicated to include mature bull elk in future investigations of leptospirosis. 
CHAPTER VIII

\section{HELMINTHIC DISEASES}

The belief has been commonly held, until recently, that parasites of wild animals are so well adapted to their hosts that under "natural conditions" the parasites infrequently cause disease; however, there is little evidence to support this view. What authors previously defined as "natural conditions" may, in today's context, be interpreted differently, espectally in an environment increasingly altered by the activities of man. My interest in studying the parasites of elk is centered on management practices conducive to parasitism and the blological effects of the helminths on their hosts.

Lungworms of the genus Dictyocaulus have been reported by several investigators to occur in elk; the first report being that of Dikmans (1931) who collected Dictyocaulus hadweni Chapin, 1925 from Yellowstone Ntional Park. The type specimens of $\underline{D}$. hadweni were from the American bison, but Chapin (1925) expressed the belief that the species also occurred in elk. Dikmans (1936) reduced $\underline{\text {. hadweni }}$ to synonymy with Dictyocaulus viviparus (B1och, 1782) Rallliet and Henry, 1907. Death of three Ronseve1t elk in the zoo at Sequoia Park, Eureka, California, was attributed by $\operatorname{Orr}$ (1937) to have resulted from "lung flukes" (probably D. viviparus). Barrett and Worley (1966) surveyed for the incidence of Dictyocaulus in three populations of elk, and found that the worm burden was directly correlated with range use which produced conditions favorable for the propagation and transmission of this 1ungworm. Dunn (1969) discussed the possible synonymy of $\underline{D}$. viviparus 
in cattle and D. eckerti Skrjabin, 1931 in European cervids. Because the elk of my study share common pasture with domestic cattle, the work of Presidente et al. (1972) in which they conducted cross-transmission experiments of Dictyocaulus viviparus between elk and cattle is significant. They found that infective larvae from elk did not develop a patent infection in Holstein calves, but that a patent infection was established in an elk calf after oral inoculation with larvae from cattle.

Numerous surveys have been done on the parasites of Rocky Mountain elk from the southwestern United States. Thysanosoma actinioides, Trichuris sp., and Ostertagia sp. were found to occur in elk from Yellowstone Park, Wyoming (Mills 1936). Elk from the Jackson Hole area of Wyoming were studied by Alders on (1949) who reported on four species of protozoan, the cestode, Thysanosoma actinioides, two nematodes of the respiratory passages, Dictyocaulus hadweni (D. viviparus) and Protostrongylus macrotis, and six nematodes of the alimentary tract including Capillaria sp., Ostertagia circumcincta, Nematodirus spathiger, Strongyloides sp. and Trichuris ovis. In their study of the wildiffe diseases of Wyoming, Honess and Winter (1956) described Ostertagia circumcincta, 으 trifurcata, Nematodirus filicollis, N. spathiger, Dictyocaulus, and cysticerci of Taenia hydatigena from elk. Wilson (1969) examined $22 \mathrm{elk}$ in New Mexico and found Thysanosoma actinioides, Dictyocaulus viviparus, Elaeophora schneideri, Trichostrongylus axei, as well as two nematodes not previously reported from elk, TrichostrongyIus colubriformis and Ostertagi ostertagi.

The giant liver fluke, Fascioloides magna, found in my study, was 
described by Swales (1935) from elk in Alberta, Canada. A checklist of helminths from North American ruminants prepared by Dikmans (1939) named $\mathrm{F}$. magna, as well as Dictyocaulus viviparus, Oesophagostomum venulosum, Ostertagia circumcincta, Setaria sp., and Echinococcus sp. as parasites of $\mathrm{elk}$.

The only study of which I am aware on the parasites of Roosevelt elk is that of Schwartz and Mitchell (1945) who examined thirty-two specimens of the West Coast subspectes from the 0lympic peninsula of Washington. They found Dictyocaulus viviparus, Oesophagostomum venulosum, Trichuris sp., Thysanosoma actinioides, and Fascioloides magna.

Due to the universal distribution of some of the nematodes found in my study, and the possible synonymy of the American elk with its old World counterpart, Cervus elaphus, the investigation of Jansen (1960) is of interest. Among the parasites Jansen reported from red deer in the Netherlands were Trichostrongylus axei and Ostertagia sp. Jansen (1963) described Oesophagostomum venulosum and Dictyocaulus enterti from red deer, and observed that $\underline{D}$. eckerti was indistinguishable morphologically from $D$. viviparus. He expressed the view that the genus Ostertagia exhibited a low degree of host specificity, and that Trichostrongylus axei was one of the few parasites which passed easily from deer to domestic animals and from these to deer in return. Eveleth and Bolin (1955) expressed the opinion that parasitic gastritis assoclated with Trichostrongylus axei caused the death of a captive elk cow and calf kept on a Minnesota farm. Worley et al (1969) reported on their investigations of elk in western Montana as a possible 
reservoir host for parasites of domestic animals.

The problem of helminthiasis in ruminants in zoos is discussed by Sloan (1965) with recommendations for control of some of the genera found in my study.

METHODS AND MATERIALS

Two general procedures were employed in detecting the presence of internal helminths. The first was the post-mortem examination of internal organs from 37 hunter-killed and two disease-killed Roosevelt elk in western Oregon; the second was the microscopic study of fecal samples obtained from seven living Roosevelt and 49 Rocky Mountain elk from five counties of the state, and from 26 elk held captive in zoos. The abomasa of $37 \mathrm{elk}$ were securely tied at the omasum-abomasum juncture and at the pyloric valve region, then preserved with buffered $10 \%$ formalin injected into the lumen of the organ and stored in metal tanks containing formalin. In the laboratory, each abomasum was opened and the mucosal walls scraped to free parasitic worms that might be deep in the crypts of the gastric villi. The abomasal contents were washed through a No. 100 Tyler screen until the water flowing from the screen was clear in color. The material remaining in the screens was transferred to a $3,000 \mathrm{ml}$ beaker and enough water added to factlitate complete mixing with a magnetic stirrer. Three sample aliquots of $50 \mathrm{ml}$ each were withdrawn from the material during stirring. The contents of each aliquot were poured into Petri dishes and examined under a dissecting microscope for the presence of parasites. The numbers found in the three aliquots were averaged and multiplied by the factor 
derived in sampling to obtain the figure for total number of parasites present.

In March 1972, the bodies of two yearling male elk were collected at Jewell Wildlife Meadows within six hours of their deaths. The lungs and associated structures were immediately removed from the animals, and examined grossly for adult worms by opening the tracheae and incising the respiratory tree to the numerous apices within the lungs. The caecum, large intestine, small intestine, and abomasum of both elk examined for lungworms were also examined for gastrointestinal parasites by the screening and aliquot method described above.

Examination for the presence of cestodes included visual inspection of the opened intestinal tract for the presence of adult worms, microscopic scrutiny of material recovered after washing the intestinal tract contents through a series of screens for the presence of proglottids, and direct examination of microscope slides prepared from fecal samples from living elk for the presence of ova. No evidence of cestode infection was found.

Examination for the presence of trematodes concentrated on searching for the giant liver fluke, Fascloloides magna. The black pigment and fibrous cyst associated with the presence of F. magna facilitates field detection of this parasite. The grit-like substance adherant to the cyst also aids detection. Elk hunters usually retained the liver from the animal they killed, but allowed me to examine the organ visually. Livers collected for laboratory examination were sliced through at one centimeter intervals. Microscope slides were prepared of fecal samples from living elk and examined for the presence of trematode 
eggs •

The McMaster egg-counting technique (Soulsby 1969:789) for counting nematode eggs in fecal samples was modifled by increasing the dilution factor to compensate for the low numbers of eggs present.

Dr. T. P. Kisner, Department of Veterinary Medicine, Oregon State University, Corvallis, Oregon, confirmed my identifications of Trichostrongylus axei and Oesophagostomum venulosum. Dr. J. Ralph Lichtenfels, National Animal Parastte Laboratory, Beltsville, Maryland, confirmed my identifications of Dictyocaulus viviparus and Ostertagia circumcincta.

RESULTS

Two yearling male elk which appeared to have died from the effects of verminous pneumonia yielded the 1 ungworm, Dictyocaulus viviparus, in numbers that ranged from 1,900 to 2,175 adult worms per host.

The data obtained from the abomasal examinations of 37 hunterkilled Roosevelt elk are summarized in Tables XXXVII and XXXVIII. Of these $37 \mathrm{elk}$, two (5\%) had only Trichostrongylus axel, and six (16\%) had only Ostertagia circumcincta. Mixed infection of both species was found in $25(68 \%)$ of the elk, and four (11\%) were free of abomasal nematodes.

As noted in Table XXXVII, the giant fluke (Fascioloides magna) was found in nine of the 37 Roosevelt elk examined for abomasal parasites.

Adults of Oesophagostomum venulosum were recovered from both elk that died of lungworm disease. 
TABLE XXXVII

TOTAL NUMBERS OF ABOMASAL PARASITES RECOVERED

FROM 37 ROOSEVELT ELK

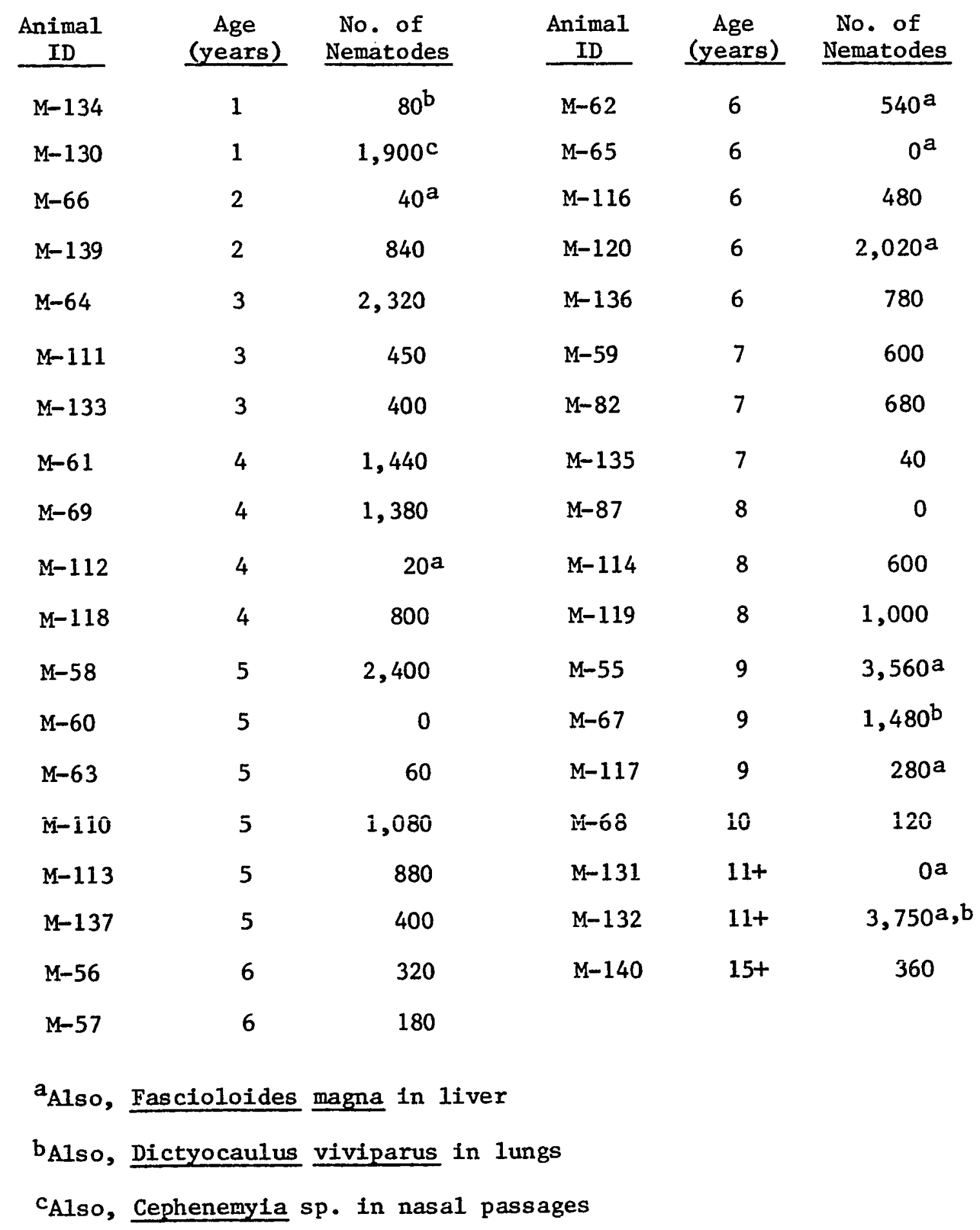


TABLE XXXVIII

SPECIES AND PERCENTAGES OF ABOMASAL NEMATODES FOUND IN 37 ROOSEVELT ELK

\begin{tabular}{|c|c|c|c|c|c|}
\hline $\begin{array}{c}\text { Animal } \\
\text { ID } \\
\end{array}$ & $\begin{array}{c}\text { Ostertagia } \\
\text { circum- } \\
\text { cincta } \\
\end{array}$ & $\begin{array}{c}\text { Tricho- } \\
\text { strongy lus } \\
\text { axel } \\
\end{array}$ & $\begin{array}{c}\text { Animal } \\
\text { ID } \\
\end{array}$ & $\begin{array}{c}\text { Ostertagia } \\
\text { circum- } \\
\text { cincta } \\
\end{array}$ & $\begin{array}{c}\text { Tricho- } \\
\text { strongylus } \\
\text { axei } \\
\end{array}$ \\
\hline$M-134$ & $100 \%$ & -_b & $M-62$ & $100 \%$ & $--^{a}$ \\
\hline$M-130$ & $95 \%$ & $5 \% c$ & $M=-65$ & -- & $--a$ \\
\hline$M-66$ & $100 \%$ & $--a$ & $M-116$ & $80 \%$ & $20 \%$ \\
\hline$M-139$ & $60 \%$ & $40 \%$ & $M-120$ & $5 \%$ & $95 \%^{a}$ \\
\hline$M-64$ & $75 \%$ & $25 \%$ & $M-136$ & $50 \%$ & $50 \%$ \\
\hline$M-111$ & $70 \%$ & $30 \%$ & M-59 & $25 \%$ & $75 \%$ \\
\hline$M-133$ & $70 \%$ & $30 \%$ & $M-82$ & $10 \%$ & $90 \%$ \\
\hline$M-61$ & $60 \%$ & $40 \%$ & M-135 & - & $100 \%$ \\
\hline M-69 & $40 \%$ & $60 \%$ & $M-87$ & -- & -- \\
\hline$M-112$ & -- & $100 \% a$ & $M-114$ & $50 \%$ & $50 \%$ \\
\hline$M-118$ & $70 \%$ & $30 \%$ & $M-119$ & $60 \%$ & $40 \%$ \\
\hline$M-58$ & $100 \%$ & -- & $M-55$ & $30 \%$ & $70 \% a$ \\
\hline$M-60$ & -- & -- & $M-67$ & $60 \%$ & $40 \% b$ \\
\hline$M-63$ & $30 \%$ & $70 \%$ & M-117 & $100 \%$ & $--^{a}$ \\
\hline$M-110$ & $95 \%$ & $5 \%$ & $14-68$ & $25 \%$ & $75 \%$ \\
\hline$M-113$ & $25 \%$ & $75 \%$ & $M-131$ & - & $--^{a}$ \\
\hline$M-137$ & $95 \%$ & $5 \%$ & $M-132$ & $10 \%$ & $90 \% a, b$ \\
\hline$M-56$ & $100 \%$ & - & $M-140$ & $40 \%$ & $60 \%$ \\
\hline$M-57$ & $50 \%$ & $50 \%$ & & & \\
\hline
\end{tabular}

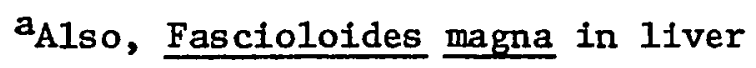

${ }^{b}$ Also, Dictyocaulus viviparus in lungs

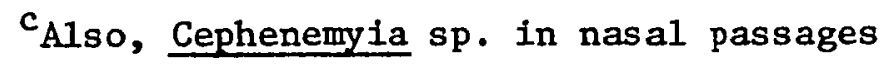




\section{DISCUSSION}

Two yearling male elk died at the Jewell Meadows Wildlife Refuge in March, 1972. From the lungs of the first elk examined, a total of 2,175 Eictyocaulus viviparus were counted. From the second animal, the number was estimated to be between 1,900 and 2,000 worms. There seems little doubt that in both cases the cause of death was verminous pneumonia. Rarely was an air passage examined that was not occluded by worms. In addition to the blockage due to the physical presence of great numbers of nematodes, the respiratory bronchioles were filled with cellular debris and frothy exudate which undoubtedly interfered with pulmonary function. Serous atrophy of mesenteric fat was noted, and the contents of the rectal portion of the gastrointestinal tract were fluid and diarrhetic. Both animals appeared to be fat and in good bodily condition, suggesting the speed with which mortality had occurred. Conditions conducive to ingesting large numbers of infective lungworm larvae had obviously arisen. One explanation as to how this occurred could lie with the practice of distributing alfalfa hay directly on the ground where it became contaminated with infective larvae. Access to easlly available food encouraged the elk to congregate and continue to return to the same place daily to feed. Ordinarily, Roosevelt elk have a well-established pattern of dispersal and movement within their home range. They feed in one locality for 1 to 3 days and then move on, not returning to the same area for 15 to 20 days (Harper 1966). They forage on a wide variety of plant species, including the evergreen leaves of Rubus which are high off the ground. Elk are both browsers 
and grazers. Thus, the opportunity to ingest larvae which are most commonly on ground crops is reduced by natural behavioral characteristics. Van Volkenberg and Nicholson (1943), in their study of the relationship between gastrointestinal nematodes and malnutrition in deer in Texas, found that when deer are forced to subsist on grass, they ingest infective larvae, which would not be true if they were utillzing browse which is their preferred food.

It is apparent that an abundance of infective larvae were available to the elk. Perhaps it would be productive to investigate the possible role of the fungus Pilobolus spp. (Phycomycetes: Mucorales) in dispersing the larvae of Dictyocaulus viviparus, as discussed by Poynter and Selway (1966). It is not known if this fungus occurs in western Oregon or is a factor in the transmission of lungworm larvae to Roosevelt elk.

In addition to the lungworms recovered from the two yearling males, the abomasa of both elk showed light mixed infections of Trichostrongylus axei and Ostertagia circumcincta. Both are common in domestic ruminants, and have been reported from many wild ungulates of the families Bovidae, and Cervidae and Antilocapridae (Dunn 1969). Abomasa from 33 of 37 hunter-k1lled Roosevelt elk yielded either one or both of these nematodes (Tables XXXVII and XXXVIII).

The pathogenesis of Trichostrongylus is not completely understood (Levine 1968). It must be noted that in studies of the pathology assoclated with this nematode in domestic ruminants, the total worm numbers recovered at autopsy from severely affected animals are in the order of 6,000 to 200,000 worms (Leland et a1. 1958; 1959; 1960), which 
greatly exceeds the numbers I found in elk.

Where it exists in high numbers, Ostertagia is also pathogenic; infections of 8,000 or more have been associated with the death of sheep. Spectes of this genus ingest blood, although apparently not to the same extent as Haemonchus. As with other parasitic infections, affected animals are belleved to be harmed to a greater or lesser extent, but not killed (Levine 1968).

The opportunity to ingest larvae cf both Trichostrongylus axei and Ostertagia circumcincta would occur in areas grazed by $68 \%$ of the 37 elk included in Tables XXXVII and XXXVIII. Evidence exists that mixed infections of Trichostrongylus and Ostertagia are markedly more injurious to bovine calves then single infections with the same number of larvae of either species (Levine 1968). If this increased pathogenicity is true for elk calves as well, they are at a disadvantage, based on the findings of my investigation. Optimal conditions for pasture transmission of Trichostrongylus and Ostertagia exist where mean monthly precipitation is $5 \mathrm{~cm}$ (2 inches) or more, and mean monthly temperature is $6-20^{\circ} \mathrm{C}\left(43-68^{\circ} \mathrm{F}.\right)$. Bioclimatographs illustrate that this is true in Salem, Oregon (Levine 1968:32), and therefore likely to be true in many of the areas inhabited by Roosevelt elk. Larvae of trichostrongyles may be present in the mucosa of the host throughout winter; they mature and produce eggs in the spring, with a resultant "spring rise" in fecal egg counts frequently observed in domestic ruminants (Levine 1968).

Associated with infection of Ostertagla circumcincta in sheep, Horak et al. (1965) noted a marked difference in the color of the 
abomasal ingesta. Whereas the ingesta of their control sheep was a constant brown, that of the parasitized sheep was green and appeared to be undigested. This description parallels the condition I found present with the mixed infection of the two most heavily parasitized elk in the group, $M-55$ and $M-132$. The latter animal was estimated to be between 11 and 15 years of age by the Quimby and Gaab (1957) technique. Teeth which are worn down with age could have contributed to the poorly digested plant material I found. For the younger elk, however, parasitism may have interfered with digestion. It has been found in bovines that, coincident with abomasal parasitism, the $\mathrm{pH}$ of the contents increases, the pepsin concentration decreases, and changes occur in the mucous and zymogen celis (Levine 1968), all of which could adversely affect stomach function and contribute to the presence of undigested food. In addition, the mucosa of the abomasal walls of M-132 had a thickened, corrugated, leathery appearance. In domestic ruminants, Trichostrongylus axei has been associated with metaplasia, sloughing of the epithelium, and gross lesions of the abomasum (Levine 1968), which leads me to believe that the 3,750 nematodes recovered from $M-132$ produced a similar response in this elk.

Adults of the nematode 0esophagostomum venulosum were recovered from the large intestine of both elk that dies of verminous pneumonia. The first animal examined had a total burden of 780 worms of this species. For the second elk, 390 worms were estimated to be present. The nodular formation of the intestinal wall that is commonly associated with infection by this genus was not observed in either animal. In domestic ruminants, Oesophagostomum venulosum is believed to be relatively 
harmless; the host reaction that gives rise to large nodules is more commonly seen in infections with o. columbianum (Levine 1968).

Examination of fecal pellets which were obtained directly from the rectum of living elk disclosed trichostrongyloid eggs present in $50 \%$ of the animals. This was true of captive zoo elk in apparent good health as well as free-living elk. Eggs per gram of feces commonly numbered between five and ten, suggesting a low level of parasite burden. Egg counts, however, are not necessarily proportionate to the degree of infection. Volume and texture of the feces influence egg counts, as does the species of parasite involved. For instance, the western stomach worm, Ostertagia clrcumcincta, produces only 200 to 300 ova per day (Knapp 1968). Gastrointestinal nematodes may be present in the host despite the absence of ova at a single examination. An observation made during this study regarding the relationship of elk to their environment appears to be significant. Fecal examinations were done at all times of the year, and the common appearance of the pellet was firm, ovold and brown, with a slightly shiny surface. A change in the appearance of the feces of the free-living elk occurred in the spring of each year, associated with the change in forage. As described in Chapter $I$, Rocky Mountain $21 \mathrm{k}$ move up to mountain meadows Where they browse on the newly emerging green tips of shrubs and forbs. Similarly, in spring, Roosevelt elk graze less along the grassy river bottoms they occupied in winter, and seek, instead, the browse species which turn the surrounding hillsides green. With the ingestion of large quantities of lush herbage, the pellet becomes amorphous and green. Helminth eggs were rarely found in this type of pellet, despite the 
potential for the "spring rise" phenomenon earlier discussed. It is possibie that this marked change in diet exerts a cathartic action which aids in expelling gastrointestinal parasites. In addition, the plant species ingested in browsing are virtually inaccessib ie to helminth infective stages, so new infections would rarely occur.

The normal behavioral patterns of movement and forage by freeliving elk are sometimes interrupted or modified by land use practices such as clear-cutting and logging road construction. Human activities that interfere with the free movement of elk could be detrimental from the viewpoint of increased parasitism.

CONCLUSIONS

The significance of the lungworm fafection described here lies in the extraordinary numbers of Dictyocaulus viviparus recovered, which exceeds the numbers reported from a wild cervid by other authors. Modiflcations of an animal's environment by man, including those associated with artificial feeding, have the potential to increase the opportunity for severe lungworm infections in elk beyond the capacity of the host to resist.

This is the first report of Trichostrongylus axef or Ostertagia circumcincta from Roosevelt elk.

Because the simple presence of trichostrongyloids in an animal means very little (Dunn 1968), it is unlikely that an assessment of pathogenicity in elk can be based on the demonstrated incidence of these parasites, without supplemental clinical evidence of disease. 
CHAPTER IX

TICKS

Many investigators who have dealt with the subject of endoparasitism and other disease states in elk gave attention to ectoparasites as we11. Cameron and Fulton (1927) discussed an outbreak of the winter or moose tick, Dermacentor albipictus, in Canada and described its life history. Schwartz (1943) characterized D. albipictus as the most widely distributed and common parasite found on Roosevelt elk of the Olympic peninsula.

Murie (1951b) expressed the view that although Dermacentor albipictus will swarm over a person who is handling an infested elk carcass, that tick will not accept a human host. During a one year test period, all of the ticks Murie found on human beings were Dermacentor andersoni, the spotted fever tick, a species that he stated was not found on the elk. In contrast to Murie's statements, however, Bishopp and Trembley (1945) listed elk among the hosts for D. andersoni, based on records of the Bureau of Entomology and Plant Quarantine.

In his description of D. albipictus infestation on elk of E1k Is land National Park, Alberta, Canada, Love (1955:191) stated that almost every animal discovered sick or dead in the winter of 1936-7 was host to thousands of ticks. Love quoted Professor Strickland of the University of Alberta as saying that a heavy tick load was 
responsible for most of the deaths. This view was supported by the result of acaricide treatment given to weakened and comatose elk. After 24 to 48 hours, dead ticks fell from the elk in large numbers. Most of the treated elk began to eat voraciously and were soon on their feet and away.

Cooley and Kohls (1943) described Ixodes pacificus as a new species, found in the western United States. Bishopp and Trembley (1945) drew upon the Cooley and Kohls nomenclature in their review of the distribution and hosts of North American ticks. Arthur and Snow (1968) included an extensive host 1ist with their discussion of the life-history and occurrence of Ixodes pacificus.

Gratitude is expressed to Dr. Emmett Easton of the Department of Entomology at Oregon State University for his aid with the tick identifications.

METHODS

A cursory survey for ectoparasites was done at the time blood samples were obtained and internal organs collected from elk. On the najority of the elk examined, careful searching was required to find small numbers of ticks, which were commonly attached to the thin skin of the anal and abdominal areas. Auditory and nasal passages were not examined.

The electrophoretic procedure employed in this study for separation and quantification of serum proteins is described in detail in Chapter V. 
RESULTS

Table XXXIX lists the numbers and species of ticks found on the seven elk of southwestern Oregon, which I believe to be illustrative of the annual burden of ticks to which Roosevelt elk are likely to be subjected in the months of January, February and March

This is the first reported finding of Ixodes pacificus from elk (Arthur and Snow 1968). Ixodes pacificus Cooley and Kohls 1943 is synonomous with Ixodes ricinus californicus Banks 1904 and has been described from Columbian black-tailed deer (Bishopp and Trembley 1945).

An interesting parallel to their tick infestation is reflected in the pattern of serum protein values for seven Roosevelt elk listed in Table Xl with their age, sex and identification number. Four of these seven animals, Nos. 16, 17, 18 and 19, had gamma globulin values among the highest recorded for the $72 \mathrm{elk}$ in my study. These four had high total protein levels, and low albumin/globulin ratios of 0.72 , $0.92,0.96$ and 0.92 , respectively.

One emaciated Roosevelt elk cow I had the opportunity to examine in early spring of 1971 had the heaviest infestation of Dermacentor albipictus encountered during this study. The entire dorsal surface, from neck to tail, was a continuous series of engorged ticks interspersed within the coarse, roughened pelage, with as many as three to five attached ticks per square inch of skin surface. The landowner had called the State Game Commission for aid in disposing of the animal which was moribund on a pasture near Brownsmead, Clatsop County, Oregon. Field autopsy before disposal of the carcass, and subsequent laboratory 
TABLE XXXIX

TICKS TAKEN FROM FREE-IIVING

ROOSEVELT ELK

Anima 1

Number

Date

Species

Number and Sex

$$
8
$$

$$
1-28-71
$$

Dermacentor albipictus

8 females

10 males

9

$$
1-28-71
$$

Dermacentor albipictus

11 females

1 male

Dermacentor

albipictus

3 females

2 males

1 nymph

Ixodes pacificus

2 females

1 male

16

$3-2-71$

Dermacentor albipictus

1 female

1 nymph

17

$3-2-71$

Dermacentor albipictus

Ixodes pacificus

18

$3-2-71$

Dermacentor albipictus

Ixodes pacificus

19

Dermacentor albipictus

Ixodes pacificus

1 female

1 male

5 females (engorged)

1 female

2 females

2 males

4 females

3 males

2 females

1 male 
TAELE XL

SERUM PROTEIN VALUES OF TICK-INFESTED ROOSEVELT ELK

\begin{tabular}{|c|c|c|c|c|c|c|c|}
\hline Anima1 Number & $\underline{8}$ & $\underline{9}$ & $\underline{10}$ & $\underline{16}$ & $\underline{17}$ & $\underline{18}$ & 19 \\
\hline Sex & Eemale & female & male & female & female & female & female \\
\hline Age & 8 yrs. & 18 mos. & $2 \frac{1}{2}$ yrs. & $8-10$ yrs. & 6 yrs. & $3 \frac{1}{2}$ yrs. & $2 \frac{3}{2}$ yrs. \\
\hline Total protein (g\%) & 7.28 & 7.00 & 7.60 & 8.20 & 8.20 & 8.40 & 8.80 \\
\hline Albumin (g\%) & 3.94 & 4.20 & 4.41 & 3.44 & 3.93 & 4.12 & 4.22 \\
\hline Alpha $_{1}$ globulin $(g \%)$ & 0.07 & 0.14 & 0.00 & 0.00 & 0.08 & 0.00 & 0.00 \\
\hline Alpha $_{2}$ globulin ( $\left.g \%\right)$ & 0.36 & 0.84 & 0.46 & 0.57 & 0.57 & 0.76 & 1.14 \\
\hline Beta globulin ( $\mathrm{g} \%)$ & 1.67 & 1.26 & 1.60 & 0.98 & 0.66 & 0.92 & 0.97 \\
\hline Gamma globulin ( $g \%)$ & 1.24 & 0.56 & 1.14 & 3.20 & 2.95 & 2.60 & 2.46 \\
\hline Total globulin $(g \%)$ & 3.34 & 2.79 & 3.20 & 4.75 & 4.26 & 4.28 & 4.57 \\
\hline Albumin/globulin ratio & 1.17 & 1.50 & 1.37 & 0.72 & 0.92 & 0.96 & 0.92 \\
\hline
\end{tabular}


examination of the internal organs, disclosed no further evidence as to the probable cause of death.

The Rocky Mountain elk which I examined in summer and fall had far fewer ticks than the Roosevelt elk which I examined during winter months. At all times of the year, the zoo elk were free of ticks.

DISCUSS ION

Bishopp and Trembley (1945) expressed the opinion that e1k and moose in North America die from gross infestations of the winter tick, Dermacentor albipictus, in combination with food shortages in late winter and early spring. In all likelihood, similar circumstances brought about the death of the cow elk I examined.

Surveillance for evidence of mortality associated with tick infestation would seem to be justified, especially in localized areas where elk numbers are increasing and the nearby vegetation may thus become increasingly "seeded down" with tick larvae.

The finding of few ticks on Rocky Mountain elk coincides with what one might expect, based on what is known regarding the seasonal cycle of Dermacentor albipictus, the common tick of elk. The larvae of this species attach to the host in autumn and both molts occur on the same host during winter. By spring, the engorged females have dropped to the ground to lay their eggs (Cameron and Fulton 1927). Thus, the summer and fall is not the best time of year to find this species on the host.

It is reasonable that antibody response to tick infection contributes to the gamma globulin component of elk serum proteins. This 
fraction was especially elevated in the 8-10 year old cow, which had the longest time of these seven elk to acquire immune factors. By contrast, the eighteen-month-old female had the lowest gamma globulin level in the group. Although she was carrying ticks, it may be that she had not yet developed a serum response to their presence.

A similar pattern of host protein response to the presence of an ectoparasite is described in a study by Payne et al. (1967). Plasma from eastern chipmunks (Tamias striatus) and white-footed mice (Peromyscus leucopus) which had Cuterebra infestations was compared by electrophoresis with plasma from captive animals of the same species which did not suffer from the presence of this larva. Their observations regarding a marked depression in the albumin/globulin ratio of infested animals parallel what I found to be true with tick infestation of elk.

CONCLUSIONS

A new host record is established for Ixodes pacificus, based on both male and female specimens, as cited in Table XXXIX.

A relationship between the quantity and distribution of serum proteins in the host animal and expnsure to parasitic and infectious agents in the environment has been postulated by other authors (Campbe11 1960; Grobov 1961; Leland 1961; Stauber 1954; and Woolf et al. 1973). The findings summarized in Table XL appear to support the hypothesis that tick infestation elicits a serum protein response in elk that can be demonstrated by electrophoresis. 


\section{REFERENCES}

Abdulla, P. K., I. Karstad, and N. A. Fish. 1962. Cultural and serological evidence of leptospirosis in deer in Ontario. Can. Vet. J. 3:71-78.

Abrams, J. T. 1968. Fundamental approach to the nutrition of the captive wild herbivore. Symp. Zool. Soc. London 21:41-62.

Albanese, A. A., L. A. Orto, and D. N. Zavattaro. 1958. Biochemical significance of plasma amino nitrogen in man with a comparison of other criteria of protein metabolism. Metabolism 7:256-268.

Alderson. L. E. 1949. Internal parasites of the elk in Wyoming. M. S. Thesis. Univ, of Wyoming. 73pp.

Allcroft, W. M., and R. Strand. 1933. Studies on the lactic actd, sugar and inorganic phosphorus of the blood of ruminants. Biochem. J. 27:512-522.

Anderson, A. E., D. E. Medin, and D. C. Bowden. 1972a. Total serum protein in a population of mule deer. J. Mammal. 53(2):384-387.

- 1972b. Blood serum electrolytes in a Colorado mule deer population. J. Wild1. Dis. 8(2): 183-190.

- 1970. Erythrocytes and leukocytes in a Colorado mule deer population. J. Wildl. Manage. 34(2):389-404.

Anonymous. 1936. Some observations and study on the life of wild animals in captivity. Indian Wildl. 1:70-76.

Arthur, D. R., and K. R. Snow. 1968. Ixodes pacificus Cooley and Koh1s, 1943: Its 1ife-history and occurrence. Parasitology 58: 893-906.

Aylward, F. X., and J. H. Blackwood. 1936a. Fasting and realimentation in the ruminant. I. The effect of food and fasting on certain blood constituents. Blochem. J. 30:1819-1824.

- 1936b. Fasting and realimentation in the ruminant. II. Calcium and phosphorus metabolism during fasting, and during realimentation following fasting. Biochem. J. 30:1824-1832.

Babudieri, B. 1958. Animal reservoirs of leptospires. New York Acad. Sci. Annals $70(3): 393-413$. 
Baily, V. 1936. The mammals and life zones of Oregon. U. S. Department of Agriculture, Bureau of Biological Survey. North American Fauna, No. 55. Washington, D. C. 416pp.

Baker, M. F., G. J. Dills, and F. A. Hayes. 1962. Further experimental studies on brucellosis in white-tailed deer. J. Wildl. Manage. 26:27-31.

Bandy, P. J., W. D. Kitts, A. J. Wood, and I. M. Cowan. 1957. The effect of age and the plane of nutrition on the blood chemistry of the Columbian black-tailed deer. Can. J. Zool. 35:283-289.

Barrett, R. E., and D. E. Worley. 1966. The incidence of Dictyocaulus sp. in three populations of elk in south-central Montana. J. W11d1. Dis. 2:5-6.

Becklund, W. W. 1964. Revised check list of Internal and external parasites of domestic animals in the United States and possessions and in Canada. Am. J. Vet. Res. 25:1380-1416.

- 1963. Helminths of ruminants: geographic distribution and economic importance. U. S. Livest. Sanit. Assoc. 67th Annual Proc. 523-532.

Becklund, W. W., and M. L. Walker. 1971. Nomenclature and morphology of Ostertagia trifurcata Ransom, 1907, with data on spicule lengths of five stomach worms of ruminants. J. Parasitol. $57(3): 508-516$.

- 1968. Ostertagia dikmansi sp. n. (Nematoda: Trichostrongy1idae) from deer, Odocoileus virginianus, with a key to the species of medium stomach worms of Odocoileus in North America. J. Parasitol. 54:441-444.

- 1967. Redescriptions of the nematodes Ostertagla bisonis Chapin, 1925, of cattle and wild ruminants, and Ostertagia mossi Dikmans, 1931, of deer. J. Parasito1. 53: 1273-1280.

Bellamy, D. 1970. Aging and endocrine responses to environmental factors. With particular reference to mammals. Soc. Endocrinol. Mem. 18:303-339.

Bide, R. W., and M. E. Tumbleson. 1970. Changes in the blood chemistry profilles induced by grain-feeding of cattle. Advan. Auto. Analy. 157-160.

Bishopp, F. C., and H. L. Trembley. 1945. Distribution and hosts of certain North American ticks. J. Parasitol. 31:1-54. 
Blaxter, K. L., and J. A. F. Rook. 1956. Experimental magnesium deficiency in calves. II. The metabolism of calcium, magnesium and nitrogen and magnesium requirements. J. Comp. Pathol. Therapeutics 64(2):176-186.

Blinko, C., and W. B. Dye. 1958. Serum transaminase in white muscle disease. J. Anim. Sci. 17:224.

Blunt, F. M. 1959. A study of the nutritive value of flavonoid compounds in game animal rations. Wyoming Game and Fish Comm. P-R Proj. Rep., W-69-R-1. 18pp. Multilith.

Boddicker, M. L., and E. J. Hugghins. 1969a. Helminths of big game mammals in South Dakota. J. Parasitol. 55(5):1067-1074.

- 1969b. Roundworms and tapeworms in wild game animals of South Dakota. Farm and Home Res. 20(3):18-19.

Boyd, R. J. 1970. Elk of the White River Plateau, Colorado Tech. Pub1. No. 25. Colorado Div. Game, Fish and Parks. 126pp.

Braun, W. 1946. Average levels of various constituents, physical properties, and formed elements in the blood of cows on pasture. Am. J. Vet. Res. 7:450-454.

Browman, L. G., and H. S. Sears. 1955. Erythrocyte values, and alimentary canal $\mathrm{pH}$ values in the mule deer. J. Mammal. $36(3): 474-477$.

Busch, L. A. 1970. Epizjotiology and epidemiology of leptospirosis. J. Wild1. Dis. 6:273-274.

Cameron, A. E., and J. S. Fulton. 1927. A local outbreak of winter or moose tick, Dermacentor albipictus, Pack. (Ixodoidea) in Saskatchewan. Bul1. Ențomo1. Res. 17(3):249-353.

Campbe11, E. A. 1960. The use of paper electrophorests as an aid to diagnosis. Am. J. Vet. Res. 3:345-353.

Chandler, A. C., and C. P. Read. 1966. Introduction to parasitology. John Wiley \& Sons, Inc., New York, N. Y. 822pp.

Chapin, E. A. 1925. New nematodes from North American mammals. J. Agric. Res. 30(7):677-681.

Chien, S., R. J. Dellenback, S. Usami, and M. I. Gregersen. 1965. Plasma trapping in hematocrit determination. Differences among animal species. Proc. Soc. Exp. Bio. Med. 119-1155. 
Choquette, L. P. E. 1956. Significance of parasites in wildlife. Can. J. Comp. Med. Vet. Sci. 20(11):418-426.

Chow, B. F. 1947. The correlation between the albumin and alpha globulin contents of plasma. J. Clin. Invest. 26:883-886.

Church, D. C. 1972. Digestive physiology and nutrition of ruminants. Vo1. 3. Practical nutrition. 0.S.U. Book Stores, Inc., Corvallis, Oregon. 350pp.

- 1969. Digestive physioloby and nutrition of ruminants. Vo1. 1. Digestive physiology. 0.S.U. Book Stores, Inc., Corvallis, Oregon. 316pp.

Church, D. C., G. E. Smith, J. P. Fontenot, and A. T. Falston. 1971. Digestive physiology and nutrition of ruminants. Vol. 2. Nutrition. O.S.U. Book Stores, Inc., Corvallis, Oregon. 400pp.

Cohen, L., J. Block, and J. Djordjevich. 1967. Sex related differences in isozymes of serum lactic dehydrogenase. Proc. Soc. Exp. Bio. Med. 126:55-60.

Colby, R. W., J. H. Ware, J. P. Baker, and C. M. Lyman. 1950. The relationship of various blood constituents to rate of gain in beef cattle. J. Anim. Sci. 9:652.

Cooley, R. A., and G. M. Kohls. 1943. Ixodes caliiornicus Banks, 1904, Ixodes pacificus N. Sp., and Ixodes conepati N. Sp. (Acarina: Ixodidae). Pan-Pacif1c Entomo1. 19:139-144.

Cornelius, C. E. 1969. Animal models -- a neglected medical resource. New England J. Med. 281:934-944.

Corner, A. H., and R. Conne11. 1958. Brucellosis in bison, elk and moose fin Elk Is land National Park, Alberca, Canada. Can. J. Comp. Med. Vet. Sci. 22(1):9-20.

Cowan, I. M., and P. A. Johnston. 1962. Blood serum protein varlations at the species and subspecies level in deer of the genus odocolleus. Systematic Zoo1. $11(3): 131-138$.

Daubney, R. 1920. The 1ife-histories of Dictyocaulus filaria (Rud.), and Dictyocaulus viviparus (Bloch). J. Comp. Pathol. Therapeutics 33(4):225-266.

Davidsohn, I., and B. B. Wells, eds. 1962. Todd-Sanford clinical diagnosis by laboratory methods, 13th ed. W. B. Saunders, Philadelphia, Pa. 1020pp. 
Davis, J. W., and R. C. Anderson. 1971. Parasitic diseases of wild mammals. Iowa State Univ. Press, Ames, Iowa. 364pp.

Davis, J. W., L. H. Karstad, and D. O. Trainer. 1970. Infectious diseases of wild mammals. Towa State Univ. Press, Ames, Iowa. $421 \mathrm{pp}$.

Davis, R. I., A. H. Lawton, C. H. Barrows, and S. M. Hargen. 1966. Serum lactate and lactic dehydrogenase levels of aging males. J. Geronti. 21:571-574.

Dean, R., W. W. Hines, and D. C. Church. 1973. Immobilizing freeranging and captive deer with phencyclidine hydrochloride. J. Wild1. Manage. 37(1):82-86.

Denney, R. N. 1965a. Mortality factors affecting deer and elk herds. Colorado Div. Game, Fish and Parks. P-R Proj. Rep., W-38-R-18. 4pp. Multilith.

- 1965b. Deer, elk and brucellosis. Colorado Outdoors $14(5): 31-33$.

Deutsch, H. F., and M. B. Goodloe. 1945. An electrophoretic survey of various animal plasmas. J. Bio. Chem. 1961:1-20.

Diesch, S. L., W. F. McCulloch, J. L. Braun, and J. R. Davis. 1970. Detection and ecology of leptospirosis in Iowa wildlife. J. Wildl. Dis. 6:275-288.

Dieterich, R. A. 1970. Hematologic values of some Arctic mammals. Am. Vet. Med. Assoc. 157(5):604-606.

Dikmans, G. 1939. Helminth parasites of North American semidomesticated and wild ruminants. Proc. Helminthol. Soc. Washington. $6(2): 97-101$.

- 1936. A note on Dictyocaulus from domestic and wild ruminants. J. Washington Acad. Sci. 26(7):298-303.

- 1931. Two new lung worms from North American ruminants and a note on the lungworms of sheep in the United States. Proc.

U. S. Nat. Mus. $79(18): 1-4$.

Dimopoullos, G. T. 1961. Polysaccharide and protein relationships of normal bovine serum. Am. J. Vet. Res. 22:986-989.

Dougherty, R. 1939. Sickle cells in the blood of western deer. J. Wild1. Manage. 3:17-18. 
Dukes, H. H. 1947. The physiology of domestic animals. Comstock Publishing Co., Inc., Ithaca, N. Y. 817pp.

Dunn, A. M. 1969. The wild ruminant as a host of helminth infection, pp. 221-248, In A. McDiarmid, ed. Diseases in free-living wild animals. Academic Press, New York, N. Yo 332pp.

Dunn, F. L. 1964. Erythrocyte sickling in the barking deer of Borneo. J. Mammal. 45(3):492-493.

Eggum, B. 0. 1970. Blcod urea measurement as a technique for assessing protein quality. Br. J. Nutr. 24:983-988.

Eveleth, D. F., and F. M. Bolin. 1955. Parasitic gastritis of elk. J. Wildl. Manage. 19(1): 152.

Ferris, D. H., L. E. Hanson, H. E. Rhoades, and J. O. Alberts. 1961. Bacteriologic and serologic Investigations of brucellosis and leptospirosis in Illinois deer. J. Am. Vet. Med. Assoc. $139: 892-896$.

Franzmann, A. W. 1972. Environmental sources of variation of bighorn sheep physiologic values. J. Wild1. Manage. 36(3):924-932.

- 1971. Comparative physiologic values in captive and wild bighorn sheep. J. Wildl. Dis. 7(2):105-108.

Franzmann, A. W., and E. T. Thorne. 1970. Physiologic values in wild bighorn sheep (Ovis canadensis canadensis) at capture, after handling, and after captivity. J. Am. Vet. Med. Assoc. $157(5): 647-650$.

Fujita, T. 1970. Delayed hypersensitivity reaction to succiny1choline. Tohoku J. Exp. Med. 102(1):33-35.

Garton, M. M., R. W. Menges, E. B. Shotts, A. I. Nahmias, and C. W. Heath. 1962. Leptospirosis -- epidemiology, clinical manifestations in man and animals, and methods in laboratory diagnosis. Public Health Service Pub1. No. 951. U. S. Gov. Printing Office, Washington, D. C. 70pp.

Giles, R. H., Jr., ed. 1969. Wildlife management techniques. The Wildlife Society, Washington, D. C. 623pp.

Graf, W. 1943. Natural history of the Roosevelt elk. Ph.D. Thesis. Oregon State Univ. 222pp. 
Graham, E. A., R. Rainey, R. E. Kuhlman, E. H. Houghton, and C. A. Moyer. 1962. Biochemical investigations of deer antler growth. Part I. Alterations of deer blood chemistry resulting from antlerogenesis. J. Bone and Joint Surg. 44-A:482-488.

Greer, K. R. 1965a. Collections from the Gardiner elk post season. Northern Yellowstone herd. P-R Compl. Rep., W-83-R-8, Montana Fish and Game Dept. 17pp. Multilith.

- 1965b. Collections from the Gallatin Elk post season, 1964-65. P-R Comp1. Rep., W-83-R-8. Montana Fish and Game Dept. 20pp. Multilith.

Greer, K. R., and H. Picton. 1964. Special collections, Yellowstone elk study, live blood analysis, minerals and vitamins. Montana Fish and Game Dept. P-R Compl. Rep., W-83-R-7. 7pp. Multilith.

Grobov, 0.F. 1961. On the susceptibility of elk to anaplasmosis of big-horned cattle. Veterinariya (Moscow) 9:50.

Gulliver, G. 1840. Observations on certain peculiarities of form In the blood corpuscles of the mammiferous animals. Proc. Zool. Soc. London 17:325-327.

Hal1, M. C. 1930. Parasites of elk and other wild ruminants. J. Washington Acad. Sci. 20(5):87-88.

Hammarsten, J. F., M. H. Welch, and C. A. Guenter. 1971. FamilizI lung disease and alpha 1 antitrypsin deficiency. Clin. Notes on Respiratory Dis. $9(4): 3-10$.

Hanson, R. P. 1961. Wild animal reservoirs and epidemiology . Wild1. Dis. No. 14. 13pp. Microcard.

Harper, J. A. 1966. Ecological study of Roosevelt elk. Oregon State Game Comm. Game Res. Rep. No. 1. P-R Proj. Rep., W-59-R. $29 \mathrm{pp}$.

Harthoorn, A. M. 1965. Application of pharmacological and physiological principles in restraint of wild animals. Wild1. Mono. No. 14. Wildlife Society, Washington, D. C. 78pp.

Herin, R. A. 1968. Physiological studies in the Rocky Mountain elk. J. Mammal. 49:762-764.

Herrick, J. B. 1910. Peculiar elongated and sickle shaped red blood corpuscles in a case of severe anemia. Arch. Int. Med. 6:517. 
Hodgs on, R. E., W. H. Ridde11, and J. S. Hughes. 1932. Factors influencing the blood-sugar level of dairy cattle. J. Agric. Res. $44(4): 357-365$.

Honess, R. F., and K. B. Winter. 1956, Diseases of wildlife in Wyoming. Wyoming Fish and Game Bull. No. 9. 279pp.

Horak, I., G. R. Clark, and J. Botha. 1965. The pathological physiology of helminth infestations. Onderstapoort J. Vet. Res. $32(1): 147-152$.

Houston, D. B. 1970. Immobilization of moose with M 99 Etorphine. J. Mammal. $51(2): 396-399$.

- 1969. A note on the blood chemistry of the Shiras moose. J. Mammal. $50(4): 826$.

Jansen, J., Jr. 1963. Some problems related to the parasite interrelationship of deer and domestic animals. Trans. Int. Union Game Bio. 6:127-132.

- 1960. Trichostrongylids in the fourth stomach of roe deer and red deer in the Netherlands. Trans. Int. Union of Game Bio. 4:91-95.

Jochim, M. M., T. L. Chow, 1969. Immunodiffusion of bluetongue virus. Am J. Vet. Res. $30(1): 33-41$.

Kaplan, H. M. 1954. Sex differences in the packed cell volume of vertebrate blood. Science 120:1044.

Karstad, L. 1969. Diseases of the Cervidae: bibliographic supplement I. Wildl. Dis. No. 52. 114pp. Microfiche.

- 1964. Diseases of the Cervidae: a partly annotated bibliography. Wild1. Dis. No. 43. 233pp. Microfiche.

Katz, J. S. 1941. Brucellosis in wildlife. Am Vet. Med. Assoc. J. $99(72): 25-27$.

King, J. M., and H. Klingel. 1965. The use of the Oripavine derivative $M 99$ for the restraint of equine animals, and its antagonism with the related compound $M$ 285. Res. Vet. Sci. $6: 447-455$.

Kitchen, H., and W. R. Pritchard. 1962. Physiology of blood. Proc. Nat. White-tailed Deer Dis. Symp. 1:109-114.

Kitchen, H., F. W. Putnam, and W. J. Taylor. 1967. Hemoglobin polymorphism in white-tailed deer; subunit bases. Blood $29(6)$; 867-877. 
Kitchen, H., F. W. Putnam, and W. J. Taylor. 1964. Hemoglobin polymorphism: its relation to sickling of erythrocytes in white-tailed deer. Science 144:1237-12.39.

Kitts, W. D., P. J. Bandy, A. J. Wood, and I. M. Cowan. 1956. Effect of age and plane of nutrition on the blood chemistry of the Columbian black-talled deer (Odocolleus hemionus columbianus). A. Packed-cell volume, sedimentation rate, and hemoglobin. Can. J. Zool. 34:477-484.

Knapp, S. E. 1968. A laboratory guide to parasitic diseases of domestic and game animals. Dept. of Veterinary Medicine, Oregon State Univ., Corvallis, Oreğon. 98pp. plus appendix.

Knight, R. R. 1969. Some chemical characteristics of elk blood. J. Wildl. Dis. 5:8-10.

Kocan, R. M. 1972. Some physiologic blood values of wild diving ducks. J. Wild1. Dis. 8(2):115-118.

Kuhlman, R. E., R. Rainey, and R. O'Neill. 1963. Biochemical investigations of deer antler growth. Part II. Quantitative microchemical changes associated with antler bone formation. J. Bone and Joint Surg. 45-A(2):345-350.

Kuttler, K. L., and D. W. Marble. 1960. Serum protein changes in lambs with naturally acquired nematode infections. Am. J. Vet. Res. 21:445-448.

- 1954. The effects of freezing and storage at $-20^{\circ} \mathrm{C}$ on serum protein patterns of sheep as determined by paper electrophoresis. Am. J. Vet. Res. 20:434-436.

Lanphear, P. R. 1962. Tranquilization and immobilization of wild animals. J. Am. Vet. Med. Assoc. 142(10):1126-1129.

Larson, B. L., and R. W. Touchberry. 1959. Blood serum protein level as a function of age. J. Anim. Sci. 18:989-990.

Leland, S. E., Jr. 1961. Blood and plasma volume, total serum protein, and electrophoretic studies in helminthic diseases. Annual N. Y. Acad. Sc1. 94(1):163-182.

Leland, S. E., Jr., J. H. Drudge, and R. P. Dillard. 1966. Influence of supertmposed nematode infection and grain supplement on some blood constituents of calves on pasture. Am. J. Vet. Res. 27(121): 1155-1165. 
Leland, S. E., Jr., J. H. Druge, and Z. N. Wyant. 1960. Studies on Trichostrongylus axei (Cobbold, 1879). VI. Total serum protein, blood and plasma volume, and electrophoretic serum fractionation in infected and uninfected lambs. Am J. Vet. Res. $21(82): 458-463$.

- 1959. Studies on Trichostrongylus axei (Cobbold, 1879). III. Blood and plasma volume, total serum protein, and electrophoretic serum fractionation in infected and uninfected calves. Exp. Parasito1. 8:383-412.

- 1958. Blood and plasma volume, total serum protein, and electrophoretic serum fractionations of calves experimentally infected with Trichostrongylus axei. J. Parasitol. Supp1. 44:27-28. Abstr.

LeResche, R. E., and J. I. Davis. 1971. Moose Research Rep. Alaska Dept. Fish and Game. P-R Proj. Rep., W-17-3. 156pp. Multilith.

Levine, N. D. 1968. Nematode parasites of domestic animals and of man. Burgess Publishing Co., Minneapolis, Minn. 600pp.

Lieberman, J., C. Mittman, and A. S. Schneider. 1969. Screening for homozgous and heterozygous alpha1-antitrypsin deficiency. J. Am. Med. Assoc. 210 (11):2055-2060.

Long, T. A., R. L. Cowan, C. W. Wolfe, T. Rader, and R. W. Swift. 1959. Effect of seasonal feed restriction on antler development of white-tailed deer. Pennsylvania Agric. Exp. Stn., Univ. Park Prog. Rep. No. 209:1-11.

Love, B. I. 1955. Personal observation in the care and management of an elk (wapiti) herd at Elk Island National Park, Alberta, Canada. Can. J. Comp. Med. 19(6):185-192.

Mace, R. U. 1971. Oregon's e1k. Wi1d1. Bu11. No. 4. Oregon State Game Comm. $29 \mathrm{pp}$.

Maloiy, G. M. O., R. N. B. Kay, and E. D. Goodall. 1968. Studies on the physiology of digestion and metabolism of the red deer (Cervus elaphus). Symp. Zool. Soc. London 21:101-108.

Mandery, J. H. 1960. The Olympic elk range, a seven year progress report. Washington Dept. of Fish and Game. 8pp. Mimeogr.

Matthews, P. J. 1968. Blood physiology of white-tailed deer on varying planes of nutrition. M. S. Thesis. Louisiana State Univ. 188pp. 
Mayrard, I. A., and J. K. Loos1i. 1969. Animal nutrition. McGrawHill Book Company, New York, N. Y. 613pp.

McBee, R. H. 1964. Rumen physiology and parasitology of the northern Yellowstone elk herd. Dept. of Bot. and Bacteriol. and Vet. Res. Lab. Montana State Uứiz., Būzemaan, Mont. 10pp.

McBee, R. H., and D. E. Worley, 1962. Physiology and parasitology of the Yellowstone Park elk, January, 1962, to June, 1964. Montana State Co11., Bozeman, Mont. 17pp.

McCandless, E. L., and J. A. Dye. 1950. Physiological changes in intermediary metabolism of various spectes of ruminants incident to functional development of rumen. Am. J. Physiol. 162: 434-446.

McDiarmid, A. 1969. Diseases in free-living wild animals. The Academic Press, New York, N. Y. 332pp.

McDougal1, E. I., and V. P. W. Lowe. 1968. Transferrin polymorphism and serum proteins of some British deer. J. Zool. London 155: $131-140$.

McEwan, E. H., and P. E. Whitehead. 1969. Changes in the blood constituents of reindeer and caribou occurring with age. Can. J. Zoo1. 47:557-562.

McGowan, J. E., L. Karstad, and N. A. Fish. 1963. Leptospirosis in Ontario Cervidae. Trans. 28th No. Am. Wiid1. Conf. 199-206.

Mckeever, S., G. W. Gorman, M. M. Galton, and A. D. Hall. 1958. The raccoon, Procyon lotor, a natural host of Leptospira autumnalis. Am. J. Hyg. 68:13-14.

Miller, W. J., A. O. Haugen, and D. J. Roslien. 1965. Natural variations in the blood proteins of white-tailed deer. J. Wildl. Manage. 29(4):717-723.

Mi11s, H. B. 1936. Observations on Yellowstone elk. J. Mamma1. $17(3)=250-253$.

Moore, D. H. 1945. Species differences in serum protein patterns. J. Bio. Chem. 161:21-32.

Moore, T. 1947. A survey of buffalo and elk herds to determine the extent of Brucella infection. Can. J. Comp. Med. and Vet. Sci. $11(5): 131$.

Morter, R. L., R. F. Langham, and E. V. Morse. 1958. Experimental leptospirosis. VI. Histopathology of the bovine placenta in Leptospira pomona infections. Am. J. Vet. Res. 19(73): 785-791. 
Murie, 0. J. 1951a. Distribution and numbers of wapiti. New

Zealand Dept. Sci. Indust. Res, Wellington Bul1. 103:17-21.

- 1951b. The elk of North America. The Stackpole Company, Harrisburg, Pa. 376pp.

- 1930. An ep̃izootic disease of elk. J. Mammal. 11(2):214-222.

Murphy, D. A., and J. A. Coates. 1966. Effects of dietary protein on deer. Trans. N. Am. Wild1. Nat. Resour. Conf. 31:129-139.

Murray, J. O., and D. O. Trainer. 1970. Bluetongue virus in North American elk. J. Wildl. Dis. 6:144-148.

Musacchia, X. J., C. G. Wilber, and T. W. Gorski. 1955. Hematological studies on mammals from Alaska. J. Mammal. 36(3):362-368.

Mylrea, P. J., and R. F. Bayfield. 1968. Concentrations of some components in the blood and serum of apparently healthy cattle. 1. Electrolytes and minerals. Aust. Vet. J. 44(12):565-569.

Mylrea, P. J., and P. J. Healy. 1968. Concentrations of some components in the blood and serum of apparently healthy dairy cattle. 2. Serum proteins, enzymes, bilirubin, and creatinine. Aust. Vet. J. 44(12):570-573.

Noyes, W. D., H. Kitchen, and W. J. Taylor. 1966. Red cell life of white-tailed deer Odocoileus virginianus. Comp. Biochem. Physiol. 19:471-473.

Olbrich, S. E., F. A. Martz, M. E. Tumbleson, H. D. Johnson, and E. S. Hilderbrand. 1971. Serum biochemical and hematological measurements of heat tolerant ( $\mathrm{Zebu}$ ) and cold tolerant (Scotch Highland) heifers. J. Anim. Sci. 33(3):655-658.

O'Roke, E. C. 1936. Sickle cell anemia in deer. Proc. Soc. Bio. Med. 34: 738-739.

Orr, R. T. 1937. Notes on the 1ife history of the Roosevelt elk in California. J. Mammal. 18(1):62-66.

Payne, J. A., G. D. Martin, J. D. Story, and G. E. Cosgrove. 1967. Electrophoresis as an aid in detecting pathological conditions in wild mammals. J. Wildl. Dis. 3:21-22.

Petrusewicz, K. 1967. Secondary productivity of terrestrial ecosystems. Principles and methods. Vol. 1. Int. Bio. Program. Warsaw, Poland. 379pp. 
Planas, J., and M. Grau. 1971. Serum chemistry in the chimpanzee and gorilla. Folia Primat. 15:77-87.

Polson, A. 1943. Variation of serum composition with the age of horses as shown by electrophoresis. Nature 152:413-414.

Post, G. 1957. Clinical studies in elk nutrition. Wyoming Game and Fish Comm. Job Comp1. Rep. Proj. No. FW-3-R-4. 23pp.

- 1953. To establish normal blood constituents of deer, elk and antelope. Wyoming Game and Fish Comm., Wilil. Dis. Lab., Laramie, Wyoming. Job Comp1. Rep. Proj. No. W-27-R-5. 103pp.

Poynter, D., and S. Selway. 1966. Diseases caused by lungworms. Helminthol. Abstr. 35(2): 105-127.

Prasse, K. W. 1969. Lactic dehydrogenase activity and isoenzyme distribution in serum of normal cattle. Am. J. Vet. Res. $30(12): 2181-2183$.

Presidente, P. J. A., D. E. Worley, and J. E. Catlin. 1972. Croastransmission experiments with Dictyocaulus viviparus isolates from Rocky Mountain elk and cattle. Wild1. Dis. 8:57-62.

Preston, R. L., D. D. Schnakenberg, and W. H. Pfander. 1965. Protein utilization in ruminants. I. Blood urea nitrogen as affected by protein intake. J. Nutr. $86(3): 281-288$.

Prestwood, A. K., J. F. Smith, and J. Brown. 1971. Lungworms in white-tailed deer of the southeastern United States. J. Wild1. Dis. 7:149-154.

Quimby, D. C. and J. E. Gaab. 1957. Mandibular dentition as an age Indicator in Rocky Mountain elk. J. Wildl. Manage. $21: 435-451$.

Reilly, J. R. 1970. The susceptibility of five species of wild animals to experimental infection with Leptospira grippotyphosa. J. Wildl. Dis. 6:289-294.

Reilly, J. R., T. F. Muraschi, and D. J. Dean. 1962. Experimental Leptospira pomona infection in white-tailed deer, odocoileus virginianus, and in cattle. J. Am. Vet. Med. Assoc. $140(1): 53-57$.

- 1961. Leptospirosis in the white-tailed deer, Odocolleus virginianus. Cornel1 Vet. 52(1):94-98.

Reinhard, K. R. 1954. Public health aspects of animal leptospirosis. Proc. Am. Vet. Med. Assoc. 91:455-460. 
Riegle, G. D., and J. E. Nellor. 1966. Changes in blood cellular and protein components during ageing. J. Geront. 21:435-438.

Rosen, M. N., and A. I. Bischoff. 1952. The relation of hematology to condition in California deer. Trans. N. Am. Wildl. Conf. $17: 483-496$.

Roth, E. E. 1964. Leptospirosis in wildlife in the United States. Proc. Am. Vet. Med. Assoc. Proc. 10lst Ann. Meeting 211-218.

Roussel, J. E., and 0. T. Stallcup. 1966. Influence of age and season on phosphatase and transaminase activities in blood serum of bulls. Am. J. Vet. Res. 27(121):1527-1529.

Rush, W. M. 1933. Relation of heavy use of range to spread of parasites and diseases in animals. Northern Yellowstone elk study. Montana Fish and Game Comm. Missoula, Montana. 131pp.

- 1932. Bang's disease in the Yellowstone National Park buffalo and elk herds. J. Mammal. 13:37i-372.

Samuel, W. M., and R. L. Beaudoin. 1966. Evaluations of two survey methods for detection of helminth infections in white-tailed deer (Odocoileus virginianus). J. Wild1. Dis. 2:100-107.

- 1965. Identification of eggs and larvae of nematodes parasitic in deer in Pennsylvania. Proc. Pennsylvanta Acad. Sci. $39: 73-77$.

Samue1, W. M., and D. O. Trainer. 1968. Trichostongylus axei (Cobbold, 1879) in white-tailed deer. J. Paras1tol. 54:1091.

Schalm, 0. W. 1965. Veterinary hematology. 2nd ed. Lea and Febriger, Philadelphia, Pa. 664pp.

Schwartz, J. E. 1943. Range conditions and management of the Roosevelt elk on the Olympic Peninsula. U. S. Dept. of Agric., Forest Service. N. Pac. Region. 65pp. Mimeogr.

Schwartz, J. E., and G. E. Mitche11. 1945. The Roosevelt elk on the Olympic Peninsula, Washington. J. Wildl. Manage. $9(4): 295-319$.

Sea1, U. S., and A. W. Erickson. 1969a. Immobilization of Carnivora and other mammals with phencyclidine and promazine. Fed. Proc., Anesthesia in Lab. Anim. 28(4):1410-1419.

- 1969b. Hematology, blood chemistry, and protein polymorphisms in the white-tailed deer (0docoileus virginianus).

Comp. Biochem. Physiol., 30:695-713. 
Sea1, U. S., J. J. Ozaga, A. W. Erickson, and L. J. Verme. 1972a. Effects of immobilization on blood analyses of white-tailed deer. J. Wild1. Manage. 36:1034-1040.

Seal, U. S., L. J. Verme, J. J. Ozaga, and A. W. Erickson. $1972 \mathrm{~b}$. Nutritional effects on thyroid activity and blood of whitetailed deer. J. Wild1. Manage. 36:1041-1052.

Shaw, J. N. 1947. Some parasites of Oregon wild 1ife. Oregon Agric. Stin. Bull. 11. 16pp.

Shive, R. J., S. S. Green, L. B. Evans, F. M. Garner. 1969. Leptospirosis in Barbary apes (Macaca sylvana). J. Am. Vet. Med. Assoc. $155(7): 1176-1178$.

Shorb, D. A. 1940. A comparative study of the eggs of various species of nematodes parasitic in domestic ruminants. J. Parasitol. 26:233-231.

Shotts, E. B., W. E. Greer, and F. A. Hayes. 1958. Preliminary survey of the incidence of brucellosis and leptospirosis among white-tailed deer of the sourtheast. J. Am. Vet. Med. Assoc. 133: 359-361.

Sikes, D., T. P. Kistner, J. H. Eve, and F. A. Hayes. 1972. E1ectrophoretic distribution and serologic changes of blood serum oi arthritic (rheumatoid) white-tailed deer infected with Erysipelothrix insidiosa. Am. J. Vet. Res. 33(12):2545-2.549.

Skrjabin, K. I., M. P. Shikhobalova, and R. S. Shul ts. 1960. Essentials of nematodology. Vo1. 3. Trichostrongylids of animals and man. English trans1. U. S. Dept. of Commerce, Washington, D. C. 704pp.

Sleight, S. D., and J. A. Williams. 1961. Transmission of bovine leptospirosts by coition and artificial insemination. J. Aill. Vet. Med. Assoc. 138:151-152.

Sloan, J. E. N. 1965. Helminthiases in ungulates. The International Zoo Yearbook 5:24-28.

Sloss, M. W. 1970. Veterinary clinical parasitology. The Iowa State Univ. Press, Ames, Iowa. 250pp.

Smith, H. A., and T. C. Jones. 1947. Veterinary pathology. Lea and Febriger, Philadelphia, Pa. 959pp.

Snedecor, G. W., and W. G. Cochran. 1968. Statistical methods. Iowa State Univ. Press, Ames, Iowa. 953pp. 
Soulsby, E. J. L. 1969. Helminths, arthropods and protozoa of domesticated animals, (6th edition of Monnig's veterinary helminthology and entomology). Baillier, Tindall and Casse11, London. 824pp.

Stauber, L. A. 1954. Application of electrophoretic techniques in the field of parasitic diseases. Exp. Parasitol. 3:544-568.

Swales, W. E. 1935. The life cycle of Fasciolotdes magna (Bassi, 1875), the large liver fluke of ruminants, in Canada. Can. J. Res. 12:177-215.

Teeri, A. E., W. Virchow, J. F. Colovos, and F. Greeley. 1958. Blood composition of white-tailed deer. J. Mammal. 39:269-274.

Thomas, F. C., and D. O. Trainer. 1970a. Bluetongue virus in whitetailed deer. Am. J. Vet. Res. 31:271-278.

- 1970b. Bluetongue virus: (1) in pregnant white-tailed deer (2) a plaque reduction neutralization test. J. Wildl. Dis. $6: 384-388$.

Trainer, C. E. 1969. Roosevelt elk fertility study. Oregon State Game Comm. Game Res. Rep. 25pp.

Trainer, D. 0. 1967. The relationship of infectious disease to animal behavior. Trans. N. Am. Wildl. Nat. Resour. Conf. $32: 374-381$.

Trainer, D. O., and R. P. Hanson. 1969. Serologic evidence of arbovirus infections in wild ruminants. Am. J. Epidemiology $90: 354-358$.

Trainer, D. O., and M. M. Jochim. 1969. Serologic evidence of bluetongue in wild ruminants of North America. Am. J. Vet. Res. $30(11): 2007-2011$.

Trainer, D. O., L. H. Karstad, and R. P. Hanson. 1961. Experimental leptospirosis in white-talled deer. J. Infect. Dis. 108: 278-286.

Trainer, D. O., R. P. Hanson, E. P. Pope, and E. A. Caxbrey. 1963. The role of deer in the eipzootiology of leptospirosis in Wis consin. Am. J. Vet. Res. 24(98):159-167.

Troyer, W. A. 1960. The Roosevelt elk on Afognak Island, Alaska. J. Wildl. Manage. 24(1):15-21.

Tumbleson, M. E. 1969. Modification of the Sequential Multiple Auto-Analyzer (SMA-12/30) for use in animal research studies. Clin. Biochem. 2:357-367. 
Tumbleson, M. E., and D. P. Hutcheson. 1971. Âge related serum cholesterol, glucose, and total bilirubin concentrations of female dairy cattle. Proc. Soc. Exp. B1o. Med. 138(3):1083-1085.

Tumbleson, M. E., and H. D. Johnson. 1969. The use of animals as biomedical research subjects for aging studies. Advan. in Auto. Analysis/Biomedical Profiling 3:117-125.

Tumbleson, M. E., M. F. Burks, and W. E. Wingfield. 1973a. Serum protein concentrations, as a function of age, in female dairy cattle. Aging and serum proteins. Cornel1 Vet. 63(1):65-71.

Tumblesons M. E., J. D. Cuneio, and D. A. Murphy. 1970a. Serum biochemical and hematological parameters of captive whitetalled fawns. Can. J. Comp. Med. 34(1):66-71.

Tumbleson, M. E., C. C. Middleton, and J. D. Wallach. 1970b. Serum biochemic and hematologic parameters of adult aoudads (Ammotragus lervia) in captivity. Am. Assoc. for Lab. Anim. Sci. $20(2): 242-245$.

Tumbleson, M. E., M. G. Wood, and C. C. Middleton. 1968a. The study of aging in animals using automated clinical chemistry. 1967 Technicon Symposia. Mediad, White Plains, N. Y. pp.515-517.

Tumbleson, M. E., J. W. Ticer, A. R. Dommert, D. A. Murphy, and L. J. Korschgen. 1968b. Serum proteins in white-talled deer in Missouri. Am. J. Vet. Clin. Path. 2:127-131.

Tumbleson, M. E., W. E. Wingfield, H. D. Jonson, J. R. Campbell, and C. C. Middleton. 1973b. Serum electrolyte concentrations, as a function of age, in female dairy cattle. Aging and serum electrolytes. Cornell Vet. 63(1):58-64.

Tumbleson, M. E., M. G. Wood, A. R. Dommert, D. A. Murphy, and L. J. Korschgen. 1968c. Blochemic studias on serum from white-tailed deer in Missourf. Am. J. Vet. Clin. Path. $2: 121-125$.

Tunnicliff, E. A., and H. Marsh. 1935. Bang's disease in bison and elk in the Yellowstone National Park and on the National Bison Range. J. Am. Vet. Med. Assoc. 86:745-752.

Turner, J. H., and G. I. Wilson. 1962. Serum protein studies on sheep and goats. I. Studies on Shropshire lambs exposed to different degrees of parasitism. Am. J. Vet. Res. 23:718-724.

Turner, L. H. 1968. Leptospirosis. II. Serology, Trans. R. Soc. Trop. Med. Hyg. 62(6): 880-899. 
Twigg, G. I., C. M. Cuerden, and D. M. Hughes. 1968. Leptospirosis in British wild mammals. Proc. Symp. Zool. Soc. London 24:75-98.

Undritz, E., K. Betke, and H. Lehman. 1960. Sickling phenomenon in deer. Nature 187:333--334.

Van Cleve, H. J. 1937. Worm parasites in their relation to wildlife investigations. J. Wildl. Manage. 1(1):21-27.

Van Tets, P., and I. M. Cowan. 1966. Some sources of variation in the biood sera of deer (Odocoileus) as revealed by starch get electrophoresis. Can. J. Zoo1. 44:631-647.

Van Volkenberg, J. L., and A. J. Nicholson. 1943. Parasitism and malnutrition of deer in Texas. J. Wild1. Manage. $7(2): 220-223$.

Vosdingh, R. A., D. O. Tralner, and B. C. Eaterday. 1968. Experimental bluetongue disease in white-tailed deer. Can. J. Comp. Med. Vet. Sc1. 32:382-387.

Walker, M. L., and W. W. Becklund. 1970. Index-catalogue of medical and veterinary zoology. Spec. Pub. No. 1. Checklist of the internal and external parasites of deer, Odocolleus hemionus and $\underline{0}$. virginianus, in the U. S. and Canada. U. S. Dept. of Agric. 45pp.

Weber, Y. B., and M. L. Bliss. 1972. Blood chemistry of Roosevelt elk (Cervus canadensis roosevelti). Comp. Biochem. Physiol. 43A:649-653.

Weber, Y. B., and L. Giacometti. 1972. Sickling phenomenon in the erythrocytes of wapiti (Cervus canadensis). J. Mammal. $53(4): 917-919$.

Whanger, P. D., P. H. Weswī, O. H. Muth, and J. F. O1dfield. 1969 . Tissue lactic dehydrogenase, glutamic-oxalacetic transaminase, and peroxidase changes of selentum-deficient myopathic lambs. J. Nutr. 99:331-337.

White, C. M. 1967. A device for immobllizing trapped deer. J. Wildl. Manage. 31(4):844-845.

White, R. R., K. R. Christian, and V. J. Williams. 1948. Blood chemistry and haematology in sheep on decreasing levels of feed intake followed by starvation. New Zealand J. Sci. Tech. $38(4): 440-448$. 
Whitehead, P. E. 1962. Some factors influencing the level of reducing sugar in the blood of black-tailed deer. M. S. Thesis. Univ. British Columbia. 73pp.

Whitlock, J. 1949. The relation of nutrition to the development of trichostrongylidoses. Cornell Vet. 39(2):146-182.

Whitlock, S. C. iy 39 . Studies on the blood of white-tailed deer. J. Wildl. Manage. 3(1):14-16.

Wilbur, C. G., and P. F. Robinson. 1958. Aspects of blood chemistry in the white-tailed deer. J. Mammal. $39(2): 309-311$.

Wilson, G. I. 1969. Some parasites of elk in New Mexico. J. Wild1. Dis. 5(1):23-24.

Wingfield, W. E., and M. E. Tumbleson. 1973. Hematologic parameters, as a function of age, in female dairy cattle. Aging and hematologic values. Cornell Vet. 63(i):72-80.

Wintrobe, M. M. 1933. Variations in the size and hemoglobin content of the blood of various vertebrates. Folia Haematologica. $51: 32-49$.

Wise, M. B., A. L. Ordoveza, and E. R. Barrick. 1963. Influence of variations in dietary calcium: phosphorus ratio on performance and blood constituents of calves. J. Nutx. 79(1):79-84.

Wise, M. B., S. E. Smith, and L. L. Barnes. 1958. The phosphorus requirement of calves. J. Anim. Sci. 17(1):89.99.

Wolff, W. A., M. E. Tumbleson, and C. A. Littleton. 1969. Serum chemistry in normal and diseased nuises. Advan. In Auto. Analysis/Biomedical Profiling 3:179-185.

Woolf, A., and D. C. Kradel. 1970. Hematological values of captive Rocky Mountain bighorns. J. Wildl. Dis. 6:67-68.

Woolf, A., C. F. Nadler, and D. C. Kradel. 1973. Serum protein electrophoresis in bighorn sheep with chronic pneumonia. J. Wild1. Dis. 9(1):7-11.

World Health Organization. 1967. Current problems in leptospirosis research. Tech. Rep. Series No. 380. Geneva. 32pp.

Worley, D. E., and G. A. M. Sharman. 1966. Gastritis associated with Ostertagia bisonis in Montana range cattle. J. Am. Vet. Med. Assoc. 149 (10):1291-1294. 
Worley, D. E., R. E. Barrett, P. J. A. Presidente, and R. H. Jacobson. 1969. The Rocky Mountain elk as a reservoir for parasites of domestic animals in western Montana. J. Wildl. Dis. $5: 348-350$.

Youatt, W. G., and L. D. Fay. 1959. Experimental brucellosis in white-tailed deer. Am. J. Vet. Res. 20(78):925-926.

Youatt, W. G., L. J. Verme, and D. E. U11rey. 1965. Composition of milk and blood in nursing white-tailed does and blood composition of their fawns. J. Wildl. Manage. $29(1): 79-84$.

Youatt, W. G., L. D. Fay, D. L. Howe and H. D. Harte. 1961. Hematologic data on some small mammals. Blood 18:758-763.

Youatt, W. G., L. D. Fay, G. L. Whitehead, and J. P. Newman. 1959. Brucellosis and leptospirosis in white-tailed deer in Michigan. J. Wildl. Manage. 23:345-348. 
APPENDIX A

DIRECTIONS FOR OBTAINING BLOOD SAYPLES

At the time the animal is imobilized, record the following information:

$\begin{array}{lc}1 \text { - Date } & 6 \text { - Sex } \\ 2 \text { - Species } & 7 \text { - Age } \\ 3 \text { - Drug } & 8 \text { - WeIght } \\ 4 \text { - Amount } & 9 \text { - B lologlot } \\ 5 \text { - Area } & 10 \text { - ID Number }\end{array}$

Keep animal's head turned uph111. Draw blood from external jugular vein found by palpating neck. To obtain samples for serum, use flexible blood donor tube set. Insert long needle into vein. Make sure blue clamp is off and blood is flowing through tube. Insert small needle at end through rubber top of brown stoppered vacutainer tube and fill. Without removing blood donor set from animal's vein, change to fill a second brown stoppered tube. Between tube changes, do not stop blood flow in donor set. These large samples will be allowed to clot and be centrifuged, for serum.

To obtain uncoagulated whole blood sample, again without removing blood donor set from animal's vein, fill purple stoppered small vacutainer tube. After f1111ng tube fully to top, withoraw needle, then shake tube back and forth gently to mix in the dry anticoagulant already in tube. This small sample will be uged for hemoglobin and packed cell volume (hematocrit) determinations, and for complete blood counts.

Last, using one drop from small needle, make blood sweass on frosted end glass slides. Do not use blood donor set on more than one antmal. Should the blood donor set cease to flow, withdraw needle from animal's neck and start over with new blood donor set. If at all possible, blood sildes should be made in the field at the time the samples are drawn, using drops from the tip of the needle. If the blologist does not make slides then, use of uncoagulated sample later 18 a less desirable alternative. Do within 8 hours.

Label both tubes with ID number of animal and mark frosted end of glass sildes. Enclose ice pillows but not dry 1ce. Ship as directed, to be received within thirtysix hours. 
APPENDIX B

DIRECTIONS FOR COLLECTING ELK ORGANS

COLLECT INTESTINES AND LUNGS. IF HUNTER IS NOT KEEPING LIVER AND HEART, COLLECT THOSE ORGANS, TOO.

COLLECT ONLY ORGANS FROM ANIMALS RILLED THAT SAME DAY.

IF POSSIBLE, GET ONE ENTIRE FRONT TOOTH. A POCKET KNIFE BETWEEN TWO TEETH

WILL HELP LOOSEN.

USE TWO OF THE PLASTIC BAGS SUPPLIED, ONE INSIDE THE OTHER, TOR STRENGTH

ON LABEL, ATTACHED BY WIRES TO NECK OF BAG, RECORD:

AGE

$\operatorname{SEX}$

WEIGHT

WHERE RILLED

RARE OF COLLECTOR

DATE

YOUR BEST ESTIMATE ON ABOVE DATA WILL DO. IF YOU'D PRETER, DESCRIBE THE ANTLERS RATHER THAN GUESS AGE.

ARRANGEMENTS HAVE BEEN MADE FOR FREEZING BAGS AT REED AND HERTIG, WARRENTON, BETWEEN 8 A.M. AND 6 P.M. THEY WILL BE OPEN SATURDAY THE 1.3TH AND SUNDAY THE 14TH. BAGS MAY ALSO BE DROPPED OFF AT JEWELL MEADONS WILDLIFE REFUGE. PLFASE RADIO THE OREGON STATE HIGHWAY POLICE OFFICE AT ASTORIA WHEN YOU'VE COLLECTED A SAMPLE. DURING THE MIDDLE OF THE HEEK, I CAN MEET YOU TC GET THE RAGS. THANK YOU VERY MUCH FOR YOUR HELP.

YVONNE B. WEBER

OREGON 2OOLOFY RESEARCH CENTER

PORTLAND, OREGON 


\author{
APPENDIX $C$ \\ METHODS OF CHEMICAL ANALYSIS UTILIZED \\ BY THE \\ TECHNICON SMA AUTOANALYZER
}

\title{
Total Protein
}

This procedure is the standard AutoAnalyzer Method, which uses a modified Biuret reaction described by J. F. Faliing, M. W. Buckley, and B. Zack, Am. I. Clin. Path. 33:83-88 (1960). Copper, in alkaline solution, forms a purple complex with the peptide linkages of amino acids in protein. The protein stream is mixed with the Biuret reagent and the developed color is measured at $550 \mathrm{~nm}$.

The serum blank is determined by diluting the sample with alkaline lodide solution and measuring the absorption at $550 \mathrm{~nm}$. The blank is automatically subtracted by differential colorimetry. Sodium and Potassium

Sodium and potassium are assayed simultaneously by standard flame photometric methods using lithium sulfate as an internal standard.

\section{Calcium}

This procedure is a modification of the method of $G$. Kessler and ii. Wolfman, Clin. Chem. 10:686 (1964). The new method, as reported by H. Gitelman, Anal. Biochem. 18:521 (1967), incorporates the use of 8hydroxyquinoline to substantially reduce magnesium interference.

The diluted serum sample is mixed with $0.3 \mathrm{~N}$ hydrochloric acid containing 8-hydroxyquinoline, to release protein-bound calcium and combine with the magnesium. Then it is dialyzed into a recipient stream of cresolphthalein complexone, again containing 8-hydroxycuinoline. A 
colored complex between calcium and dye is formed upon the addition of diethylamine. The color developed is measured at $570 \mathrm{~nm}$. Inorganic Phosphate

This is a modification of the standard method, based on the formation of phosphomolybdic acid, which is then reduced by stannous chloridehydrazine, The use of this more stable reducing agent was first reported by R. O. Hurst, Can. J. Biochem. 42:287 (1964) and adapted to the AutoAnalyzer by M. Kram1, C1in. Chim. Acta 13:442 (1966).

Serum is mixed with, and also dialyzed against, $1 \% \mathrm{H}_{2} \mathrm{SO}_{4}$. The dialyzable phosphate is then mixed with an acidic solution of ammonium molybdate with the formation of phosphomolybdic acid, which is immediately reduced by stannous chloride-hydrazine. The absorption of the blue product is measured at $660 \mathrm{~nm}$.

Blood Urea Nitrogen (BUN)

The method modified that of Marsh et al., Clin. Cuem. 11:624 (1965). A colored product is formed when urea, in relatively weak acid solution, reacts with diacetyl monoxime. The presence of thiosenicarbazide and ferric ion intensifies the color of the reaction. The mixture is heated at $90^{\circ} \mathrm{C}$ for color develüpment, and reaá at $520 \mathrm{~nm}$.

Chloride

The method is that of L. Skeggs, Jr. and H. Hochstrasser, Clin. Chem. 10:918 (1964). Chloride forms a soluble, nonionized compound with mercury. Reacting chloride with mercuric thiocyanate releases the radical (SCN), which is reacted with ferric lons to form the red complex, $\mathrm{Fe}(\mathrm{SCN})_{3} \cdot$ The absorbance of this complex is measured at $480 \mathrm{~nm}$. 
Cholestero1

This method is based on a modification by Huang et al., Anal. Chem. 33:1405 (1961) of the Lieberman-Burchard method for use in the direct determination of serum cholesterol. Diluted seruil is mixed with a stable reagent composed of acetic acid, acetic anhydride, and sulfuric acid. The developed color is read at $630 \mathrm{~nm}$.

Glucose

The SMA AutoAnalyzer employs either of two methods for assaying glucose: neocuproine or glucose oxidase. The neocuproine method used in my study is a modification of the procedures of M. Brown, Diabetes 10:60 (1961), and D. Bittner and M. McCleary, Am. J. Clin. Path. 40-423 (1963). A cupric-neocuproine chelate is reduced by glucose in an alkaline medium, resulting in a highly-colored, cuprous-neocuproine compiex. Affter heating at $90^{\circ} \mathrm{C}$, the ahsorbance is mossured at $46 \mathrm{C} \mathrm{nm}$. Interference due to ascorbic acid and sulfhydryl groups is reduced by treating the dialysate with sodium carbonate before addition of the color reagent.

Total and Direct Bilirubin

The method for total and direct bilirubin is based on the procer dure of L. Jendrassik and P. Grof, Biochem. Z. 297:81 (1938), as adapted by S. Gambino and H. Schreiber, Automation in Analytical Chemi-

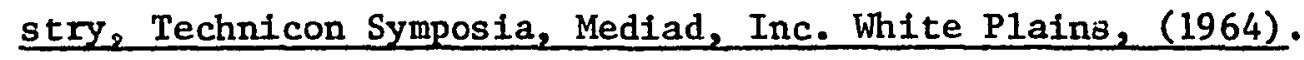

Total bilirubin (free and conjugated) is reacted with diazotized sulfanilic acid in the presence of a caffeine-sodium benzoate "accelerator" reagent to form colored azobilirubin. Sodium potassium tartrate is added to raise the $\mathrm{pH}$ and shift the wavelength of the reaction pro- 
duct. The absorbance of the alkaline azobilirubin is measured at $600 \mathrm{~nm}$.

Since free bilirubin is insoluble in water below $\mathrm{pH} 8$, direct (or conjugated) bilirubin is determined by reacting samples with diazotized sulfanilic acid (diazo reagent) in an acidic aqueous medium. The direct reaction is time dependent and is stopped after two minutes by the addition of ascorbic acid, which inactivates the diazo reagent.

The serum blank is determined by mixing the sample stream with caffeine, sulfanilic acid (replacing the diazo reagent), and tartrate. The absorbance in the blank stream is measured at $600 \mathrm{~nm}$. Both total and direct bilirubin samples share a common blank, which is automatically subtracted by differential colorimetry.

\section{Creatinine}

The analytical procedure for creatinine is based on the reaction between alkaline picrate and creatinine (Jaffe reaction). The sample stream, segmented with air, is diluted with $1.8 \%$ sodium chloride and dialyzed against water segmented with air. After dialysis, the analytical stream is mixed with $0.5 \mathrm{~N} \mathrm{NaOH}$ and then with saturaied picric acid. Absorbance is measured at $505 \mathrm{~nm}$.

Uric Ac1d

This procedure for the measurement of uric acid is based on the reduction of a phosphotungstate complex to a phosphotungstite complex. Sodfum tungstate is used as a stable alkalizing agent and hydroxylamine intensifies the color. The method is based on the work of A. Musser and C. Ortigoza, Tech. Bull. of the Reg. of Med. Tech. 36:21 (1966), who autouited the ortginal procedure of M. Simoes Sobrinho, J. Lab. Clin. Med. 65:665 (1965). Serum is diluted with normal saline, neutralized, 
and then dialyzed against a sodium tungstate-hydroxylamine solution. Phosphotungstic acid is added and the color produced is measured at $660 \mathrm{~nm}$.

Alkaline Phosphatase

This is the method of Morgenstern et al., Clin. Chem. 11:876, (1965), which is a modification of the procedure of Bessey et al., J. Biol. Chem. 16 ás:321 (1964). The procedure is based on the enzymatic hydrolysis of p-nftrophenyl phosphate during incubation at $37^{\circ} \mathrm{C}$. Following incubation, the free p-nitrophenol is dialyzed into a 2-amino-2methy1-1-propanol recipent buffer. The dialyzed p-nitrophol is highly colored under alkaline conditions and thereby provides its own chromagen. Dialysis eliminates the interference of bilirubin and the need for blank correction. The absorbance of p-nitrophenol is measured at 410 nm.

Lactic Dehydrogenase (LDH)/340 nm

The automated procedure for the detarmination of $L D H$ is based on the procedure of Morgenstern et al., Anal. Biochem. 13:149 (1965). Lactic dehydrogenase catalyzes the oxidation of lactate to pyruvate in the presence of NAD. The reaction is as follows:

Lactate + NAD (nonausorbent) LDH Pyruvate + NADH (abosrbent)

The NADH produced is proportional to the enzymatic activity, and is measured at $340 \mathrm{~nm}$.

Serum Glutamic Oxalacetic Transaminase (SGOT)/340 nm

The automated photometric $(340 \mathrm{~nm})$ procedure for the determination of SGOT was described by R. L. Rush et al., at: the American Association of Clinical Chemists meeting in Buffalo, 1970. It is an adaptation of 
the automated fluoromet:ric procedure of $\mathrm{J}$. B. Levine and J.B. Hill as reported in Automation in Analyticai Chemistry, Technicon Symposia, Mediad, Inc., White P1ains (1965).

This spectrophotometric procedure measures the change in absorbance of NADH (DPNH) a.t $340 \mathrm{~nm}$. The test is comprised of two separate reactions.

First, the serun is diluted with substrate and incubated at $37.5^{\circ} \mathrm{C}$ for approximately $5_{\frac{1}{2}}^{1}$ ifnutes to produce the fullowing reaction:

Aspartic Acid + Alpha-Ketoglutaric Acid SGOT,Oxalacetic Acid + Glutamic AcId

In this reaction, the concentration of products formed in a given period of time is froportional to the SGOT activity in the serum. Second, the proliuts dlalyze through the dialyzer membrane and the oxalacetate :eenct 3 with $\mathrm{NADH}$ in the presence of the enzyme malate dehydrogenase (MDEl) $t:$ form malate. The reaction is as follows:

Oxalacetate + NiDH (absorbent) $\mathrm{MDH}$ Malate + NAH (non-absorbent) Absorbance of $\mathrm{NA}, \mathrm{DH}$ is measured at $340 \mathrm{~nm}$. 